\title{
COHORT ANALYSIS OF CANCER MORTALITY IN ENGLAND AND WALES, 1911-1954 BY SITE AND SEX
}

\author{
BY \\ R. A. M. CASE \\ From the Chester Beatty Research Institute, Institute of Cancer Research, Royal Cancer Hospital, London
}

\section{INTRODUCTION}

Considerable confusion seems to exist amongst both medical and lay people about current trends of cancer mortality. This is hardly diminished by Raven (1955) when he confuses number and rate so much that he follows his statement "It is frequently asked whether or not the death-rate from cancer is increasing" by quoting the number of deaths from cancer during the years 1943 to 1953 and commenting "The figures show the steady increase in the death-rate from cancer in this ten-year period." [Italics inserted]. It therefore seems an appropriate time to use the narrative technique of cohort analysis to show what has happened to the mortality rates, male and female, in England and Wales since 1911.

A few authors have already published cohort studies on some aspect of mortality or morbidity from cancer of the lung (Korteweg, 1951, 1953; Clemmesen, Nielsen, and Jensen, 1953; Levin, 1953; Stocks, 1953a; Cutler and Loveland, 1954; Haenszael and Shimkin, 1956). Cohort analysis is mentioned by Dorn (1953) and a diagram of cohort analysis of male mortality from cancer of the lung in England and Wales is given without comment or description by Kennaway and Waller (1953). Stocks $(1953 a, b)$ also shows cohort analysis figures for cancer of the female breast, the uterus, and the stomach, but obscures for many readers the narrative properties of the method by using a semilogarithmic plot. Hewitt (1955) analyses leukemia mortality by the cohort method.

No author seems to have attempted a systematic survey of cancer by site for any country, and none of the authors cited has given sufficient description of the principles involved in the method either to enable the non-statistical reader to follow it readily or to convince the methodologist of the validity of its logical credentials. This has been attempted in a previous paper (Case, 1956).
The present studies attempt in general to outline the changes that have taken place in cancer mortality in England and Wales for 21 different sites of cancer in the last 45 years, and in particular to answer three questions, posed in a biological form, because they still seem to be of great interest to many workers in the field of cancer research as well as to clinicians.

These questions are:

(1) Is the lethal force with which cancer affects the community increasing and if so what forms of cancer contribute to this increase?

(2) Is there, generally speaking, a "cancer-age" or does the force of mortality due to cancer at different sites increase throughout the life span?

(3) Is there a consistent sex-difference in the force of mortality due to cancer at the different sites that are common to both sexes, and if so how great is this difference?

No claim is made that these questions are not answered elsewhere, or that they could not be answered by some other method of analysis, although the author believes that no other method has answered them in a way so readily understood by readers with a modicum of biological insight but no special statistical knowledge.

The studies will immediately suggest many other questions to which no answer has been hazarded. This is because the results of cohort analysis are only one component of the synthesis of knowledge required for answering such questions. This topic has been discussed more fully elsewhere (Case, 1956).

\section{Materials AND Methods}

The previous paper has explained how the essential feature of cohort analysis is that it follows the mortality rate of a population defined by its birth years throughout the lifetime of the surviving portion of that population, thus offering some chance of distinguishing between the 
effects of nature and of nurture on the death rates, and also making it possible to correlate the changes in the death rates with the social history of the period.

In order to provide sensitive and comprehensive methods for detection of environmental cancer risks, Case and Pearson (1955) had undertaken firstly a concordance of the Cancer Mortality Tables given in the "Annual Reports of the Registrar-General" (1911-20) and the "Registrar-General's Statistical Reviews of England and Wales" (1921-54), and secondly the systematic calculation of age-specific death rates for cancer at 21 different sites for each sex in quinaryquinquennial groups from 1911 onwards. Similar Mortality Tables were computed for All Causes of Death; Leukaemia; Hodgkin's Disease; Benign Tumours and Tumours of Undetermined Nature; and Cancer at All Sites. A further Table for cancer at sites other than the 21 specified ones was obtained by difference.

Many of the source Tables used departed from quinary grouping at ages under 35 , and although Case and Pearson (1955) were able to interpolate sufficiently accurately for environmental analysis below this age, the cohort analyses used in these studies are confined to the age range 30 to 84 except in the case of Leukaemia and Hodgkin's Disease, where the source Tables are consistently divided into quinary groups. Although the concordance enabled the classification to 21 sites defined in 1911 to be followed throughout the years, certain changes in the way of classifying the cause of death to which a death certificate was assigned were introduced in 1939. The information published by the Registrar-General (1944) in the "Statistical Review" for 1939 has allowed the calculation of a correction factor for many sites, indicated in Appendix Table I, but there remains a possibility of a discontinuity in rates around 1940. This will be most marked in the older age groups.

The rates have always been calculated from figures that include non-civilians, for there is a marked difference in the rates for civilians and non-civilians, doubtless due to selection of fit subjects and the discharge of cancer patients from the services.

A variation in one disease-specific age-specific death rate does not compel any other disease-specific agespecific rate to alter; indeed, such a concomitant change will take place only if there is a synergism or antagonism between the lethality of the two diseases. The mortality from All Causes is, as the name implies, the sum of all the disease-specific death rates for the relevant age and date.

The rates in the Tables form a domain for exploration and investigation of the mortality trends. The extent of this domain, and the main paths of exploration, are shown in Fig. 1.

Four main cohorts, formed by quinary-quinquennial grouping as described by Case (1956), are used consistently throughout the analysis. These cohorts were born around the central years 1871, 1881, 1891, and 1901; they are labelled with these dates and also with a distinctive symbol which is used to plot each value (Fig. 1).
DATE

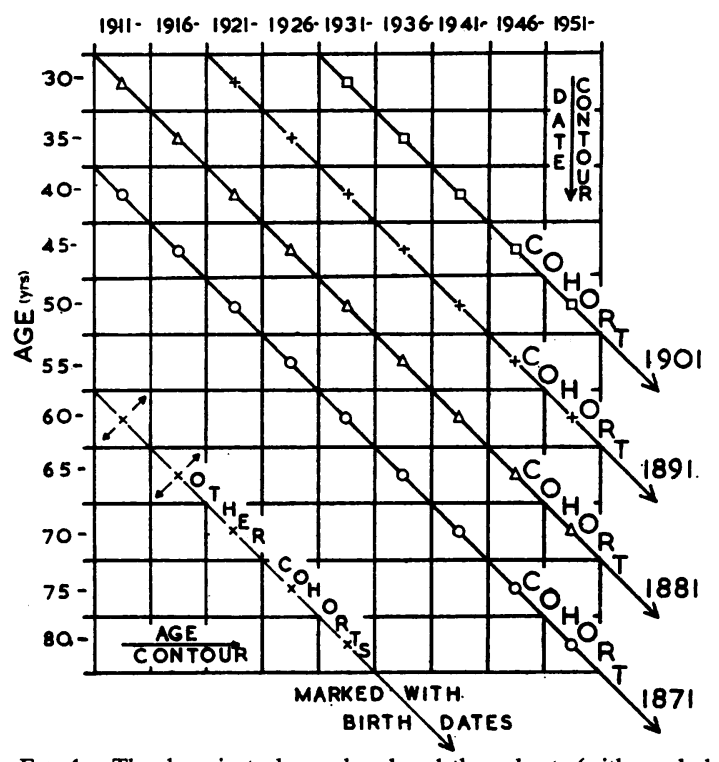

FIG. 1.-The domain to be explored and the cohorts (with symbols) used in the exploration.

These particular cohorts are chosen for the following reasons:

(1) The 1871 cohort attained the 80-84 age group in 1951-55, and thus became statistically extinct, passing into the indeterminate age group 85 and over for which no meaningful death rate can be computed.

(2) A period of 10 years between the cohorts is a convenient interval since it does not obscure the picture with-too much detail, as the consistent use of a 5-year interval would do.

(3) The age group 50-54 is about the lowest at which analysis of the trend is profitable, and this is the age group attained by the 1901 cohort in the last quinquennium of the domain.

Sometimes it is desirable to use another cohort to help to elucidate some feature of interest in a particular picture. When this is done the extra cohort, which uses a symbol common to all such extra cohorts, is marked with the date of the central year of birth.

All death rates are plotted as rates per 1,000 living per year, and no logarithmic transformation has been made lest this obscure the narrative property of the method for readers who are not familiar with such a transformation.

It is of course a commonplace that death certificates are not an accurate measure of either mortality or morbidity from particular causes. The errors involved have been discussed at length by Kennaway and Kennaway (1936) and by Willis (1953). They will apply to any method of analysing age-specific death rates, and are not a special complication of cohort analysis.

The use of morbidity data for England and Wales is impossible because such records are not available in 
sufficient detail, and even if the Cancer Registration Scheme described by the Registrar-General (1955) could now be considered perfect, 45 years would have to elapse before a morbidity analysis comparable with this mortality analysis could be made.

\section{RESULTS}

The results of these studies are set out in detail in Appendix Table I. They can fortunately be presented much more clearly in graphical than in textual form. The reader is therefore asked to study each figure in conjunction with the relevant text.

Fig. 2 (opposite) shows how the mortality rate from cancer at ages over 45 fits into the general mortality pattern of the four main cohorts. It also shows the proportion if the cancer mortality attributable to certain large groups of sites: Lung; Gut from cardia to anus, subdivided into Stomach, Intestines, and Rectum; Sexual Sites, subdivided into Uterus, Breast, and Others in the female, and into Prostate and Others in the male; and the aggregate of sites not included in these categories.

The picture for the 1871 cohort can be drawn up to the age of 85 , but the cohort 1881 had only reached the age of 70-74 in the final quinquennium of the domain, and so the picture must finish at that age. For each succeeding cohort the picture will finish progressively 10 years earlier. To make comparison easy, a strip from the preceding cohort or cohorts showing their pattern of mortality at the relevant age has been included in each picture.

In all the cohorts the male general mortality always exceeds the female general mortality, and the male cancer mortality exceeds the female cancer mortality at all ages above 55 . The general mortality is decreasing at all ages shown for females, and at all ages under 60 for males. The male 1891 cohort has an unfavourable mortality at age 60-64 compared with the 1881 cohort, though still favourable when compared with the 1871 cohort.

The cancer mortality for males increases in each successive cohort, whilst that for females decreases. The most dramatic feature of the cancer mortality broken down into the large subdivisions is the increase in mortality from cancer of the Lungs in males. In the 1871 cohort cancer of the Lungs was never a major item in the balance sheet. In the 1901 cohort at the age of 50-54, cancer of the Lungs accounts for about half of the total cancer mortality rate and for about one-eighth of the total mortality rate. In the female the rate for cancer of the Lungs though increasing, has not yet assumed major importance. The mortality rate from all forms of cancer other than cancer of the Lungs shows a progressive decrease in each succeeding cohort in both sexes, but the form of presentation using grouped sites does not throw much light on how this comes about.

The increase in the male mortality from cancer of the Lungs from the 1881 cohort to the 1891 cohort at the age of 60-64 is in itself sufficiently great to account for the increase in general mortality already discussed at that age. This is not to say that it is in fact solely responsible for this increase.

Part of the information gained from Fig. 2 is also presented in another form, which will be used consistently throughout the succeeding analyses. Fig. 3 (overleaf) shows the mortality rates for Cancer at All Sites for all the four cohorts drawn from the same origin on the age scale. Where such a plot results in lines running together, the cohort symbols are plotted on the horizontal level of the rate, though in some cases they are displaced laterally. The line joining the centre point of such symbols is broken into as many segments as there are lines run together. The advantage of this form of plotting is that it is simple to compare the mortality rate of a cohort at a particular age with that of the other cohorts when they were at that age.

Fig. 3 shows that the male cancer mortality rate for each successive cohort exceeds that of the preceding cohort, and that at age 50-54, the most advanced age where all four cohorts are depicted, the mortality rate of the 1901 cohort is 122 per cent. of that of the 1871 cohort at the same age. (Appendix Table II sets out this proportional change for each cohort at each site). The female cancer mortality rate has decreased in each successive cohort, and the mortality of the 1901 cohort at age $50-54$ is only 82 per cent. of that of the 1871 cohort at that age.

Fig. 4 (overleaf) shows the mortality rates for Cancer at All Sites except the Lungs. In both males and females there is now a progressive diminution in the rate for each successive cohort, the male rate for the 1901 cohort at age 50-54 being 68 per cent. of that for the 1871 cohort at that age, and the female rate 78 per cent.

The justification for analysing the cancer death rates with and without the contribution due to mortality ascribed to Cancer of the Lungs is that contemporary thought is sharply divided about the reason for the recorded increase of the mortality from lung cancer.

One school maintains that the increase is almost entirely spurious, being the. result of improved diagnosis. If this were true, since it would seem that the misdiagnosed cases would previously have been 

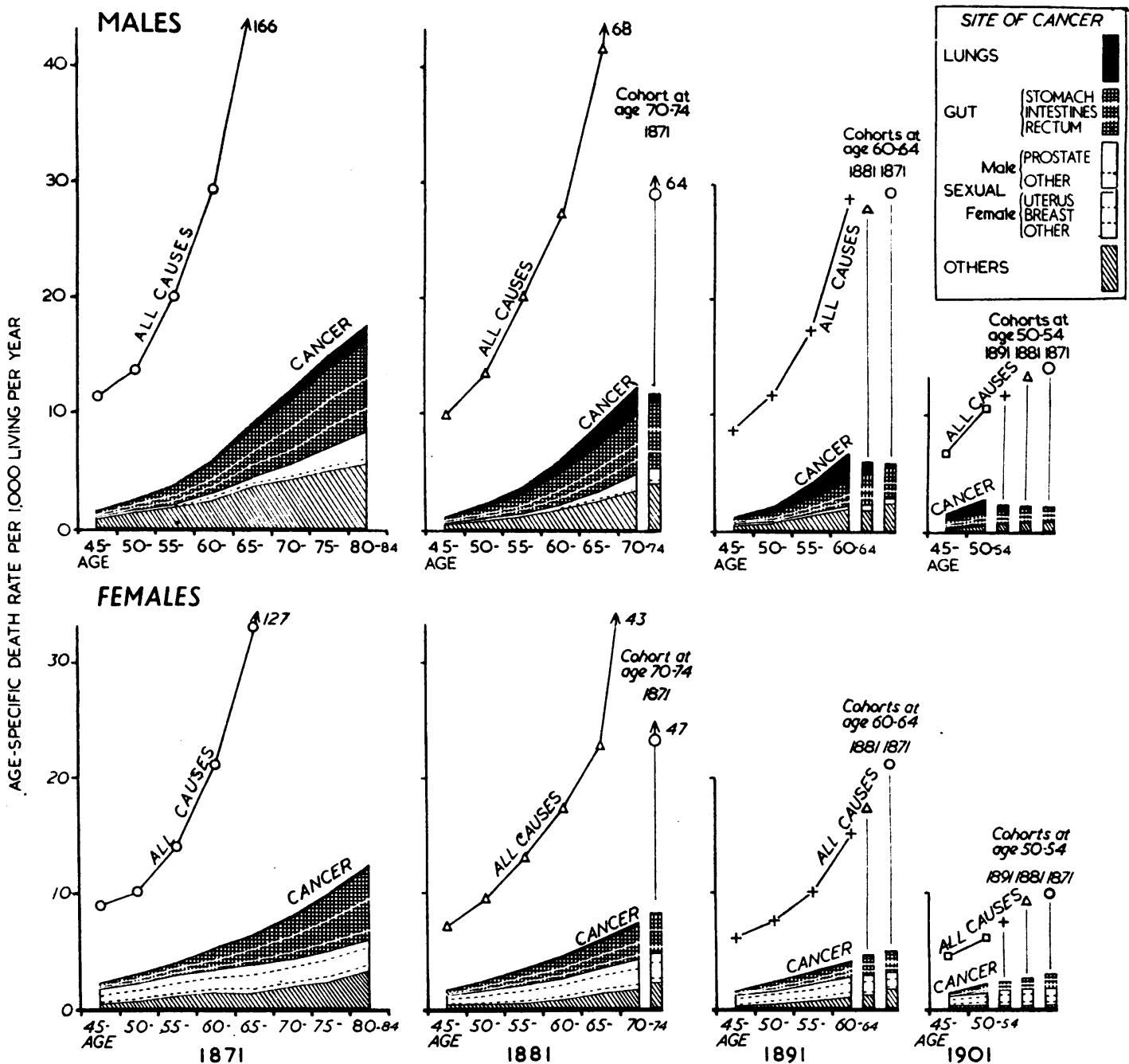

FIG. 2-The age-specific death rate picture for All Causes of Death (General Mortality) and for Cancer at

All Sites. The proportionate contributions of the main sites are also shown.

allocated to some disease category other than cancer, a progressively larger amount must be added to the cancer mortality rate of each cohort as the birth-date grows more remote. The final picture would then show a progressively diminishing cancer mortality, as in the female.

The other school, whilst not denying that diagnostic changes have taken place, asserts that a considerable part of the increase is due to environmental influences under human control. If this view is correct, the remedy lies in removing these influences. The interest in cancer mortality then becomes transferred to the residual sites of cancer, where as yet we cannot make any confident assertion about the causation of any large fraction of the mortality experience.

Figs 5 to 28 show cancer mortality at 21 different sites for each sex, three sites being sexually unique (Ovaries and Fallopian Tubes, Uterus, and Vulva and Vagina in the female; Testes, Prostate, and Penis and Scrotum in the male). Some of the site designations may well be considered quaint by present-day standards (e.g. Kidneys and Adrenals), but it was necessary to use the 1911 site classification; for, although it was possible to combine the more detailed groups that later made their appearance to give the original groupings, there was no way of subdividing the earlier omnibus headings. 


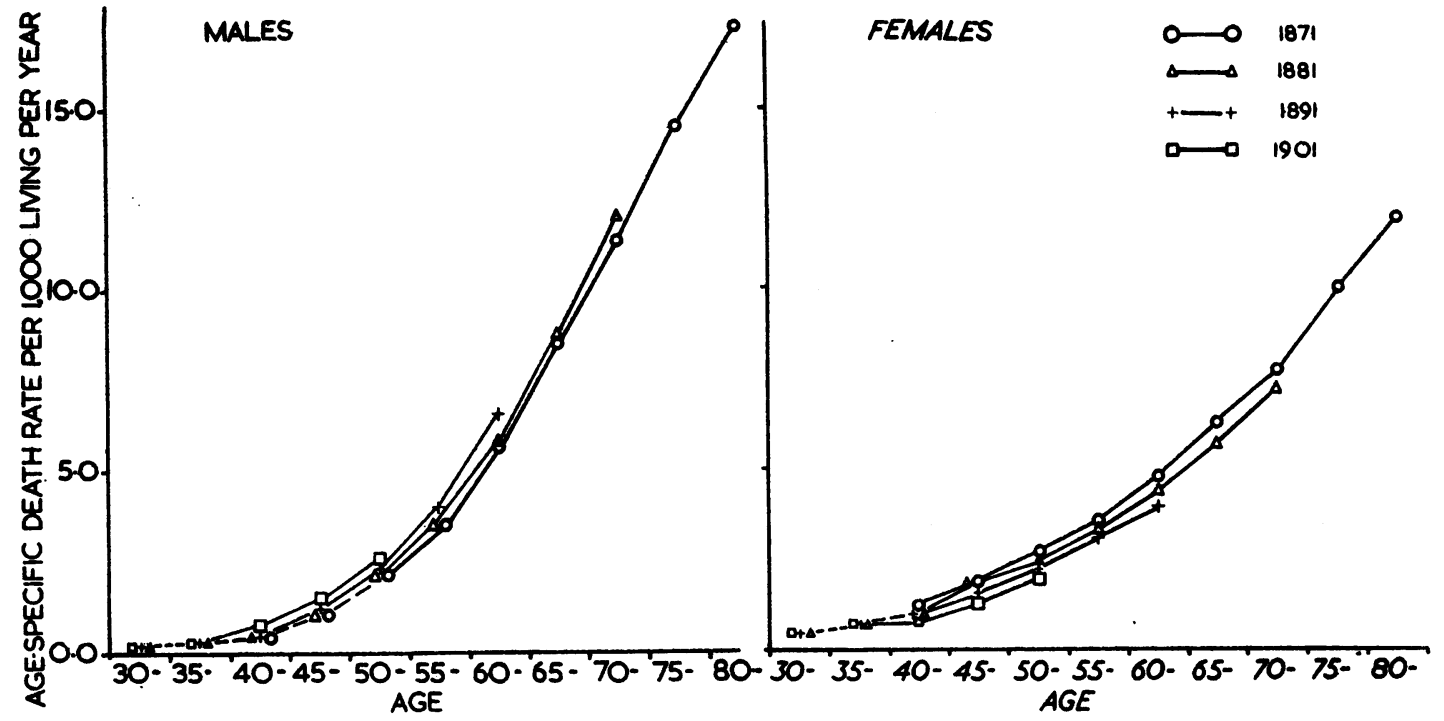

Fig. 3.-Cancer at All Sites.

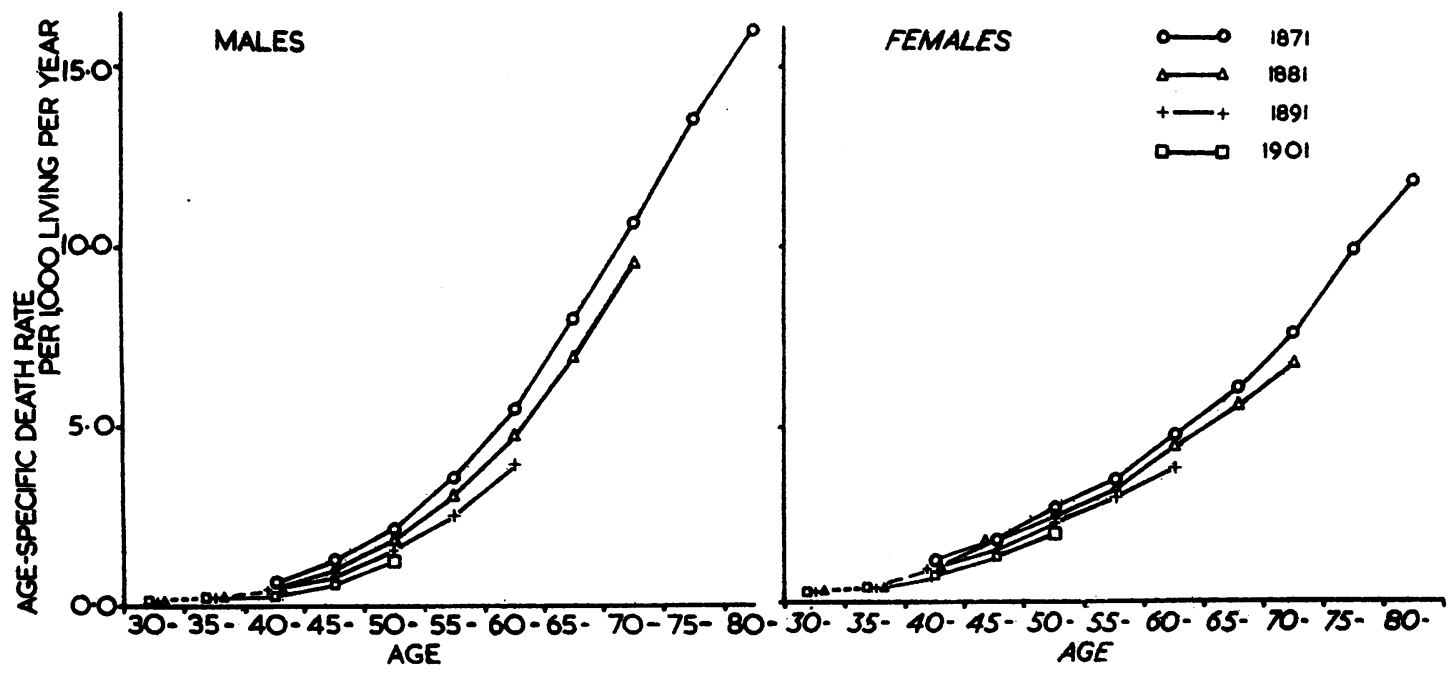

Fig. 4.-Cancer at All Sites except Lungs. 


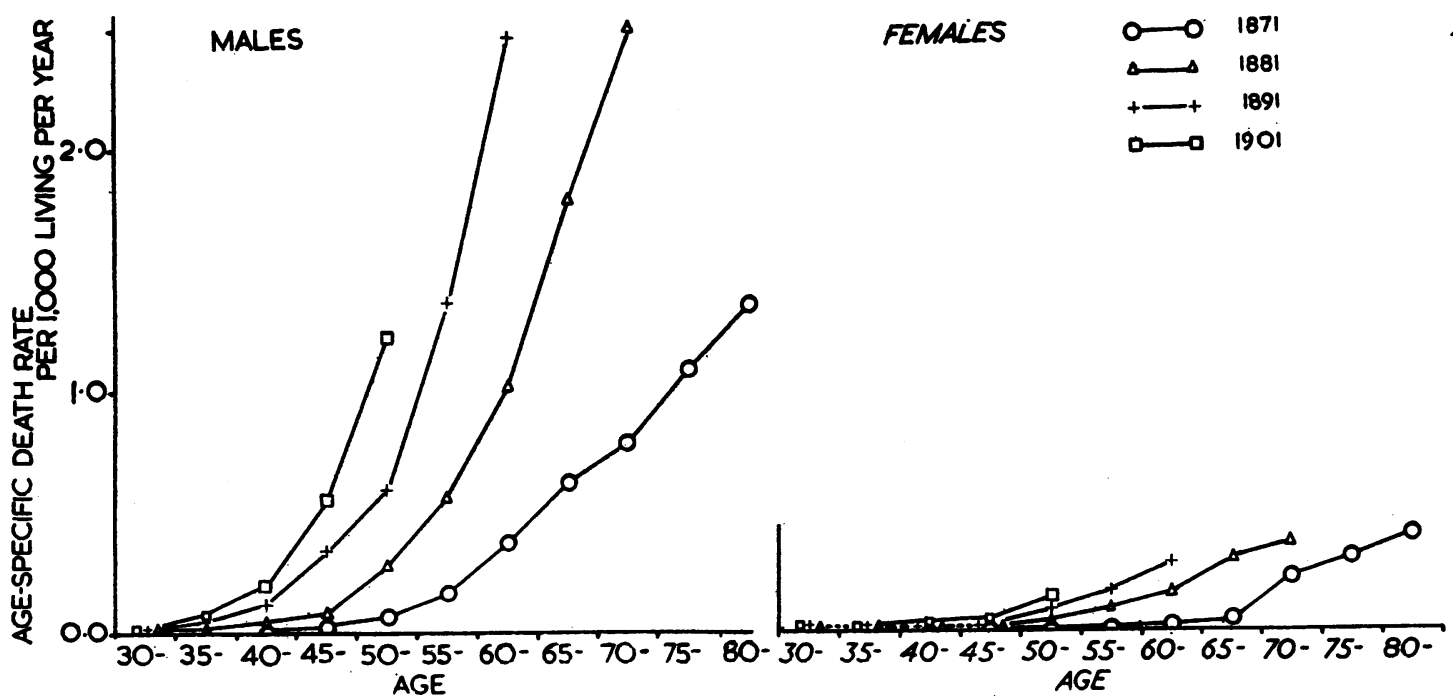

Fig. 5.-Cancer of Lungs.

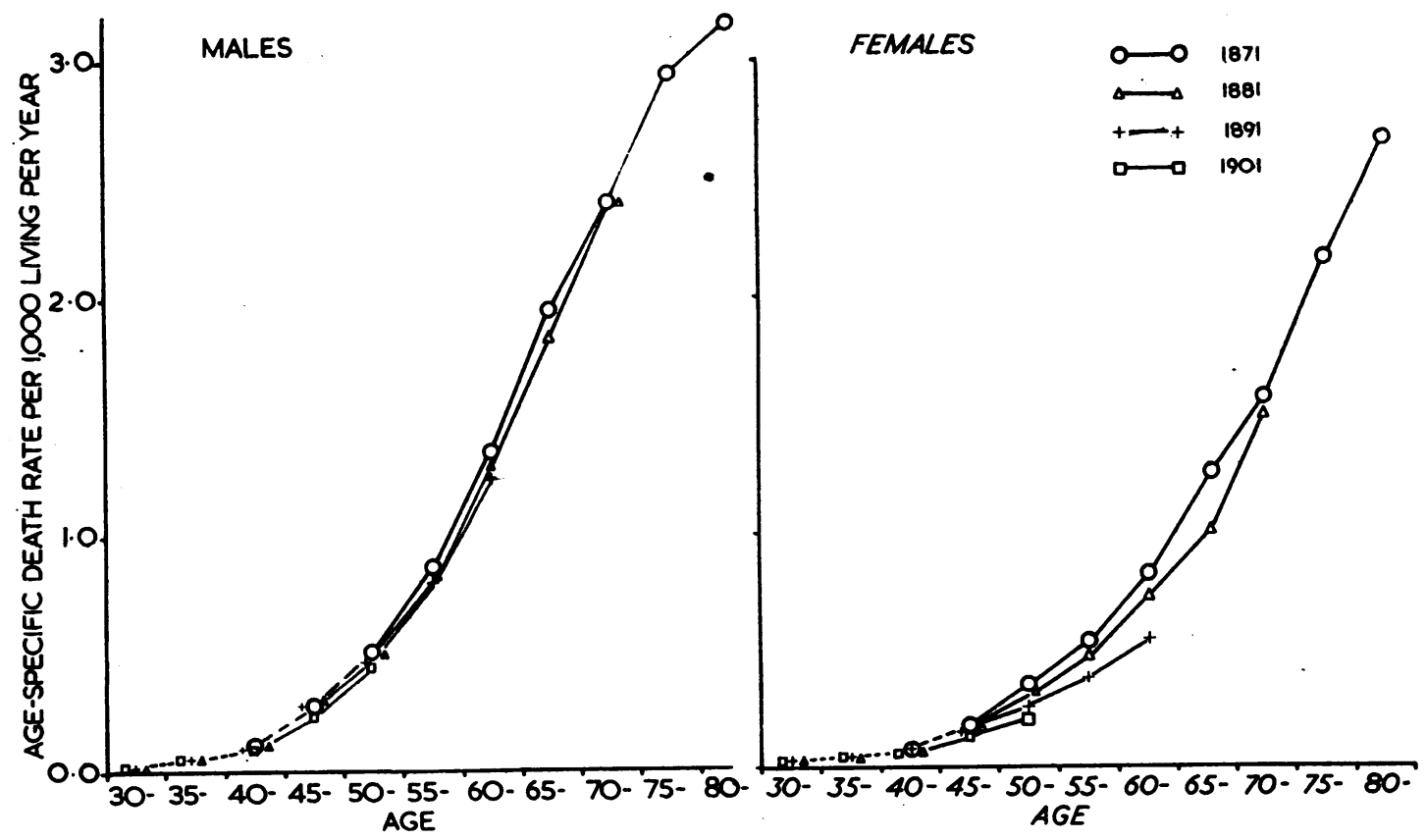

FIG. 6.-Cancer of Stomach. 


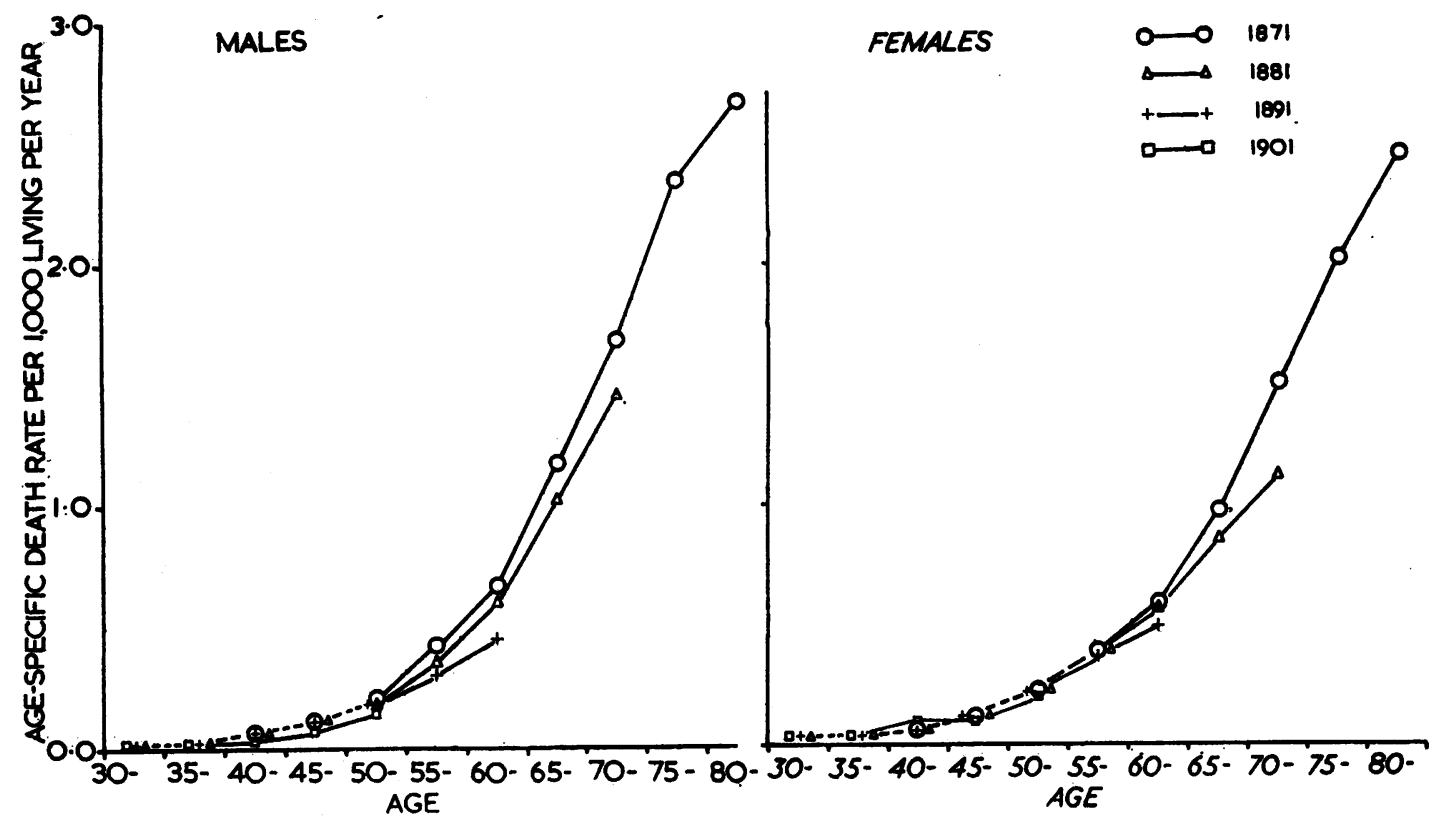

FIG. 7.-Cancer of Intestines.

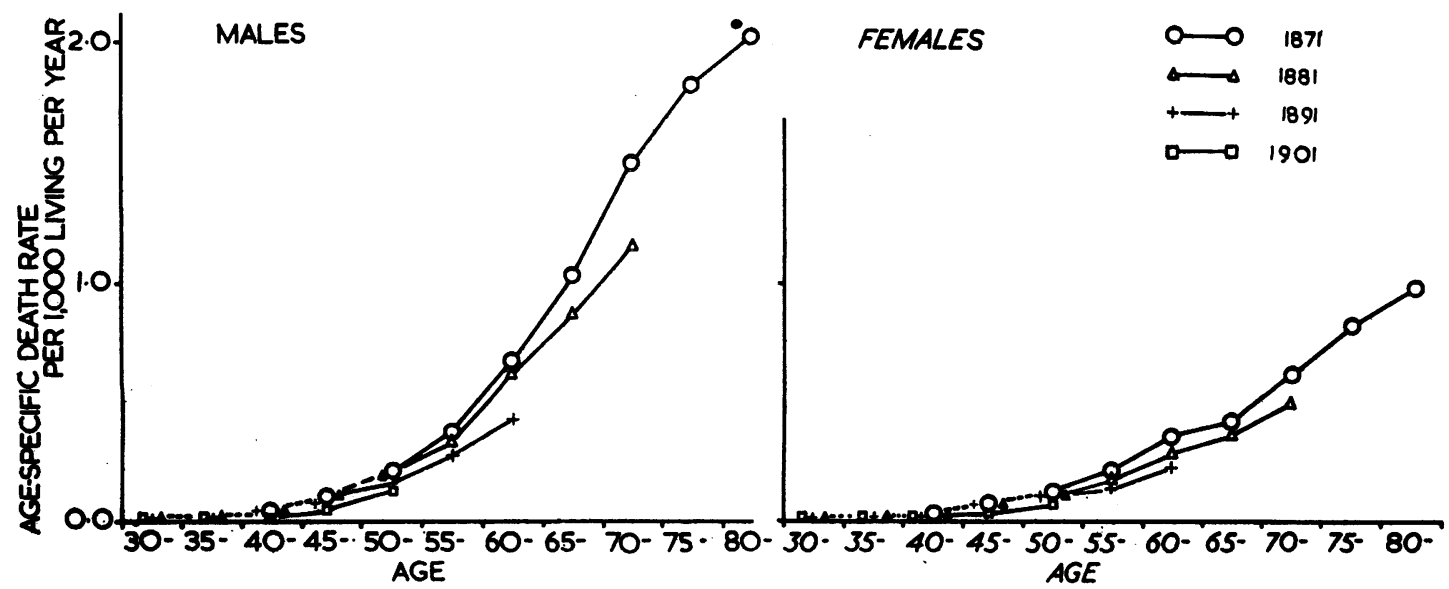

Fig. 8.-Cancer of Rectum. 


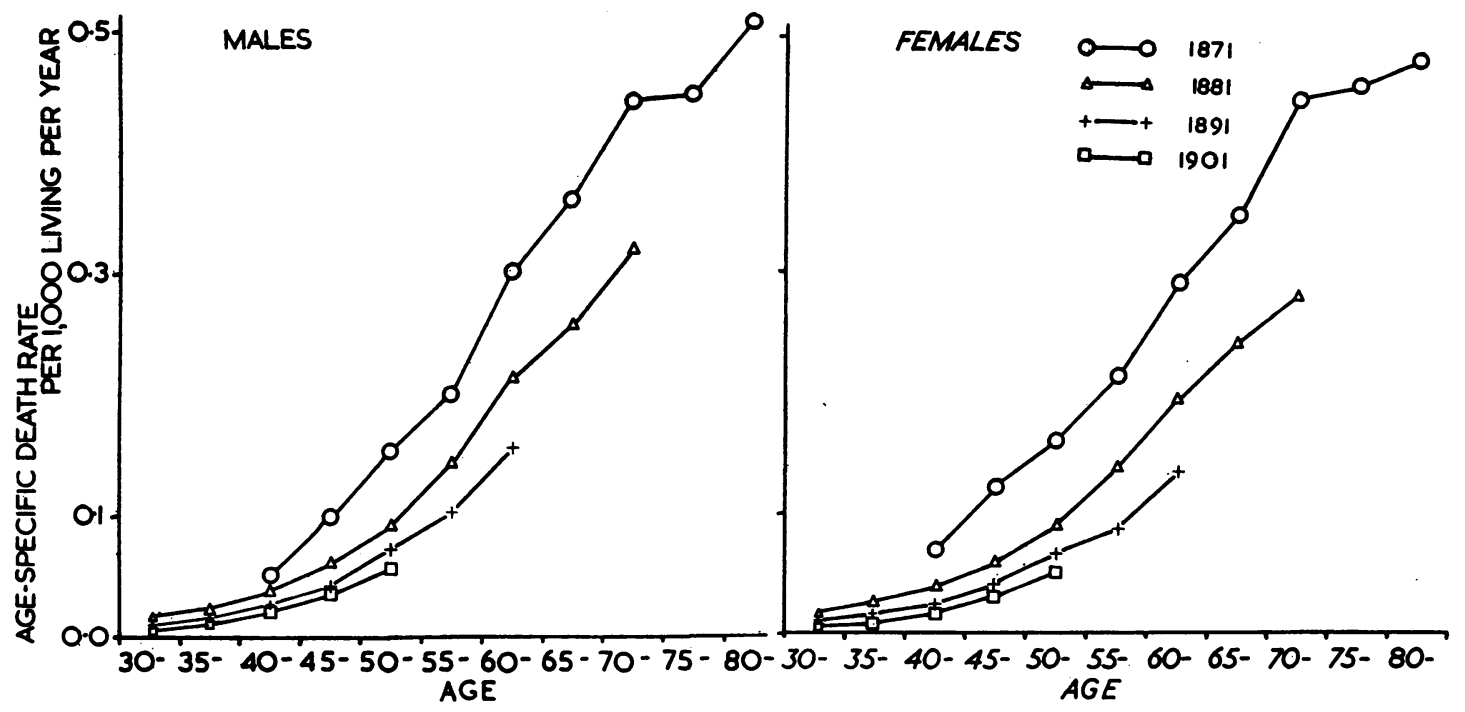

FIG. 9.-Cancer of Liver and Gall Bladder.

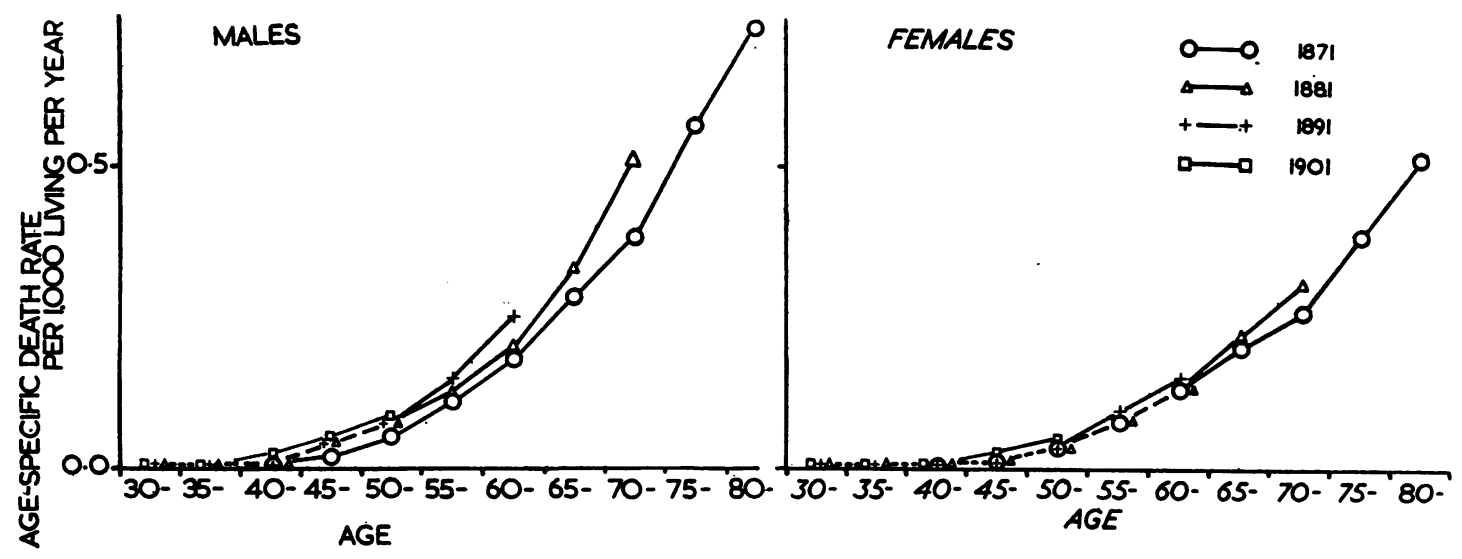

FIG. 10.-Cancer of Pancreas. 


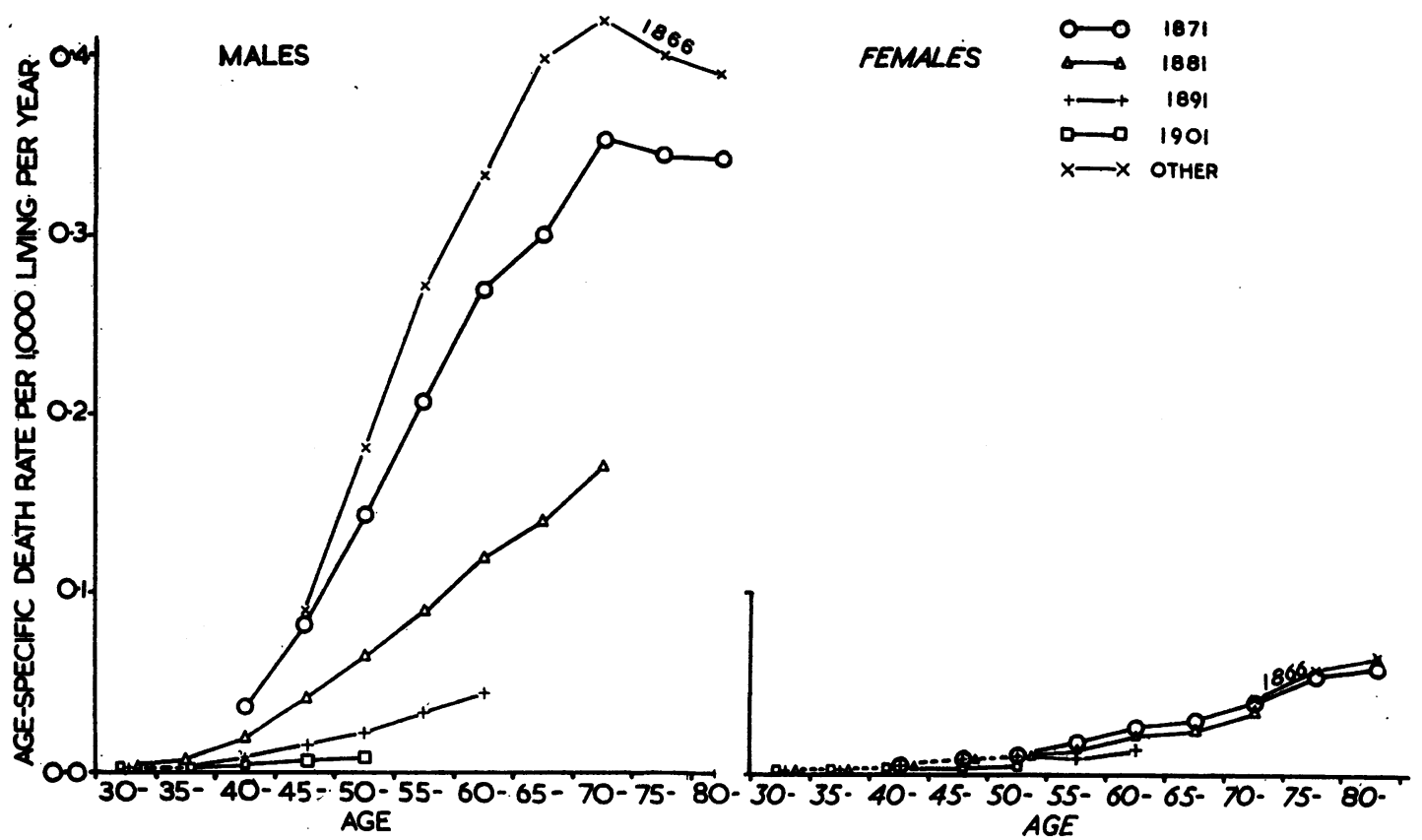

Fig. 11.-Cancer of Tongue.

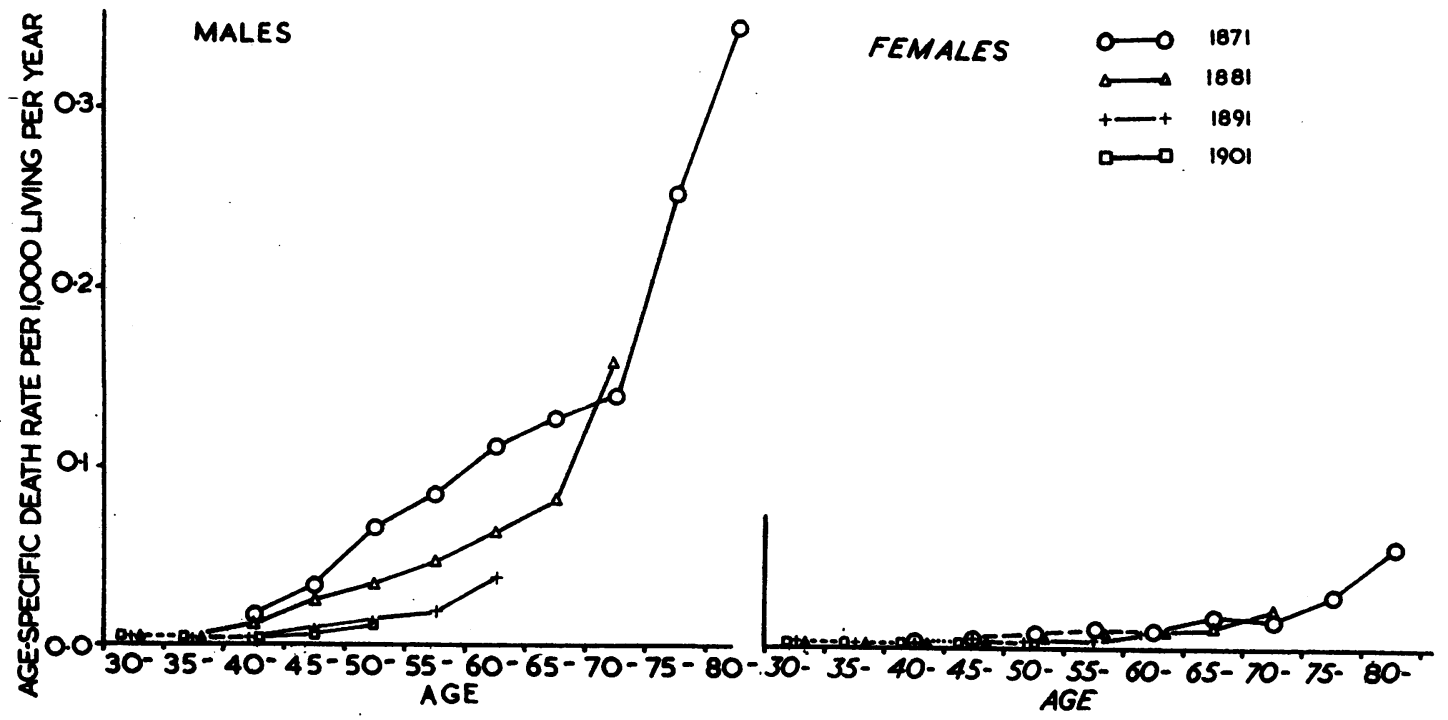

FIG. 12.-Cancer of Mouth and Tonsils. 


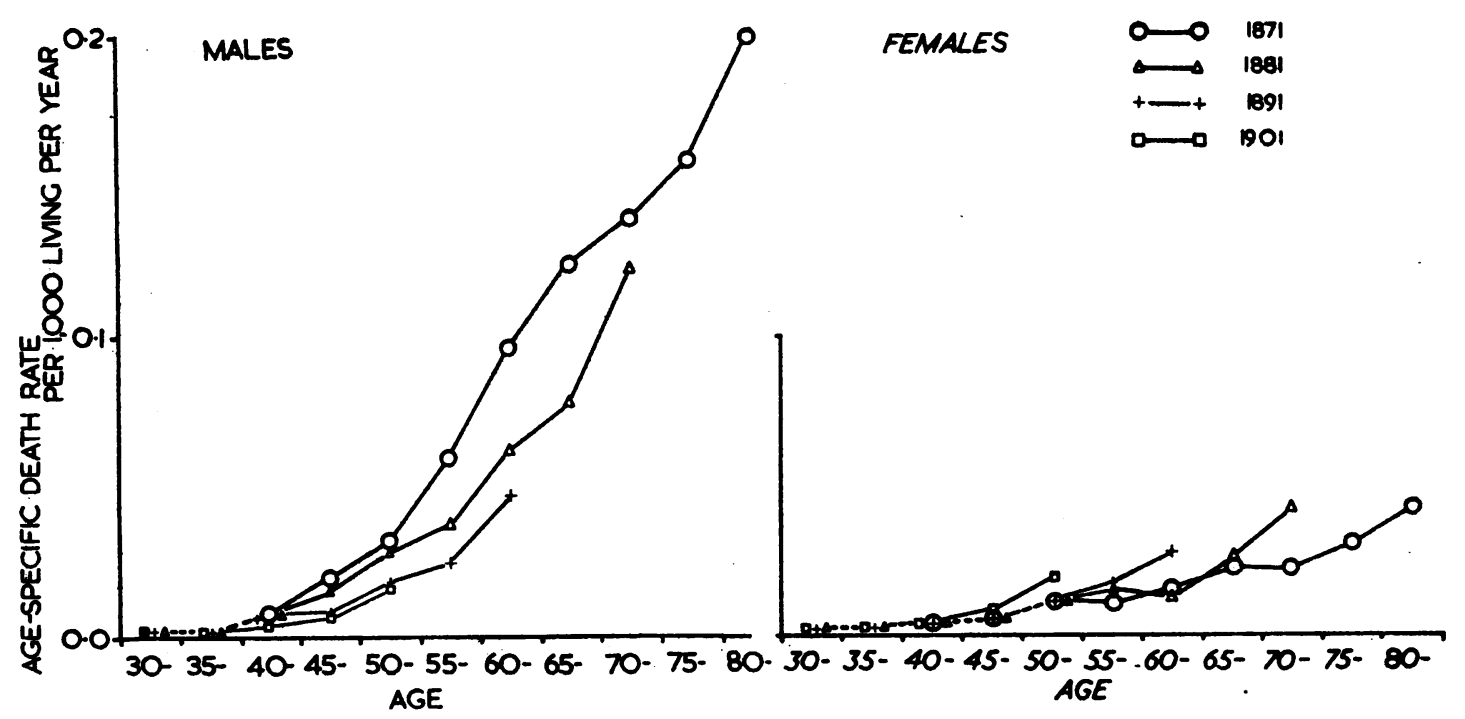

Fig. 13.-Cancer of Pharynx.

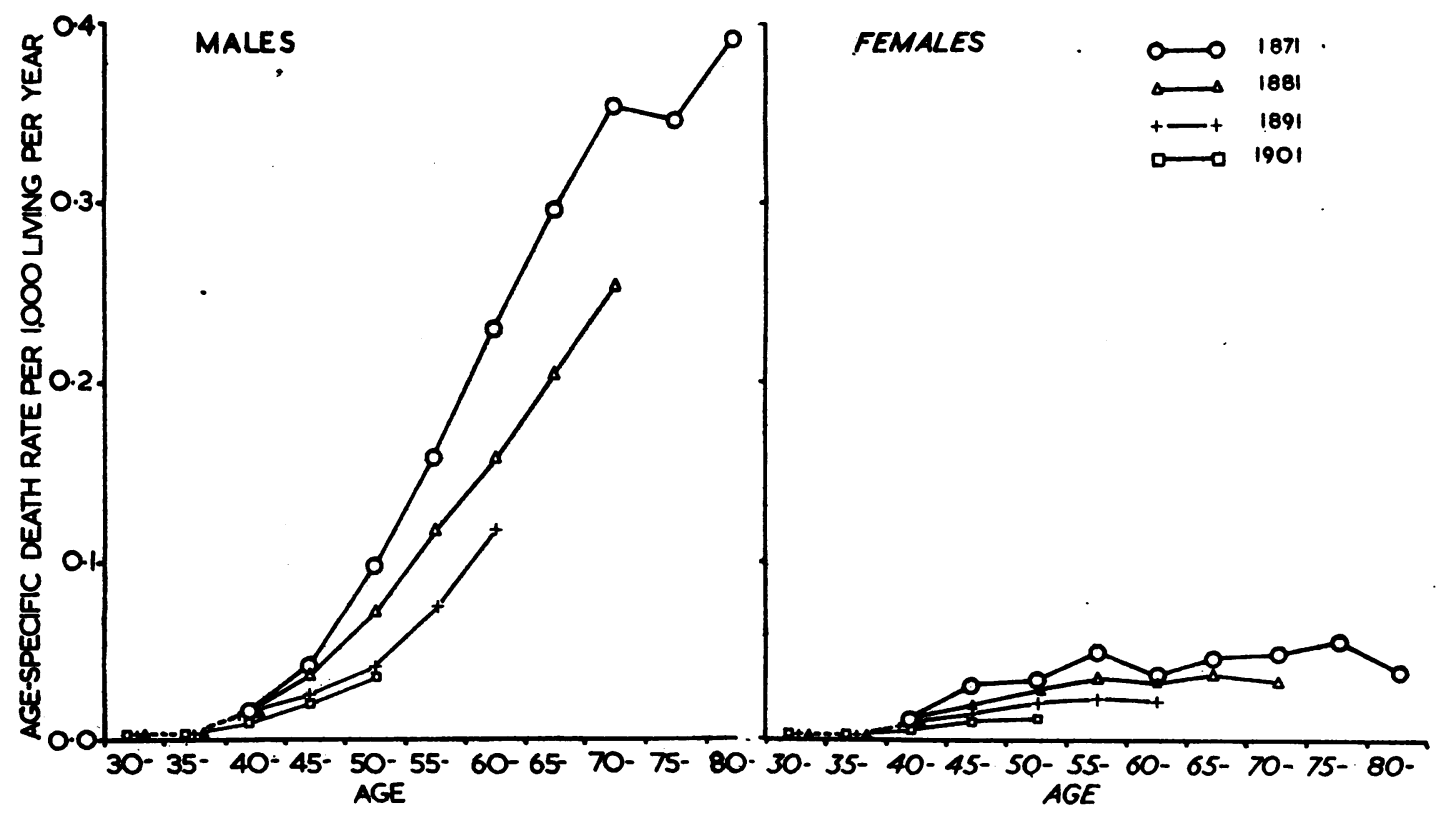

Fig. 14.-Cancer of Larynx. 


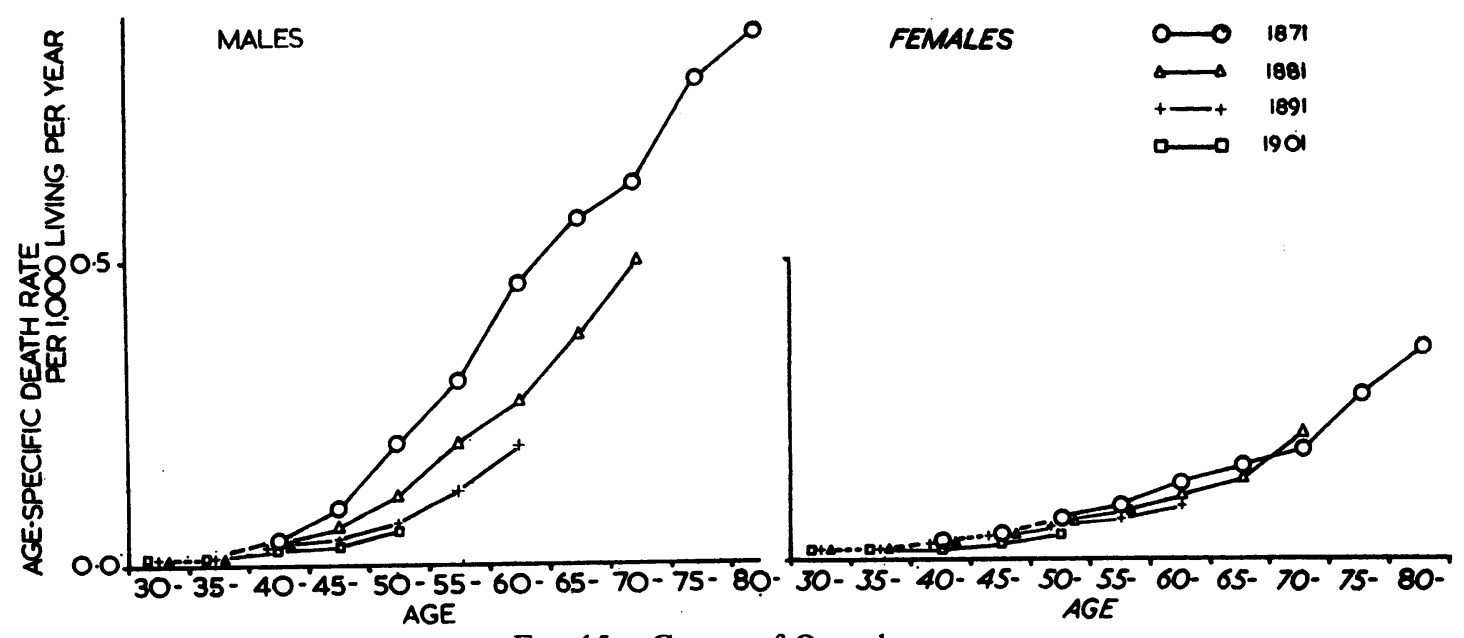

Fig. 15.-Cancer of Oesophagus.

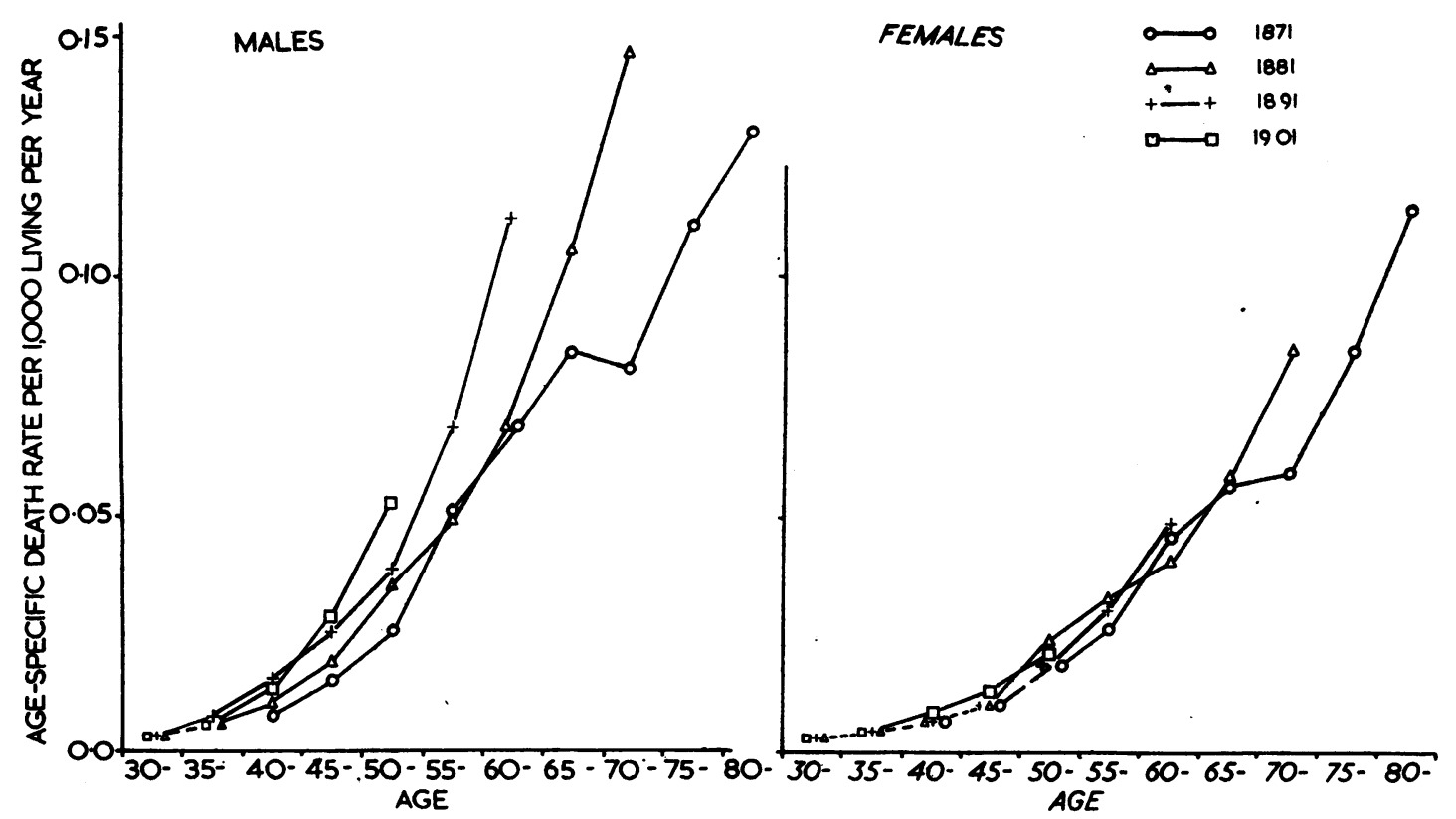

Fig. 16.-Cancer of Kidneys and Adrenals. 


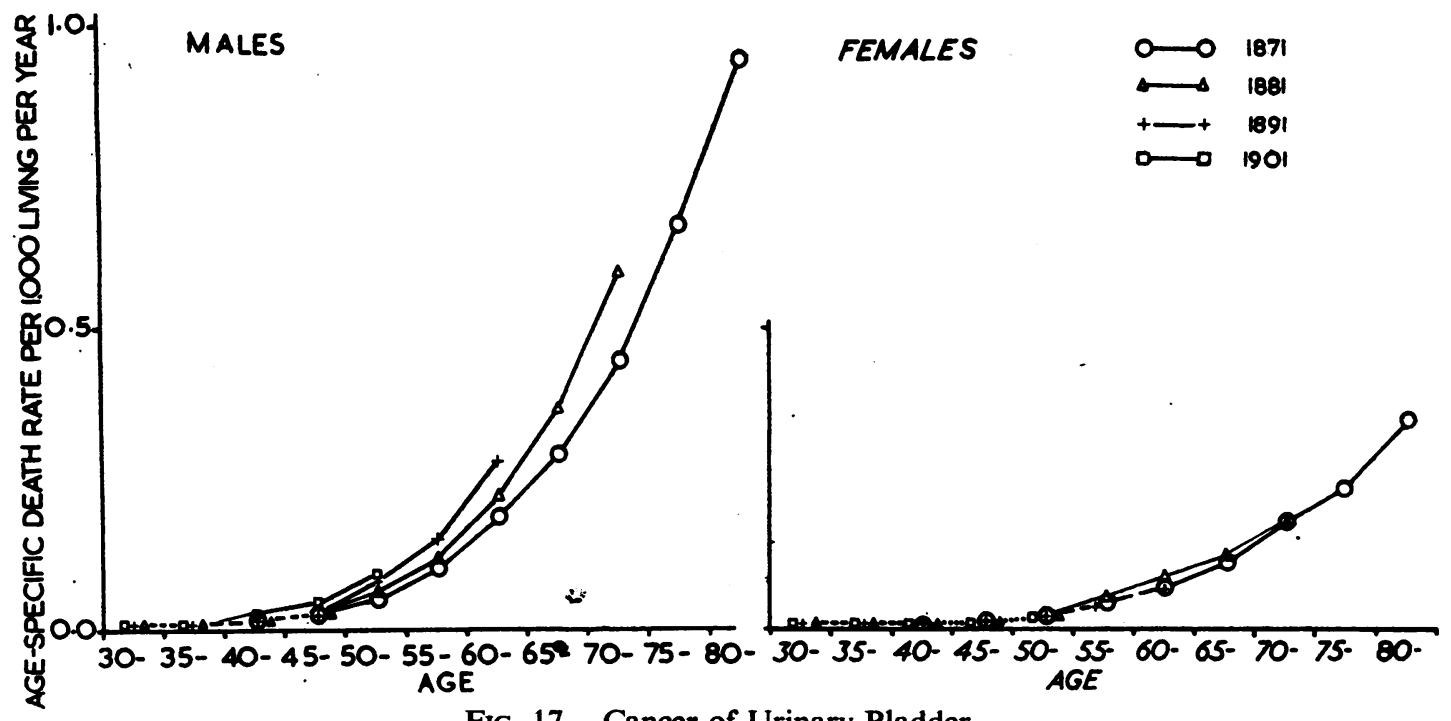

Fig. 17.-Cancer of Urinary Bladder.

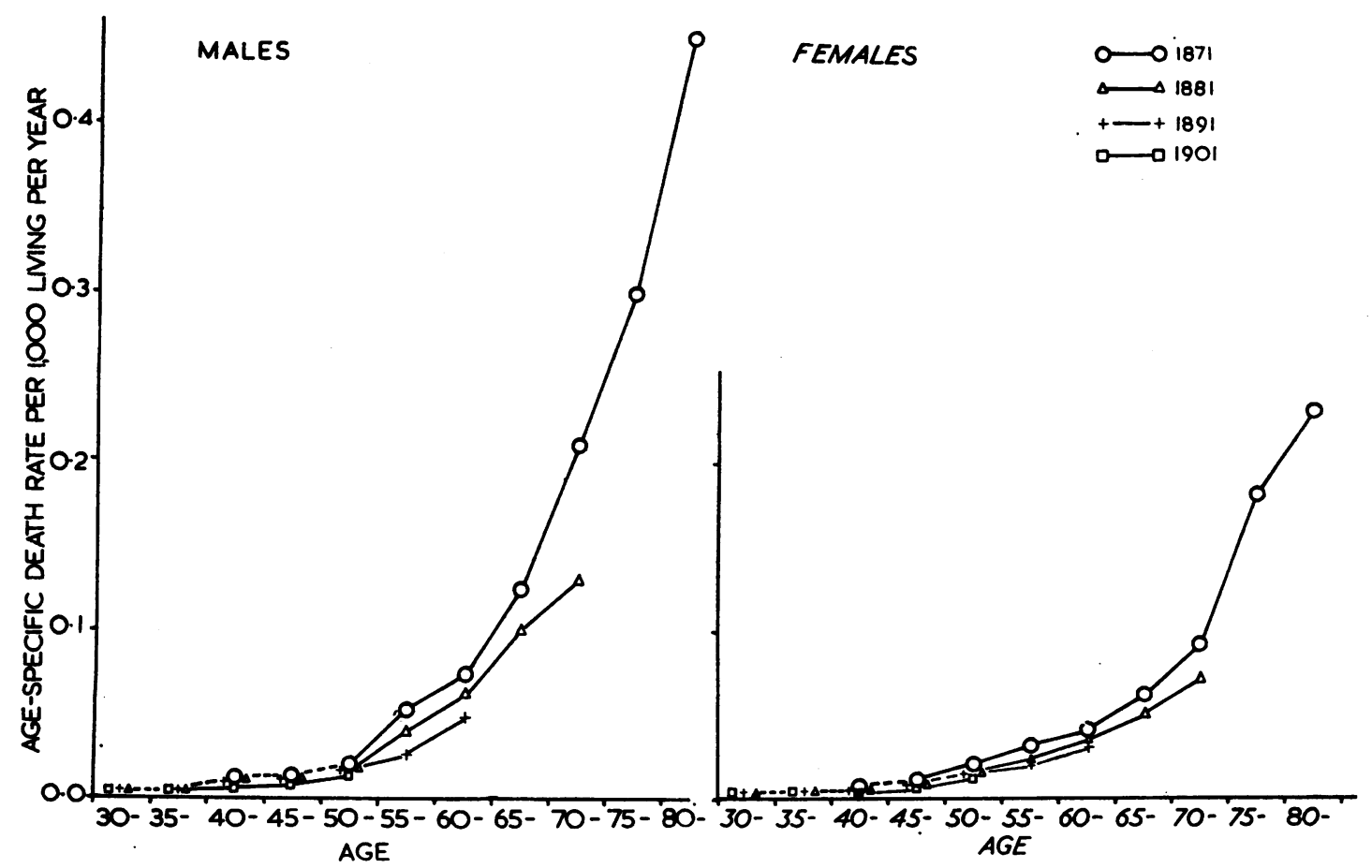

Fig. 18.-Cancer of Skin excluding Scrotum. 


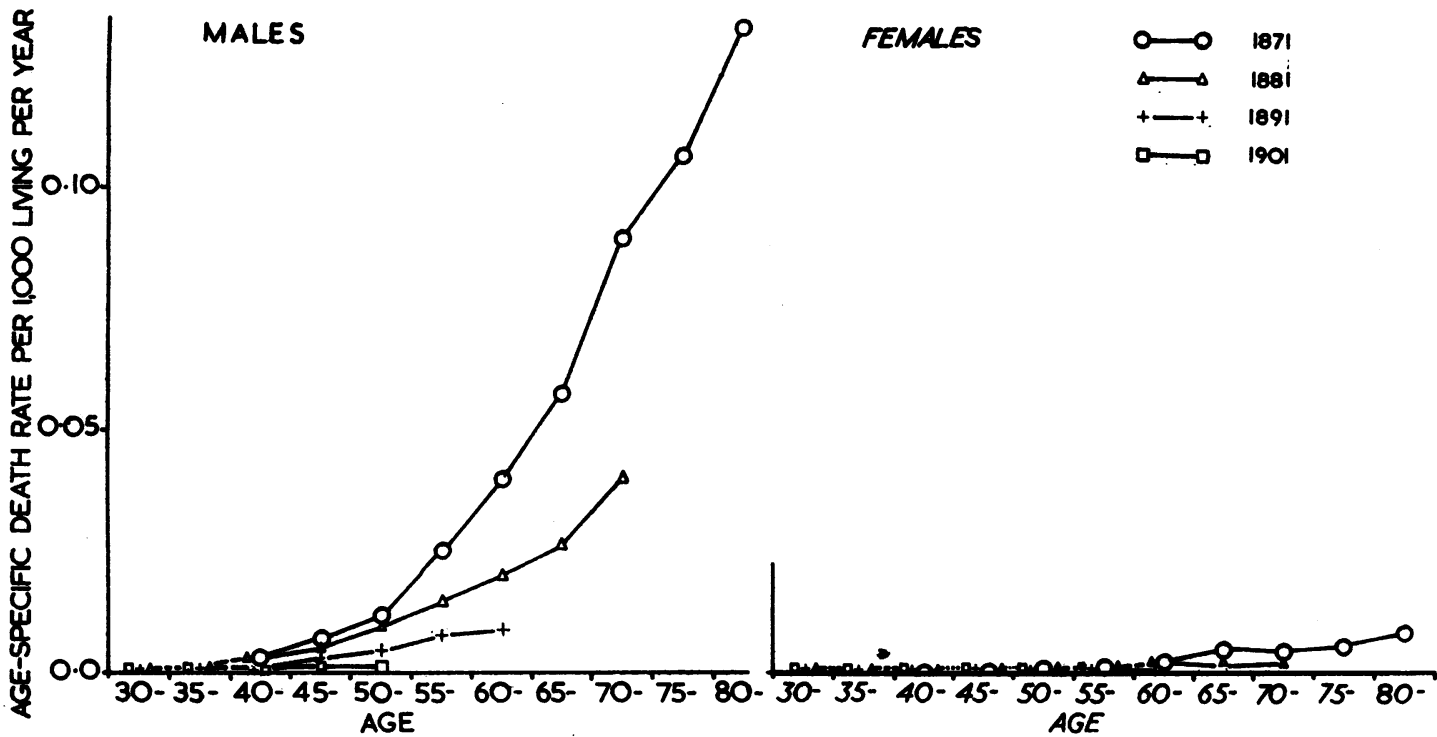

FIG. 19.-Cancer of Lips.

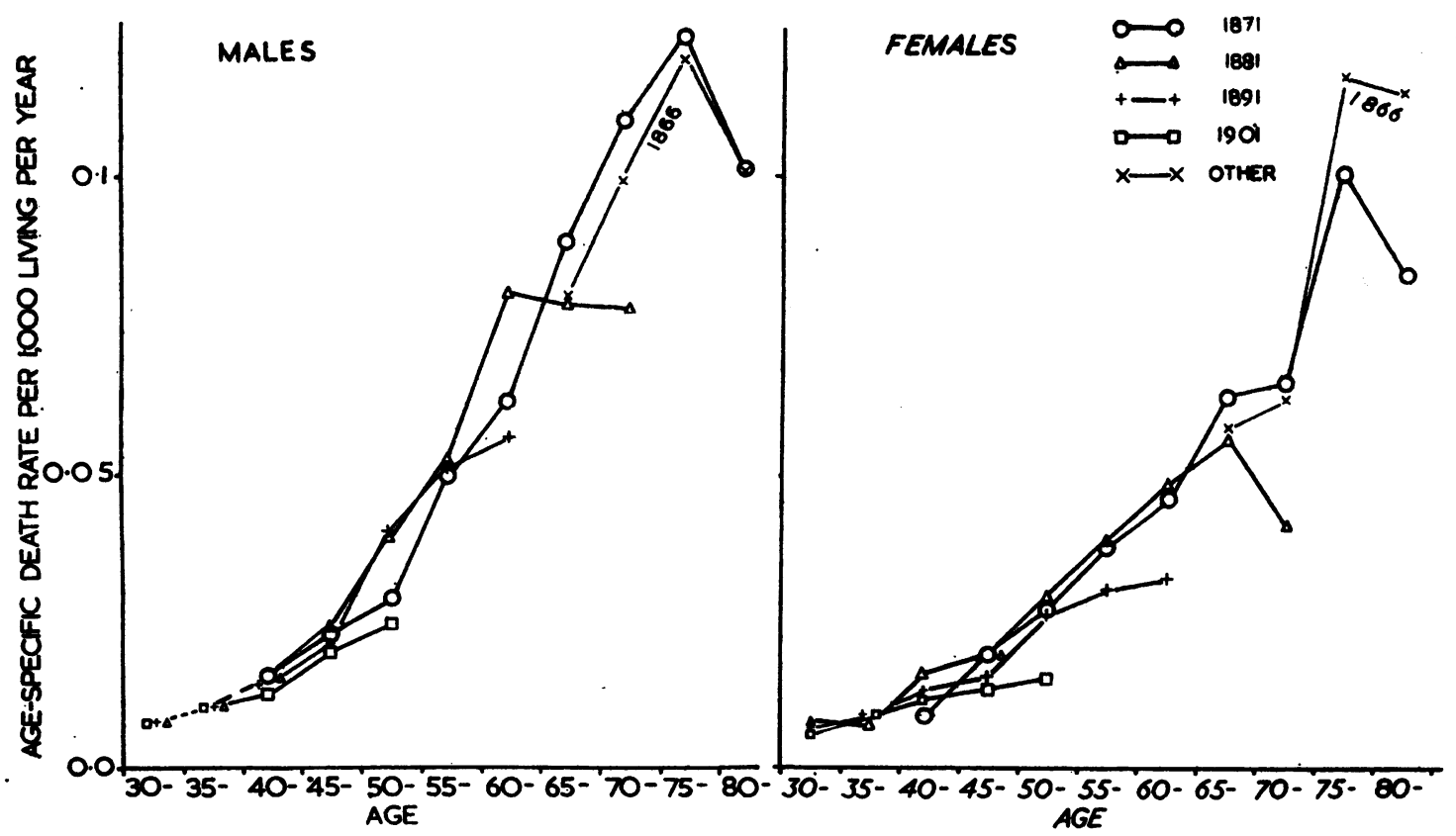

Fig. 20.-Cancer of Bones excluding Jaw. 


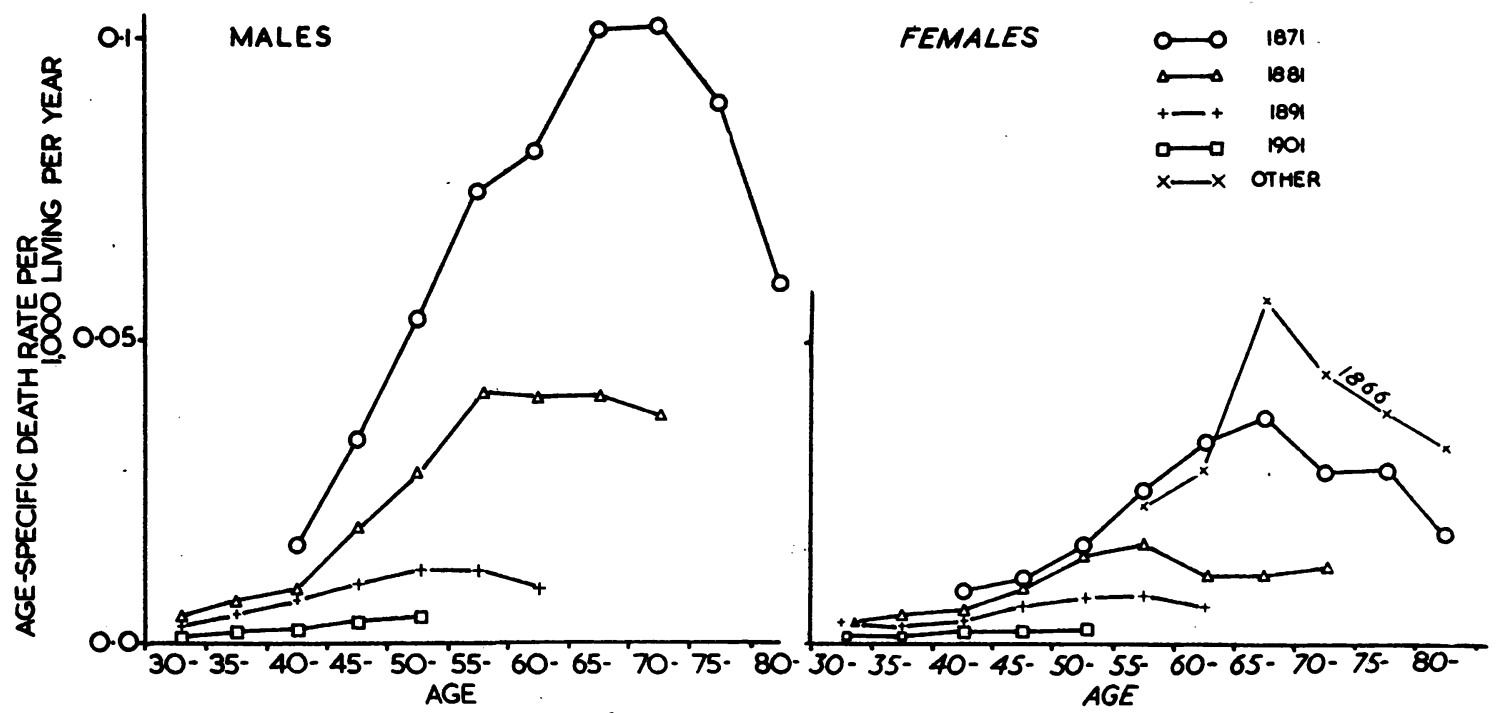

Fig. 21.-Cancer of Jaw.
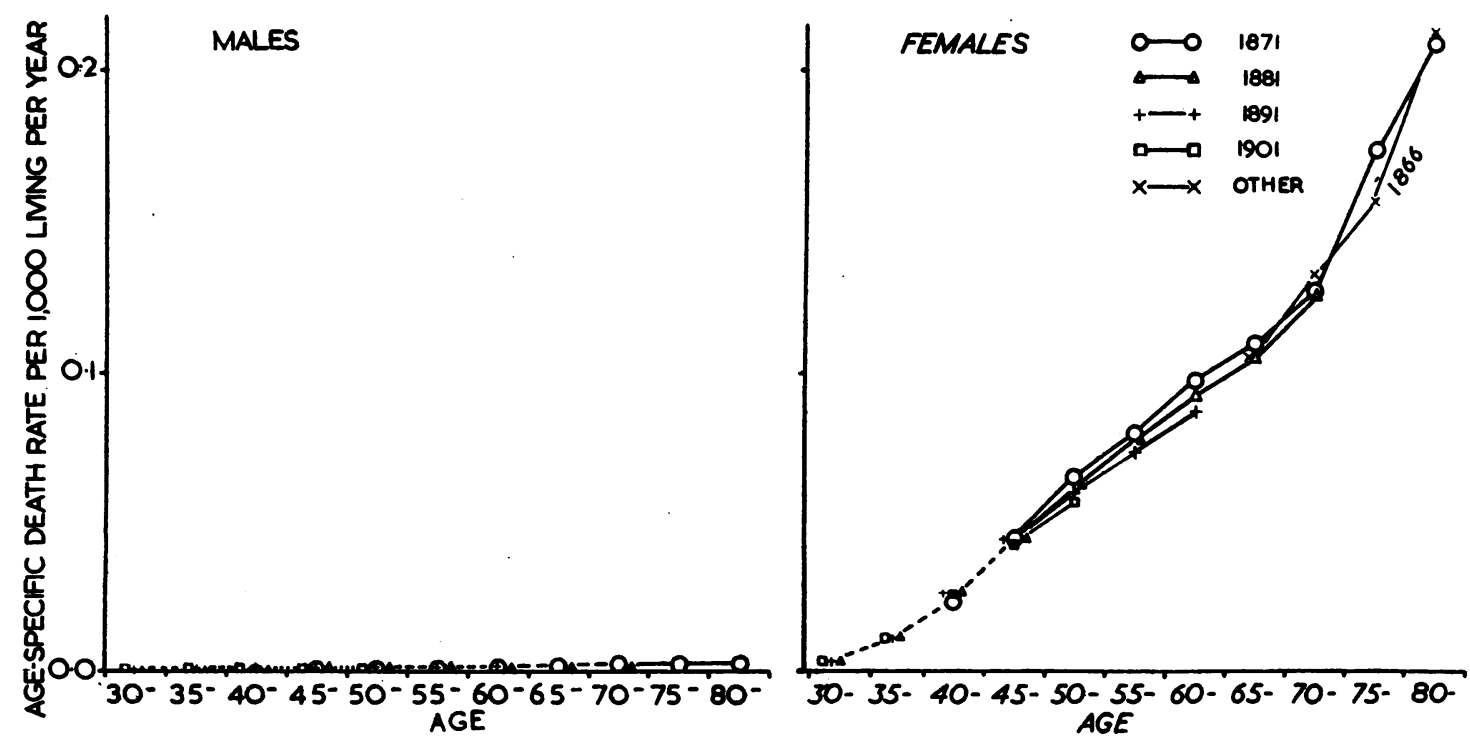

Fig. 22.-Cancer of Breast. 


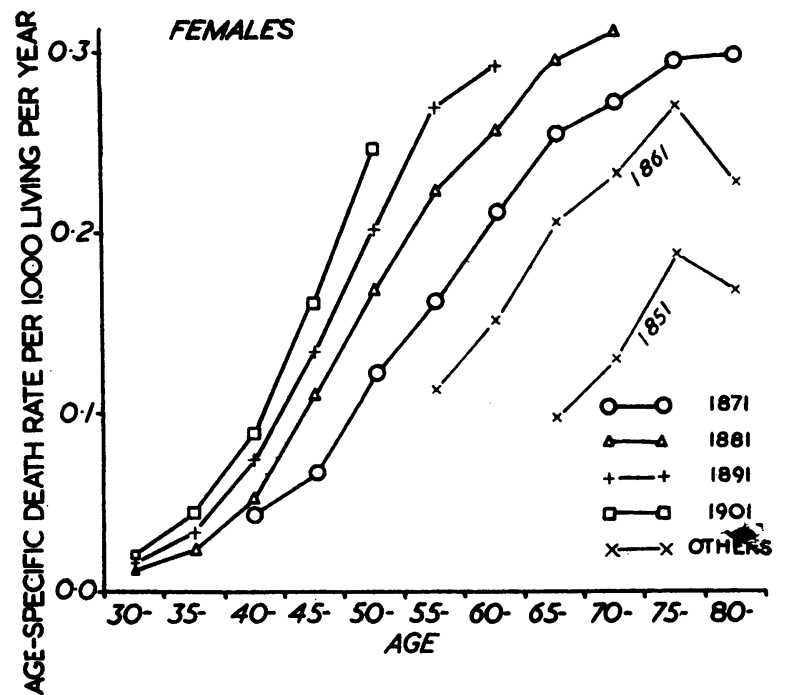

FIG. 23.-Cancer of Ovaries and Fallopian Tubes.

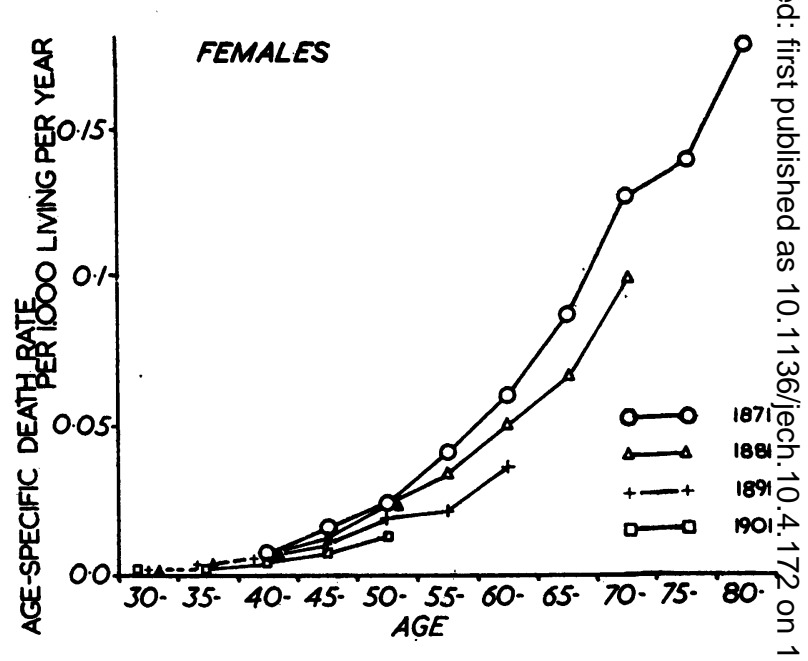

Fig. 24.-Cancer of Vulva and Vagina.

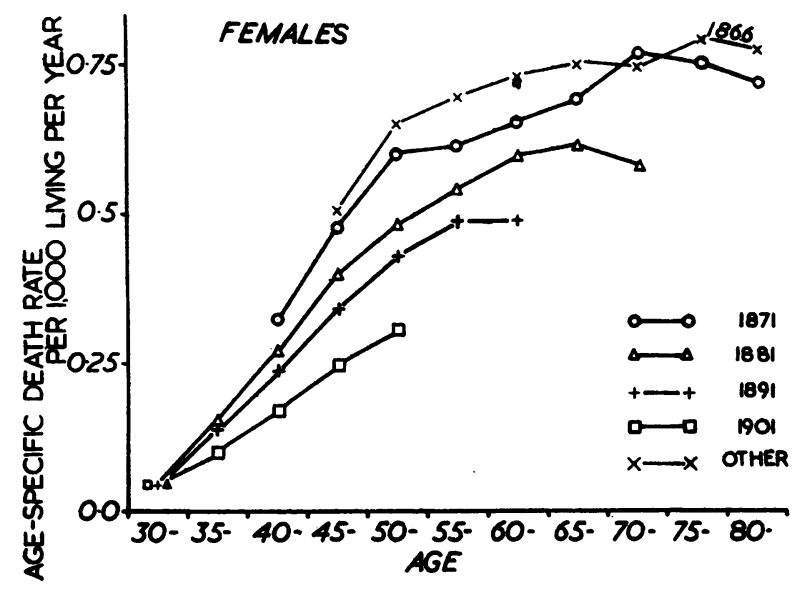

Fig. 25.-Cancer of Uterus. 


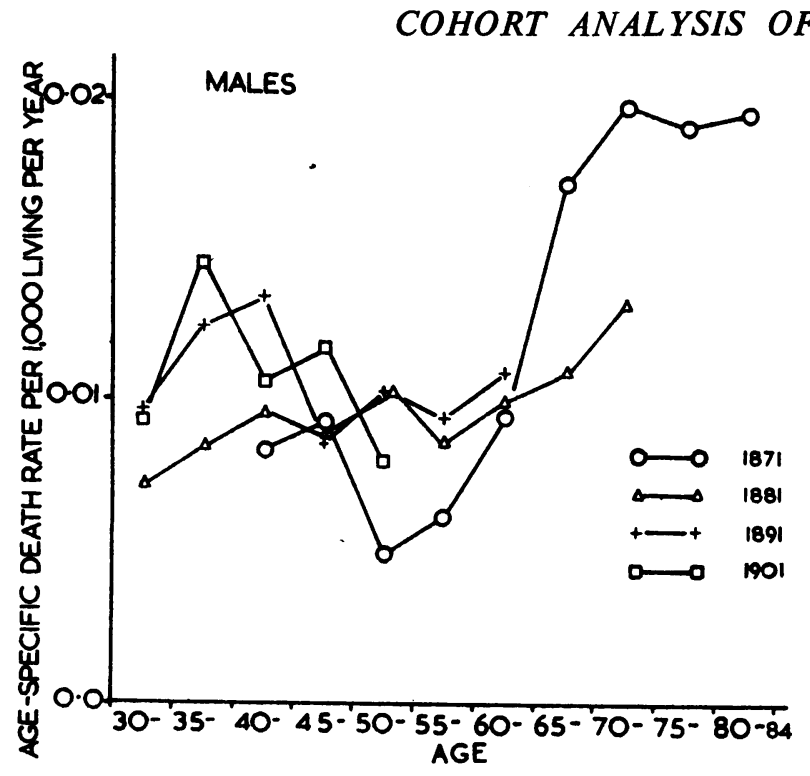

Fig. 26.-Cancer of Testes.

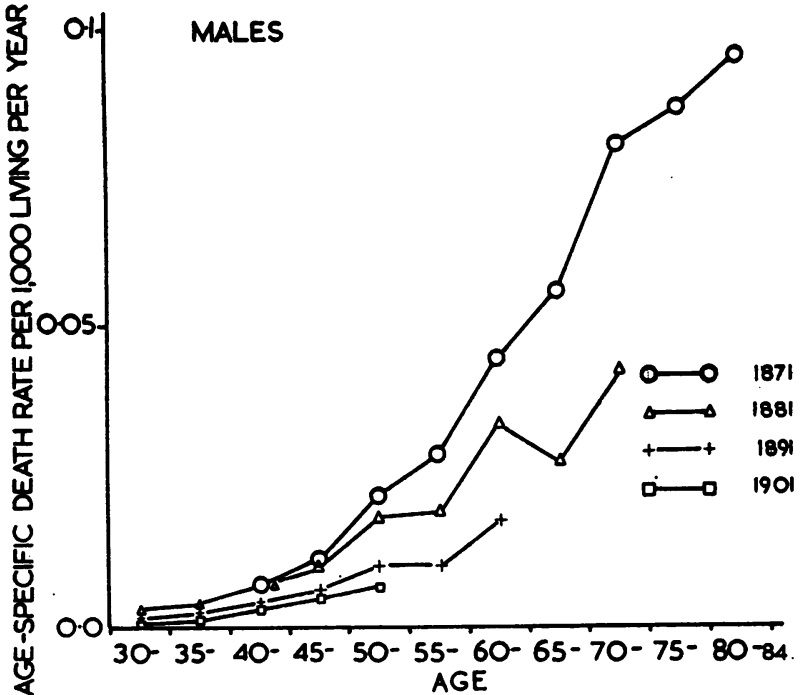

Fig. 27.-Cancer of Penis and Scrotum.

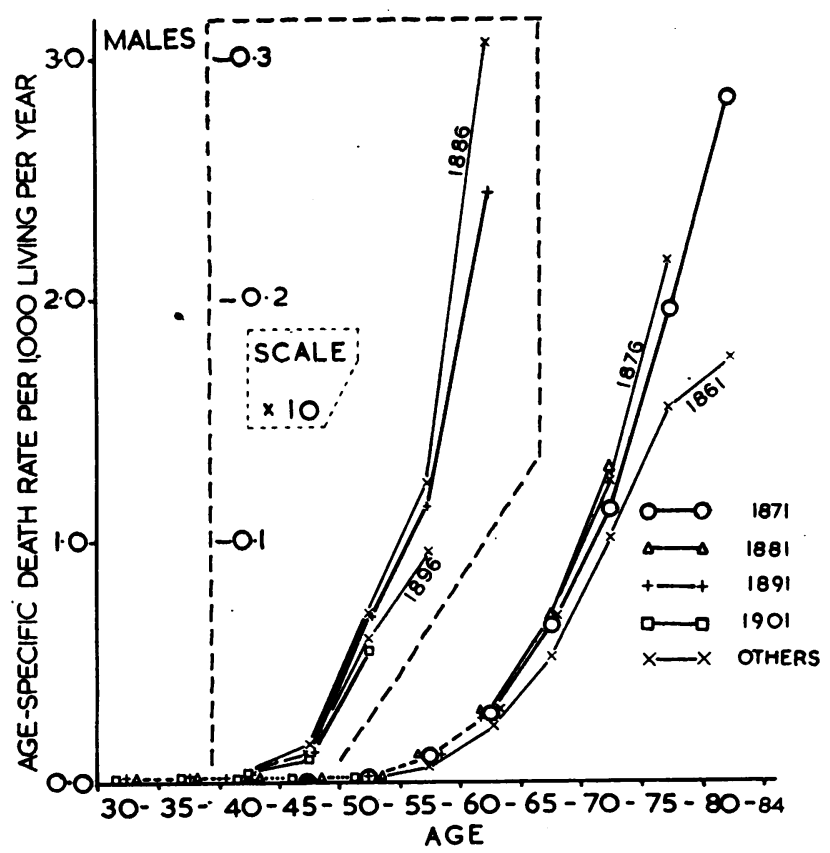

Fig. 28.-Cancer of Prostate.

(Inset: Tail of curve magnified ten times.) 
Fig. 29 shows the aggregate of the sites not included amongst the 21 sites enumerated in the Tables.

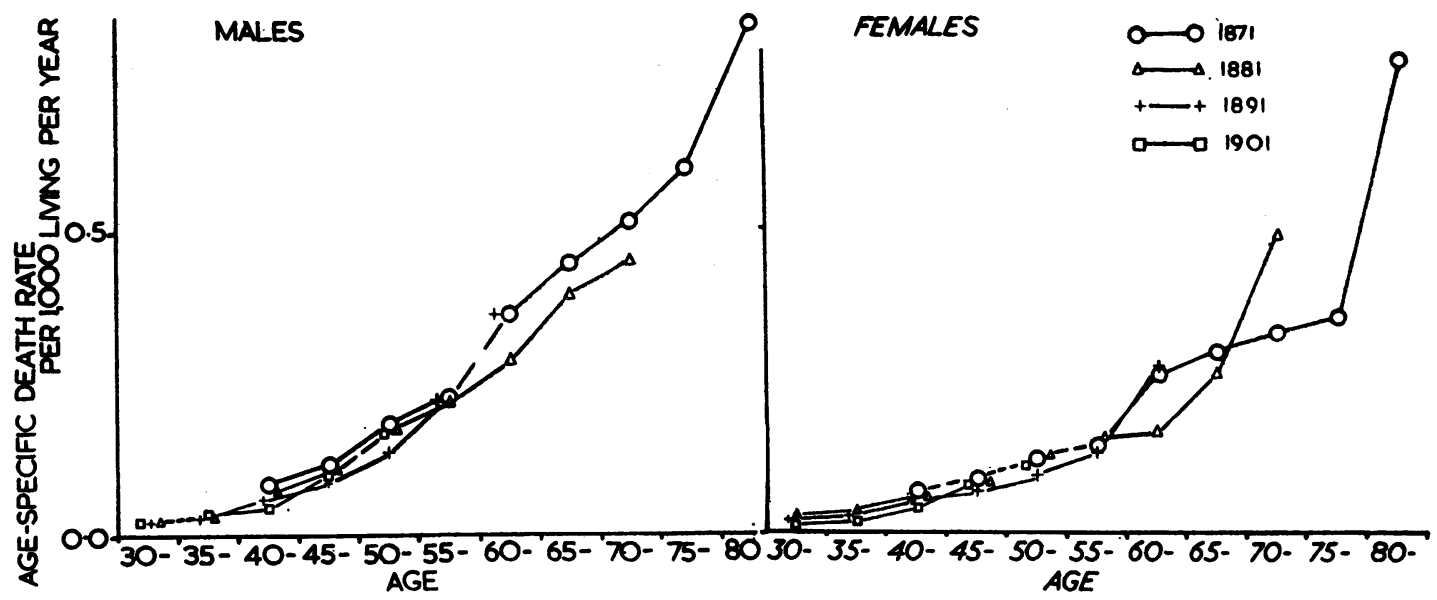

Fig. 29.-Cancer at All Other Sites.

Fig. 30, Benign Tumours and Tumours of Undetermined Nature, is put in for the sake of completeness.

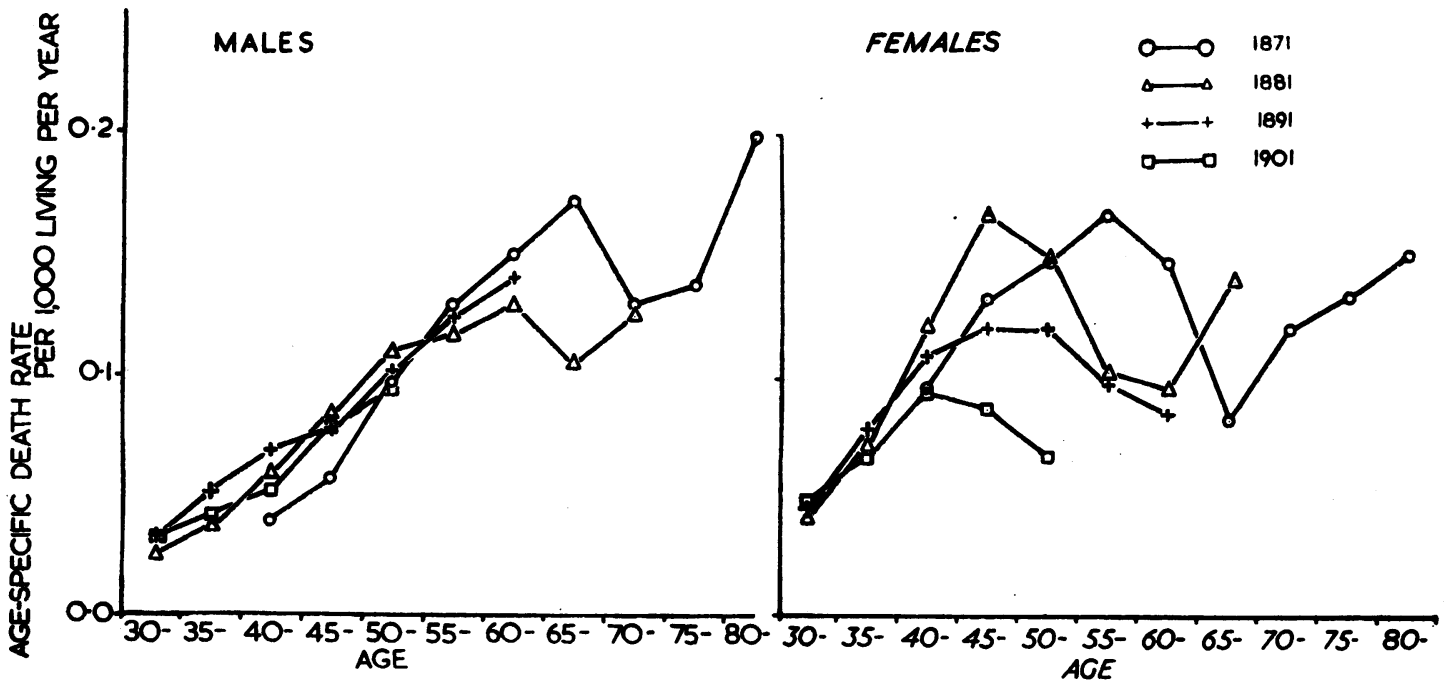

FIG, 30.-Benign Tumours and Tumours of Undetermined Nature. 
Fig. 31, Leukaemia, and Fig. 32, Hodgkin's Disease, (overleaf) are not included under the general heading of cancer because they are not universally accepted as such. In the Appendix
Tables, the total of Cancer at All Sites, Benign Tumours and Tumours of Undetermined Nature, Leukaemia, and Hodgkin's Disease comprise the class called All Neoplasms.

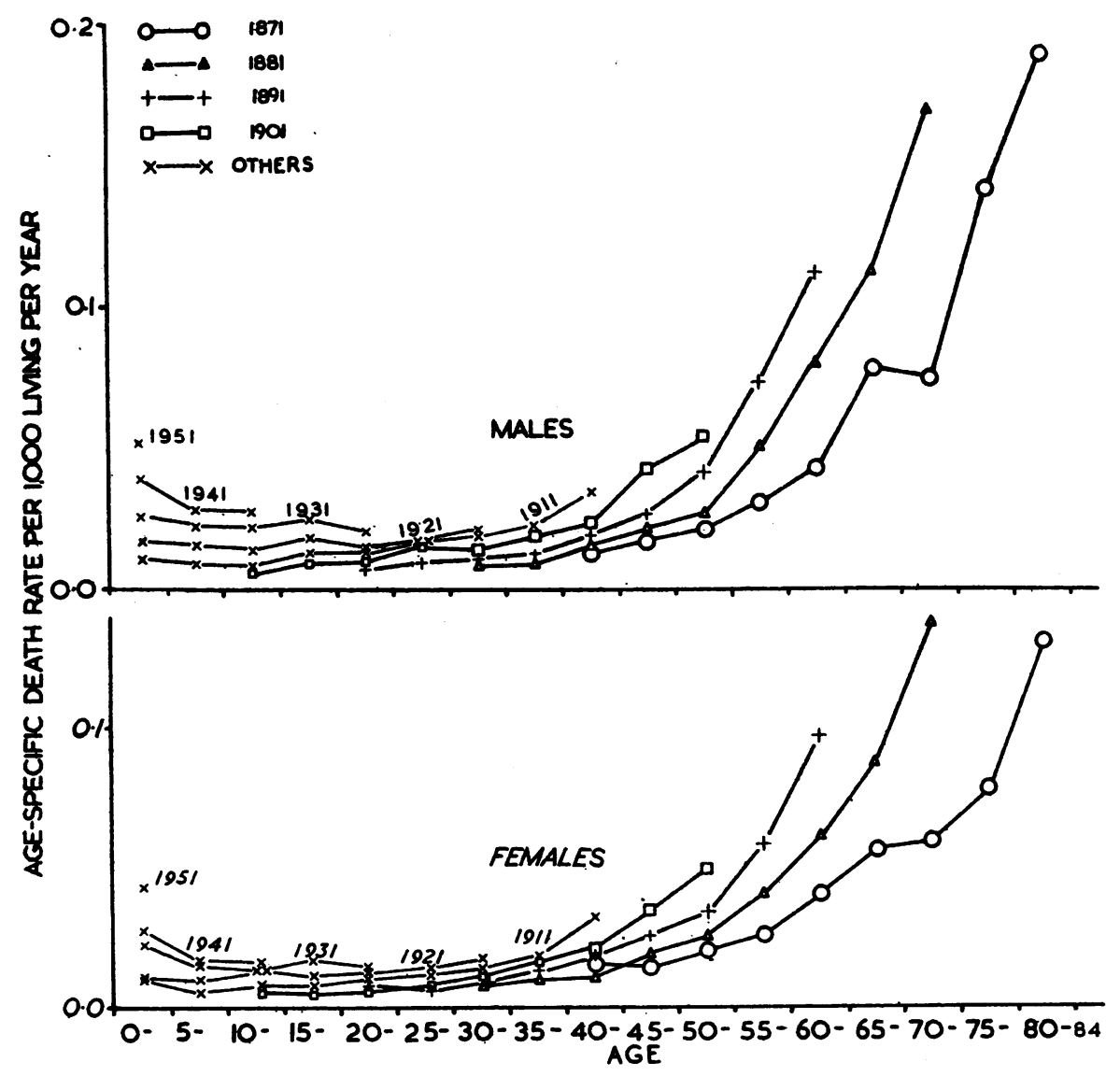

Fig. 31.-Leukaemia (All Types). 


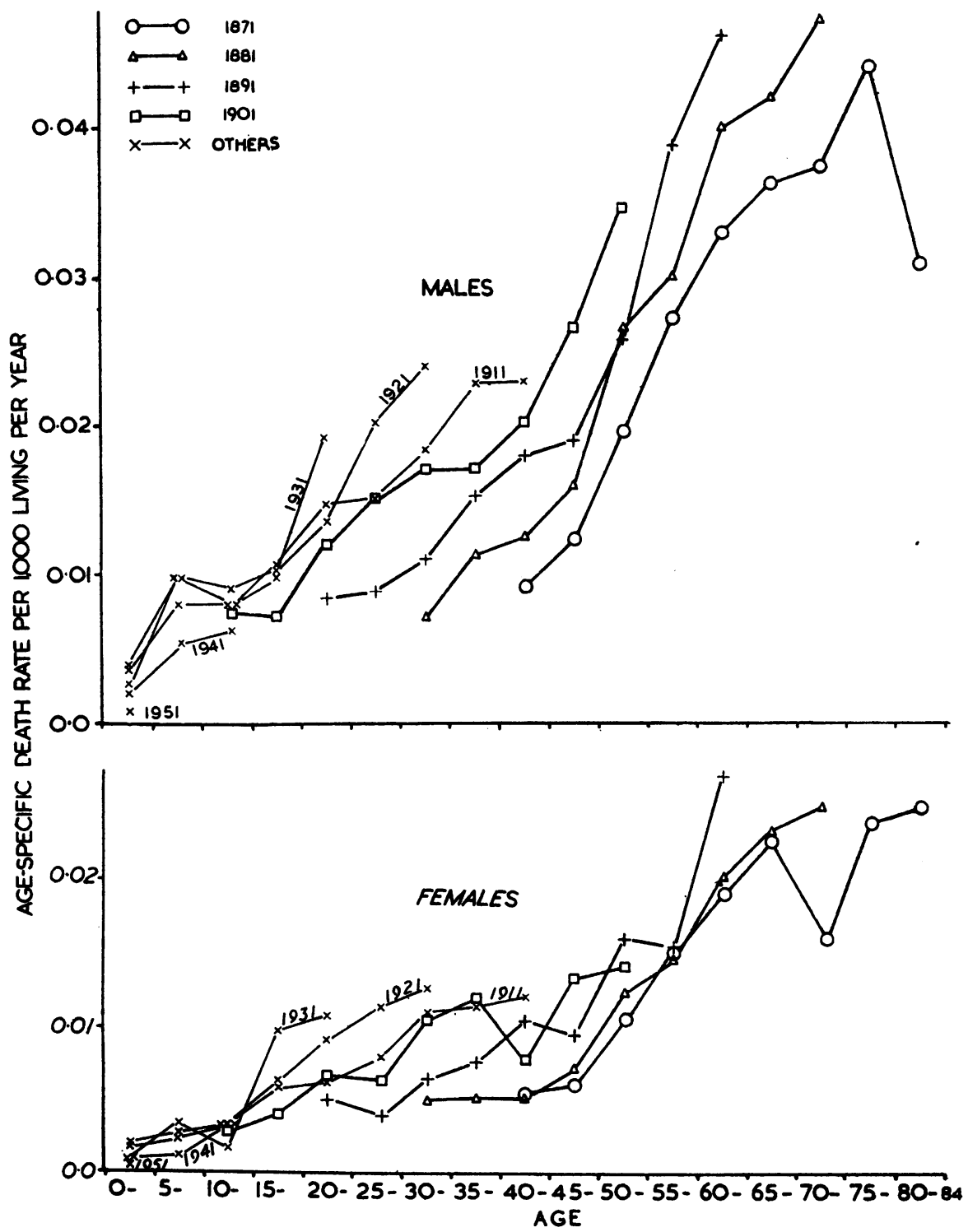

FIG. 32.-Hodgkin's Disease. 
Now that the reader has become familiar with the graphical technique employed, it is unnecessary to comment on the picture for each individual site. It will suffice to group the sites together according to the behaviour of the death rates, and to comment on points of interest in the discussion.

\section{(1) Sites that show a Rising Rate}

(a) Male rise more pronounced.

Lungs (Fig. 5).

Kidneys and Adrenals (Fig. 16).

Urinary Bladder (Fig. 17) for males; female rate started to rise but is now steady.

Pancreas (Fig. 10).

(b) Rise about equal in both sexes.

Leukaemia (Fig. 31).

Hodgkin's Disease (Fig. 32).

(c) Sexual site.

Ovaries and Fallopian Tubes (Fig. 23).

(2) Site that showed a Rising Rate but now shows a Falling Rate

Prostate (Fig. 28).

Additional cohorts are used to show that a rising rate that persisted from at least the 1861 cohort until the 1881 cohort has now been replaced by a falling rate. The inset is the tail of the curve magnified ten times.

\section{(3) Sites that show No Definite Change}

Urinary Bladder (Fig. 17) for females.

Breast (Fig. 22) for males.

Testes (Fig. 26).

\section{(4) Sites that show a Falling Rate}

(a) Male fall more pronounced.

Oesophagus (Fig. 15).

Rectum (Fig. 8).

Tongue (Fig. 11).

Mouth and Tonsils (Fig. 12).

Larynx (Fig. 14).

Pharynx (Fig. 13) for males; female rate rising.

Jaw (Fig. 21).

(b) Female fall more pronounced.

Stomach (Fig. 6).

Intestines (Fig. 7).

Liver and Gall-Bladder (Fig. 9).

Skin, excluding Scrotum (Fig. 18).

Lips (Fig. 19).

Bones, excluding Jaw (Fig. 20).

Breast (Fig. 22) for females; male rate stationary. (c) Sexual sites.

Penis and Scrotum (Fig. 27).

Uterus (Fig. 25).

Vulva and Vagina (Fig. 24).

(5) Site that shows Anomalous Behaviour

Pharynx (Fig. 13); male rate falling, female rate rising.

\section{Discussion}

The changes that are shown in the pictures are changes recorded in the death rates; as such they will reflect the effect of a complex of changing conditions that includes environment, diagnosis, treatment, and social habits. This paper makes no attempt to assess the influence of each of these factors in relation to the mortality changes shown at each site. A complete analysis of this sort may never be achieved, but even a partial one will require a study of the social history of these factors over the relevant period of time. The results of the study must then be correlated with cohort analysis to answer the question: "Could the changes of mortality shown have been due to the particular events that have given rise to some hypothesis of causation?" In this way the narrative properties of the method will be fully exploited.

There are, however, certain features in the graphs that can be discussed profitably even at this stage.

First, the changes in methods of death certification introduced in 1939 may cause discontinuities in the curves between the quinquennia $1936-40$ and 1941-45. One such discontinuity occurs in the picture for female cancer of the breast (Fig. 22). That the kink is in fact an artefact is shown by using part of an additional cohort line for 1866 . The kink that was seen at age 70-74 in the 1871 cohort now moves to age 75-79, corresponding to the year 1940.

Secondly, a peak that moves to different ages in successive cohorts, such as that shown by the Bones, excluding Jaw (Fig. 20) and the Jaw (Fig. 21 ), could reflect a change in either aetiology or therapy that took place at a sharply-defined period of time. In the case of aetiology this time might occur many years before the change shown in the picture. It is interesting to speculate whether a revolution in anaesthesia, surgical technique, and post-operative treatment between about 1936 and 1945 could have produced a dramatic rise in the cure rate, and hence a fall in the death rate, at these sites. Even if these factors could be invoked to explain the shift in the peak, the use of additional cohorts reveals that there was previously a stationary 
peak at an advanced age. A peak at a very advanced age might be of diagnostic origin because of an unwillingness to subject an elderly patient to distressing diagnostic procedures.

Thirdly, when rates are changing, some consideration must be given to the relative changes shown by each sex. Thus, it might be reasonable to attribute the changes in the death rate for, say, the Liver and Gall-Bladder (Fig. 9), which shows a decrease about equal in both sexes, to better allocation of the disease to a primary site, and those in the death rate for Leukaemia (Fig. 31) and Hodgkin's Disease (Fig. 32), which show an increase about equal in both sexes, to improvements in diagnosis; but would it be reasonable to use the same argument in the case of the Lungs (Fig. 5), Urinary Bladder (Fig. 17) and Kidneys and Adrenals (Fig. 16), all of which show a predominantly male rise? A detailed knowledge of how the diagnosis has been made and recorded for each sex at different times is needed to answer this question.

In certain sites, such as the Oesophagus (Fig. 15), Rectum (Fig. 8), Tongue (Fig. 11), Mouth and Tonsils (Fig. 12), and Larynx (Fig. 14), there is a disproportionate fall in the male death rate. Can this be accounted for by a difference in the results of therapy or in the availability of therapy, or should some explanation involving a differentially changed environment be invoked?

Where a substantial fall in death rates for both sexes is shown, do current views of the results of therapy support a contention that the fall is a reflection of therapeutic triumphs or should the reason be sought in an environmental change common to both sexes?

One of the purposes of presenting these studies is to provide part of the basic information necessary to make renewed attempts to answer these complex questions, and to allow other pertinent questions to be formulated. Another purpose is to answer the three questions posed in the introductory paragraphs.

Question 1.-Is the lethal force with which cancer affects the community increasing, and if so what forms of cancer contribute to this increase?

Answer.-In the male, Yes; but if cancer of the Lungs is excluded, No. (Reasons for considering the problem with and without exclusion are given above). In the female, No.

Question 2.-Is there, generally speaking, a "cancerage", or does the force of mortality due to cancer at different sites increase throughout the life-span?

Answer.-In general, no "cancer-age" is found, and the force of mortality increases throughout the life- span. Exceptions to this are cancer of the Uterus and possibly cancer of the Bones, Jaw, and Tongue, where the rates show a decline at advanced ages. Such a late decline may be of diagnostic origin. The curves for cancer of the Testes are too confused to allow a conclusion to be drawn.

Question 3.-Is there a consistent sex-difference in the force of mortality due to cancer at the different sites common to both sexes, and if so how great is this difference?

Answer.-In thirteen of the eighteen sites common to both sexes that were studied, the male showed an equal or higher mortality rate at all the ages analysed. (The lowest age was $\mathbf{3 0}$ in three of the cohorts and $\mathbf{4 0}$ in the other).

At four sites, Larynx, Oesophagus, Intestines, and Liver and Gall-Bladder, the female rate was initially (age 30-59) slightly higher. A male preponderance was established before the age of 45 for the Larynx and Oesophagus, and before the age of 60 for the Intestines and Liver and Gall-Bladder and continued thereafter.

In the remaining site, the Breast, the female had a much higher rate at all ages, but the male organ is vestigial and the comparison unfair.

The sex ratio at ages above 60 varies from about $1 \cdot 2: 1$ to about $10: 1$ for the seventeen sites showing a male preponderance, but the ratio may change from age group to age group and from cohort to cohort.

An unwary reader might be tempted to add together the cancer death rates for males and females and to assert that the constancy shown by this compound figure supports the hypothesis of Cramer (19:6) that the cancer death rate in a community remains constant, and that an alteration of the rate at one site is compensated by a concomitant variation at another site.

From a statistical point of view a concept of this sort can be construed in two ways:

The first is to say that a given individual has a certain tendency to develop cancer, and that if cancer does not appear in one site there is a greater liability for it to appear in another. Although I am unaware of any valid grounds for holding this view, it does not, a priori, appear biologically absurd.

The second is to say that if Person A alters his habits or environment in such a way that he changes the likelihood of his developing cancer, this will affect, in the opposite way, the chances of a Person B developing cancer, the sum of the two likelihoods remaining constant. This is unlikely to commend itself to many scientists as a biological proposition, but it is the construction that must be invoked if the male and female rates are added together and used as evidence of an unchanging cancer mortality. 


\section{SUMMARY}

The death rates for cancer at 21 sites for both males and females in England and Wales are shown in graphical form, analysed by cohort analysis covering the years 1911-1954.

The graphs are intended primarily as an atlas of cancer mortality trends, to serve as a background for further studies of the reasons for these trends.

The death-rate from Cancer at All Sites is rising in males and falling in females. If cancer of the Lungs is excluded, the trend is to fall in both sexes, and the mortality rates at the age of 50-54 affecting persons born around 1901 are 70 per cent. (males) and 80 per cent. (females) of the rates that affected persons born 30 years earlier (i.e. around 1871) at the age of 50-54.

The Lungs, Pancreas, Urinary Bladder in males and the Kidneys and Adrenals, Ovaries and Fallopian Tubes, and Pharynx in females are the only sites of cancer to show a rising death rate. By far the greatest rise is shown by cancer of the Lungs in males. Some sites show a proportionately much greater improvement in the death rate for males than for females.

In general, no "cancer-age" is found, the death rates continuing to rise throughout life. Exceptions to this are cancer of the Uterus, and a very late effect, possibly of diagnostic origin, for cancer of the Bones, the Jaw, and the Tongue.

The male death rates at ages over 60 are always higher than the female death rates for the sites of cancer common to both sexes that were studied. (The Breast forms an exception to this rule, but the male organ is vestigial and the comparison unfair.) Between the ages of $\mathbf{3 0}$ and $\mathbf{4 5}$ for the sites Larynx and Oesophagus and between the ages 30 and 60 for the sites Intestines and Liver and Gall-Bladder, the female rates exceed the male rates. After these ages a male preponderance is established.

The ratio of male to female mortality may change from site to site, age group to age group, and cohort to cohort.
Thanks are due to Miss Joan Pearson (now Mrs. G. Bennette) and to Mrs. W. A. Ward for assembling data and computing rates, and to the Registrar-General's staff for supplying some unpublished data.

This investigation received support from grants to the Chester Beatty Research Institute from the British Empire Cancer Campaign, the Jane Coffin Childs Memorial Fund, the Anna Fuller Fund, and the National Institutes of Health, U.S. Public Health Service.

\section{REFERENCES}

Case, R. A. M. (1956). British Journal of Preventive and Social Medicine, 10, 159 .

and Pearson, J. T. (1955). "Cancer Death-Rates by Site, Age, and Sex, England and Wales, 1911-53". London, Institute of Cancer Research: Royal Cancer Hospital, 1955. Tables. (unpublished).

Clemmesen, J., Nielsen, A., and Jensen, E. (1953). Acta Un. int. Cancr., 9, 603.

Cutler, S. J., and Loveland, D. B. (1954). J. nat. Cancer Inst., 15, 201.

Cramer, W. (1936). In "Reports of the Second International Congress of Scientific and Social Campaign against Cancer", vol. 1, p. 441. Ligue nationale belge contre le cancer, Brussels.

Dorn, H. F. (1953). Acta Un. int. Cancr., 9, 552.

Haenszel, W., and Shimkin, M. B. (1956). J. nat. Cancer Inst., 16, 1417.

Hewitt, D. (1955). British Journal of Preventive and Social Medicine,

H.M. 81. . . Various years. "Manual of the International List of Causes of Death as adapted for use in England and Wales, Scotland and Northern Ireland. Based on the 2nd, 3rd, 4th, and 5th Decennial Revision by the International Commission. Paris". H.M.S.O., London.

$\begin{array}{lllll}\text { 2nd decennial revision } 1909 & \text { publ. } 1912 . \\ \text { 3rd "\# } & \text { " } & 1920 & 1926 . \\ \text { 4th } & \text { " } & 1929 & 1931 .\end{array}$

"Sixth Manual of the International Statistical Classification of Diseases, Injuries and Causes of Death". Sixth Revision of the International Lists of Diseases and Causes of Death. Adopted 1948. World Health Organization, Geneva, Switzerland (publ. W.H.O. in 1948; publ. H.M.S.O. in 1949).

Kennaway, E. L., and Waller, R. E. (1953). Acta Un. int. Cancr., 9, 485.

Kennaway, N. M., and Kennaway, E. L. (1936). J. Hyg. (Camb.), 36, 236.

Korteweg, R. (1951). Brit. J. Cancer, 5, 21.

- (1953). Acta Un. int. Cancr., 9, 529.

Levin, M. L. (1953). Ibid., 9, 531 .

Raven, R. W. (1955). "Cancer and Allied Diseases", p. 23. Duckworth, London.

Registrar-General (1913 to 1922). “Annual Reports of the RegistrarGeneral", vols. 74 to 83 for the years 1911 to 1920 . H.M.S.O., London.

- (1923 to 1955). "Statistical Reviews of England and Wales for the Years 1921-1954". H.M.S.O., London.

- (1944). "Statistical Review of England and Wales for 1939. Tables. Medical", Table 21 and Appendix B.1. H.M.S.O., London.

- (1955). "Supplement on General Morbidity, Cancer, and Mental Health, for 1950-1951". H.M.S.O. London.

Stocks, P. (1953a). Brit. J. Cancer., 7, 407.

- (1953b). Ibid., 7, 283.

Willis, R. A. (1953). "Pathology of Tumours", 2nd. ed., p. 66. Butterworth, London.

\section{APPENDIX}

\section{Details of the Sources of Information for, and the Methods of, Calculating the Rates}

From 1911 until 1949 the successive volumes of the Registrar-General's "Reports" and "Reviews" contained a Table showing the number of deaths from cancer occurring in England and Wales in each year. These cancer deaths were subdivided according to sex, age, and site, and included non-civilians. The Table was always in the "Text" part of the
Report or Review, and was variously called "Sites of Fatal Cancer" (1911-1930), "Forms of Fatal Cancer at Each Site" (1931-1938), and then "Cancer of Different Forms and Sites" (1939-49). In 1950 this Table was discontinued, but subsequently Table 17 of the "Tables (Medical) Section" gave a fairly detailed breakdown of cancer by site. The 
Registrar-General's staff kindly supplied the additional information necessary to reconstruct the remaining relevant sections of the discontinued Table.

Of the 26 sites listed for each sex in 1911, 21 could be followed throughout the ensuing 40 years by careful scrutiny of the Tables and the definitions given in the various manuals based on the "International List of Causes of Death" (H.M.S.O., Various Years), which was revised in 1909, 1920, 1929, 1938, and 1948. In addition to giving the data by sites, the Tables gave figures for Cancer at All Sites. The difference between these figures and the sum of the 21 sites selected for the analysis gave a category "Cancer at All Other Sites" (Fig. 29), which varied from about 5 per cent. to about 10 per cent. of the total according to age and date. In other words the breakdown by sites covered more than 90 per cent. of the total cancer mortality.

Leukaemia, Hodgkin's Disease, and Benign Tumours and Tumours of Undetermined Nature were listed under a variety of titles in the Tables relating to "Causes of Death at Different Age Periods" that appeared in the "Tables Section" of the "Reports" and "Reviews". During some of the war years these Tables excluded non-civilians, but their deaths were listed in a special table, and were added to the totals.

Hodgkin's Disease appeared under the following headings and code numbers:

Lymphadenoma 53b (1911-1920).

Lymphadenoma (Hodgkin's Disease) 65b (1921-30).

Aleukaemia (Lymphadenoma) 72b (1931-38).

Pernicious Lymphogranulomatosis 44b (1939-49).

Hodgkin's Disease 201 (1950 and subsequently).

Leukaemia was listed under the following headings and code numbers:

Leucocythaemia (Leuchaemia) 53a (1911-1920).

Leukaemia 65a (1921-30).

Leukaemia 72a (1931-1938).

Leukaemia and Aleukaemia 74 (1939-1949).

Leukaemia and Aleukaemia 204 (1950 and subsequently).

Benign Tumours and Tumours of Undetermined Nature were listed under this title or one very like it. Tumours of the Central Nervous System and Benign Tumours of the Uterus and Adnexa were added to these figures in those years where they were not already included.
The age breakdown was fairly detailed but inconsistent. The "Cancer by Site" Tables ran 0-, 5-, 15-, 25-, 35-, 40-, 45-, and thereafter in quinary groups until the ultimate group 85 and over. The "Causes of Death at Different Age Periods" ran in quinary groups from birth until an ultimate group of 80 and over in some years or 85 and over in others.

The mid-year population estimates were given in the same series of "Reports" and "Reviews". For some years a Revised Estimate appeared later, when Census returns had made this possible. These revised tables were used when available. Populations designated as "including non-civilians" were used until 1949. Thereafter the populations called "Home Population" were used as being the most appropriate. All these population Tables gave a uniform quinary age breakdown up to an ultimate group of 85 and over.

The data (populations and deaths) were combined into quinquennial groups, 1911-15, 1916-20, and so on. Since the 1955 figures had not become available at the time of writing, the four years 1951, 2, 3, and 4 were used to represent the quinquennium.

The age-specific death rates were calculated by dividing the total number of deaths in each quinary age group in each quinquennium by the sum of the mid-year populations for the appropriate age group and quinquennium. Since the mid-year estimate of the population was a very close approximation to the number of years of life-experience at the stated age in the year, the resulting death rates were the average number of deaths occurring per 1,000 years of life-experience in a specified 5-year age-group during a specified 5-year period.

Correction factors were computed in an agespecific manner by dividing the entries in Table 21 (p. 113) of the "Review" of the Registrar-General (1942) by the corresponding entries in Appendix B.1 (p. 301) of the same volume. Reciprocals of this ratio were also calculated. This gave two agespecific factors that could convert pre-1939 death rates to post-1939 ones or vice versa. In these studies all the rates subsequent to 1939 were converted to pre-1939 rates. The published data were insufficient to allow correction factors to be calculated for all sites. The sites where a factor was obtained are indicated in Appendix Table I.

Rates for the age group 30-34 were in many instances obtained by graphical interpolation because of the change in age-grouping in the published data. Appendix Table I shows where this was done. 
APPENDIX TABLE I

AGE-SPECIFIC DEATH RATES AT AGES 30-84, IN QUINARY GROUPS, FOR THE FOUR MAIN COHORTS BORN AROUND

1871, 1881, 1891, AND 1901

All rates are expressed as rates per 1,000 living per year. Female rates are in italic figures. Male rates are not.

The symbol * indicates that the rates for this age and site were found by curvilinear graphical interpolation from the inconsistently grouped data.

The symbol (C) indicates that a correction factor for the 1939 change in death certification procedure had been applied at this site.

\begin{tabular}{|c|c|c|c|c|c|c|c|c|c|c|c|c|c|}
\hline \multirow{2}{*}{$\begin{array}{l}\text { Fig. } \\
\text { No. }\end{array}$} & \multirow{2}{*}{ Cause of Death } & \multirow{2}{*}{$\begin{array}{c}\text { Cohort } \\
\text { born }\end{array}$} & \multicolumn{11}{|c|}{ Age } \\
\hline & & & 30 & $35-$ & 40 & 45- & 50 & 55 & 60 & $65-$ & 70 & $75-$ & $80-84$ \\
\hline 2 & $\begin{array}{l}\text { All Causes } \\
\text { (General Mortality) }\end{array}$ & $\begin{array}{l}1871 \\
1881 \\
1891 \\
1901\end{array}$ & $\begin{array}{c}\overline{ } \\
5 \cdot 584 \\
4 \cdot 452 \\
4 \cdot 298 \\
3 \cdot 755 \\
3 \cdot 475 \\
3 \cdot 212\end{array}$ & $\begin{array}{c}\overline{7} \\
7 \cdot \overline{800} \\
5 \cdot 952 \\
5 \cdot 242 \\
4 \cdot 168 \\
4 \cdot 234 \\
3 \cdot 373\end{array}$ & $\begin{array}{l}9 \cdot 176 \\
7 \cdot 196 \\
7 \cdot 291 \\
5 \cdot 504 \\
6 \cdot 221 \\
4 \cdot 796 \\
5.035 \\
3 \cdot 703\end{array}$ & \begin{tabular}{|}
$11 \cdot 894$ \\
8.867 \\
9.836 \\
7.007 \\
8.605 \\
$6 \cdot 122$ \\
6.703 \\
4.473
\end{tabular} & $\begin{array}{r}13.425 \\
10.353 \\
13.154 \\
9.361 \\
11.860 \\
7.598 \\
10.552 \\
6.052\end{array}$ & $\begin{array}{c}19 \cdot 673 \\
14 \cdot 331 \\
20 \cdot 101 \\
12 \cdot 869 \\
17 \cdot 423 \\
9.963 \\
=\end{array}$ & $\begin{array}{c}28 \cdot 783 \\
21.074 \\
28 \cdot 227 \\
17 \cdot 190 \\
28 \cdot 542 \\
15.024 \\
=\end{array}$ & $\begin{array}{c}45 \cdot 814 \\
32 \cdot 821 \\
41 \cdot 789 \\
26 \cdot 000 \\
= \\
=\end{array}$ & $\begin{array}{c}64 \cdot 278 \\
46 \cdot 778 \\
68 \cdot 143 \\
43 \cdot 191 \\
= \\
=\end{array}$ & $\begin{array}{c}101 \cdot 751 \\
76 \cdot 904 \\
= \\
= \\
=\end{array}$ & $\begin{array}{c}165 \cdot 668 \\
127 \cdot 025 \\
= \\
= \\
=\end{array}$ \\
\hline - & $\begin{array}{c}\text { All Neoplasms } \\
\text { (C) }\end{array}$ & $\begin{array}{l}1871 \\
1881 \\
1891 \\
1901\end{array}$ & $\begin{array}{l}\overline{-} \\
0.189 \\
0.286 \\
0.198 \\
0.283 \\
0.218 \\
0.292\end{array}$ & $\begin{array}{l}\overline{ } \\
0.317 \\
0.612 \\
0.355 \\
0.614 \\
0.402 \\
0.587\end{array}$ & $\begin{array}{l}0.667 \\
1.212 \\
0.634 \\
1.150 \\
0.675 \\
1.112 \\
0.772 \\
1.029\end{array}$ & $\begin{array}{l}1 \cdot 262 \\
1 \cdot 964 \\
1 \cdot 240 \\
1 \cdot 885 \\
1 \cdot 292 \\
1 \cdot 789 \\
1 \cdot 579 \\
1 \cdot 671\end{array}$ & $\begin{array}{l}2 \cdot 334 \\
2 \cdot 849 \\
2 \cdot 276 \\
2 \cdot 697 \\
2 \cdot 369 \\
2 \cdot 558 \\
2 \cdot 899 \\
2 \cdot 308\end{array}$ & $\begin{array}{c}3 \cdot 896 \\
3 \cdot 751 \\
3 \cdot 837 \\
3 \cdot 581 \\
4 \cdot 296 \\
3 \cdot 371 \\
= \\
-\end{array}$ & $\begin{array}{l}6 \cdot 150 \\
5 \cdot 103 \\
6 \cdot 121 \\
4 \cdot 735 \\
6.980 \\
4 \cdot 372 \\
=\end{array}$ & $\begin{array}{c}8 \cdot 976 \\
6 \cdot 571 \\
9 \cdot 145 \\
6 \cdot 155 \\
= \\
=\end{array}$ & $\begin{array}{c}11 \cdot 979 \\
8 \cdot 319 \\
12 \cdot 826 \\
7 \cdot 794 \\
= \\
=\end{array}$ & $\begin{array}{c}15 \cdot 626 \\
= \\
= \\
= \\
=\end{array}$ & $\begin{array}{c}18 \cdot 869 \\
13 \cdot 354 \\
= \\
= \\
=\end{array}$ \\
\hline 3 & $\begin{array}{c}\text { Cancer at All Sites } \\
\text { (C) }\end{array}$ & $\begin{array}{l}1871 \\
1881 \\
1891 \\
1901\end{array}$ & $\begin{array}{c}\overline{7} \\
0 \cdot 147 \\
0.232 \\
0.145 \\
0 \cdot 224 \\
0.155 \\
0.224\end{array}$ & $\begin{array}{l}\overline{-} \\
0 . \overline{259} \\
0.524 \\
0.276 \\
0.517 \\
0.322 \\
0.488\end{array}$ & $\begin{array}{l}0.605 \\
1.090 \\
0.547 \\
1.023 \\
0.570 \\
0.976 \\
0.677 \\
0.918\end{array}$ & $\begin{array}{l}1 \cdot 175 \\
1.813 \\
1.118 \\
1.694 \\
1.173 \\
1.633 \\
1.432 \\
1.534\end{array}$ & $\begin{array}{l}2 \cdot 198 \\
2 \cdot 670 \\
2 \cdot 111 \\
2 \cdot 509 \\
2 \cdot 200 \\
2 \cdot 391 \\
2 \cdot 690 \\
2 \cdot 187\end{array}$ & $\begin{array}{c}3 \cdot 709 \\
3 \cdot 564 \\
3 \cdot 643 \\
3 \cdot 417 \\
4 \cdot 055 \\
3 \cdot 199 \\
=\end{array}$ & $\begin{array}{l}5.925 \\
4.898 \\
5.871 \\
4.550 \\
6.666 \\
4.161 \\
=\end{array}$ & $\begin{array}{c}8 \cdot 786 \\
6 \cdot 408 \\
8 \cdot 886 \\
5 \cdot 950 \\
= \\
=\end{array}$ & $\begin{array}{c}11 \cdot 739 \\
8 \cdot 122 \\
12 \cdot 483 \\
7 \cdot 490 \\
= \\
=\end{array}$ & $\begin{array}{c}15 \cdot 308 \\
10.615 \\
= \\
= \\
=\end{array}$ & $\begin{array}{c}18 \cdot 457 \\
= \\
= \\
= \\
=\end{array}$ \\
\hline 4 & $\begin{array}{l}\text { Cancer at All Sites except } \\
\text { Lungs } \\
\begin{array}{l}\text { (C) }\end{array}\end{array}$ & $\begin{array}{l}1871 \\
1881 \\
1891 \\
1901\end{array}$ & $\begin{array}{c}\overline{-} \\
0 \cdot 140 \\
0 \cdot 229 \\
0 \cdot 137 \\
0 \cdot 221 \\
0 \cdot 135 \\
0 \cdot 217 \\
=\end{array}$ & $\begin{array}{l}\bar{Z} \\
0.248 \\
0.519 \\
0.254 \\
0.508 \\
0.254 \\
0.472\end{array}$ & $\begin{array}{l}0.588 \\
1.079 \\
0.520 \\
1.011 \\
0.483 \\
0.951 \\
0.484 \\
0.882\end{array}$ & $\begin{array}{l}1.150 \\
1.799 \\
1.042 \\
1.671 \\
0.899 \\
1.584 \\
0.882 \\
1.460\end{array}$ & $\begin{array}{l}2.132 \\
2.644 \\
1.855 \\
2.454 \\
1.597 \\
2.297 \\
1.459 \\
2.052\end{array}$ & $\begin{array}{c}3.561 \\
3.506 \\
3.057 \\
3.310 \\
2.676 \\
3.028 \\
=\end{array}$ & $\begin{array}{c}5 \cdot 565 \\
4 \cdot 780 \\
4 \cdot 840 \\
4 \cdot 276 \\
4.185 \\
3.875 \\
=\end{array}$ & $\begin{array}{c}8 \cdot 150 \\
6 \cdot 229 \\
7 \cdot 066 \\
5 \cdot 642 \\
= \\
=\end{array}$ & $\begin{array}{c}10.968 \\
7.891 \\
9.925 \\
7.105 \\
= \\
= \\
=\end{array}$ & $\begin{array}{c}14 \cdot 212 \\
10 \cdot 300 \\
= \\
= \\
=\end{array}$ & $\begin{array}{c}17.096 \\
12 \cdot 647 \\
= \\
= \\
=\end{array}$ \\
\hline 5 & $\begin{array}{c}\text { Cancer of Lungs } \\
\text { (C) }\end{array}$ & $\begin{array}{l}1871 \\
1881 \\
1891 \\
1901\end{array}$ & $\begin{array}{c}\bar{Z} \\
0.007 \\
0.003 \\
0.008 \\
0.003 \\
0.020 \\
0.007 \\
*\end{array}$ & $\begin{array}{c}\overline{7} \\
0.011 \\
0.005 \\
0.022 \\
0.009 \\
0.068 \\
0.016\end{array}$ & $\begin{array}{l}0.017 \\
0.011 \\
0.027 \\
0.012 \\
0.087 \\
0.025 \\
0.193 \\
0.036\end{array}$ & $\begin{array}{l}0.025 \\
0.014 \\
0.076 \\
0.023 \\
0.274 \\
0.049 \\
0.550 \\
0.074\end{array}$ & $\begin{array}{l}0.066 \\
0.026 \\
0.256 \\
0.055 \\
0.603 \\
0.094 \\
1.231 \\
0.135\end{array}$ & $\begin{array}{c}0.148 \\
0.058 \\
0.586 \\
0.107 \\
1.379 \\
0.171 \\
= \\
-\end{array}$ & $\begin{array}{c}0.360 \\
0.118 \\
1.031 \\
0.174 \\
2.481 \\
0.285 \\
= \\
-\end{array}$ & $\begin{array}{c}0.636 \\
0.179 \\
1.820 \\
0.308 \\
= \\
=\end{array}$ & $\begin{array}{c}0.771 \\
0.231 \\
2.558 \\
0.385 \\
= \\
=\end{array}$ & $\begin{array}{c}1.096 \\
0.315 \\
= \\
= \\
=\end{array}$ & $\begin{array}{c}1.361 \\
0.396 \\
= \\
= \\
=\end{array}$ \\
\hline 6 & $\begin{array}{c}\text { Cancer of Stomach } \\
\text { (C) }\end{array}$ & $\begin{array}{l}1871 \\
1881 \\
1891 \\
1901\end{array}$ & $\begin{array}{c}\overline{-} \\
0.024 \\
0.021 \\
0.029 \\
0.018 \\
0.030 \\
0.023 \\
.\end{array}$ & $\begin{array}{c}\bar{z} \\
0.064 \\
0.051 \\
0.074 \\
0.049 \\
0.077 \\
0.050\end{array}$ & $\begin{array}{l}0.139 \\
0.102 \\
0.156 \\
0.099 \\
0.161 \\
0.095 \\
0.155 \\
0.080\end{array}$ & $\begin{array}{l}0.272 \\
0 \cdot 182 \\
0 \cdot 335 \\
0 \cdot 187 \\
0 \cdot 309 \\
0 \cdot 166 \\
0 \cdot 279 \\
0.132\end{array}$ & $\begin{array}{l}0.515 \\
0.342 \\
0.544 \\
0.313 \\
0.5116 \\
0.254 \\
0.478 \\
0.206\end{array}$ & $\begin{array}{c}0.866 \\
0.538 \\
0.878 \\
0.471 \\
0.836 \\
0.381 \\
= \\
-\end{array}$ & $\begin{array}{c}1.354 \\
0.845 \\
1.310 \\
0.736 \\
1.274 \\
0.538 \\
=\end{array}$ & $\begin{array}{c}1.958 \\
1.253 \\
1.847 \\
1.055 \\
= \\
=\end{array}$ & $\begin{array}{c}2.405 \\
1.595 \\
2.431 \\
1.365 \\
= \\
=\end{array}$ & $\begin{array}{c}2 \cdot 946 \\
2 \cdot 174 \\
= \\
= \\
=\end{array}$ & $\begin{array}{c}3 \cdot 178 \\
2 \cdot 704 \\
= \\
= \\
=\end{array}$ \\
\hline 7 & $\begin{array}{l}\text { Cancer of Intestines } \\
\text { (C) }\end{array}$ & $\begin{array}{l}1871 \\
1881 \\
1891 \\
1901\end{array}$ & $\begin{array}{c}\overline{7} \\
0.019 \\
0.021 \\
0.019 \\
0.020 \\
0.017 \\
0.022 \\
*\end{array}$ & $\begin{array}{c}\overline{-} \\
0.030 \\
0.034 \\
0.033 \\
0.036 \\
0.031 \\
0.045\end{array}$ & $\begin{array}{l}0.058 \\
0.072 \\
0.062 \\
0.071 \\
0.058 \\
0.071 \\
0.079 \\
0.084\end{array}$ & $\begin{array}{l}0 \cdot 111 \\
0 \cdot 138 \\
0 \cdot 114 \\
0 \cdot 140 \\
0 \cdot 110 \\
O \cdot 144 \\
0 \cdot 114 \\
0 \cdot 136\end{array}$ & $\begin{array}{l}0.204 \\
0.252 \\
0.203 \\
0.224 \\
0.201 \\
0.234 \\
0.162 \\
0.186\end{array}$ & $\begin{array}{l}0.421 \\
0.412 \\
0.391 \\
0.371 \\
0.337 \\
0.343 \\
= \\
=\end{array}$ & $\begin{array}{c}0.655 \\
0.596 \\
0.696 \\
0.609 \\
0.472 \\
0.470 \\
=\end{array}$ & $\begin{array}{c}1 \cdot 170 \\
0 \cdot 968 \\
1 \cdot 009 \\
0.848 \\
= \\
=\end{array}$ & $\begin{array}{c}1.743 \\
1.470 \\
1.421 \\
1.096 \\
= \\
=\end{array}$ & $\begin{array}{c}2 \cdot 372 \\
2 \cdot 049 \\
= \\
= \\
= \\
=\end{array}$ & $\begin{array}{c}2 \cdot 680 \\
2.437 \\
= \\
= \\
=\end{array}$ \\
\hline
\end{tabular}

-contin. 
APPENDIX TABLE I (contin.)

\begin{tabular}{|c|c|c|c|c|c|c|c|c|c|c|c|c|c|}
\hline \multirow{2}{*}{$\begin{array}{l}\text { Fig. } \\
\text { No. }\end{array}$} & \multirow{2}{*}{ Cause of Death } & \multirow{2}{*}{$\begin{array}{l}\text { Cohort } \\
\text { born }\end{array}$} & \multicolumn{11}{|c|}{ Age } \\
\hline & & & $30-$ & 35- & 40 & $45-$ & 50 & $55-$ & 60 & $65-$ & $70-$ & $75-$ & $80-84$ \\
\hline 8 & $\begin{array}{c}\text { Cancer of Rectum } \\
\text { (C) }\end{array}$ & $\begin{array}{l}1871 \\
1881 \\
1891 \\
1901\end{array}$ & $\begin{array}{l}- \\
0.016 \\
0.016 \\
0.015 \\
0.015 \\
0.016 \\
0.012 \\
*\end{array}$ & $\begin{array}{c}- \\
0 . \overline{026} \\
0.027 \\
0.021 \\
0.021 \\
0.023 \\
0.025\end{array}$ & $\begin{array}{l}0.056 \\
0.048 \\
0.045 \\
0.049 \\
0.046 \\
0.042 \\
0.052 \\
0.042\end{array}$ & $\begin{array}{l}0.101 \\
0.084 \\
0.092 \\
0.072 \\
0.082 \\
0.071 \\
0.082 \\
0.070\end{array}$ & $\begin{array}{l}0 \cdot 208 \\
0 \cdot 135 \\
0 \cdot 187 \\
0 \cdot 110 \\
0 \cdot 169 \\
0 \cdot 122 \\
0 \cdot 130 \\
0 \cdot 100\end{array}$ & $\begin{array}{c}0.375 \\
0 \cdot 206 \\
0.350 \\
0.189 \\
0.296 \\
0.179 \\
-\end{array}$ & $\begin{array}{c}0.659 \\
0.312 \\
0.605 \\
0.290 \\
0.415 \\
0.242 \\
-\end{array}$ & $\begin{array}{c}1.027 \\
0.418 \\
0.906 \\
0.396 \\
= \\
= \\
=\end{array}$ & $\begin{array}{c}1.487 \\
0.618 \\
1.149 \\
0.497 \\
= \\
= \\
=\end{array}$ & $\begin{array}{c}1.875 \\
0.832 \\
= \\
= \\
= \\
=\end{array}$ & $\begin{array}{c}2.086 \\
0.994 \\
= \\
= \\
= \\
=\end{array}$ \\
\hline 9 & $\begin{array}{l}\text { Cancer of Liver and Gall- } \\
\text { Bladder } \\
\text { (C) }\end{array}$ & $\begin{array}{l}1871 \\
1881 \\
1891 \\
1901\end{array}$ & $\begin{array}{c}-\overline{-} \\
0.009 \\
0.011 \\
0.008 \\
0.008 \\
0.005 \\
0.004 \\
*\end{array}$ & $\begin{array}{c}- \\
0 . \overline{022} \\
0.026 \\
0.010 \\
0.013 \\
0.009 \\
0.010\end{array}$ & $\begin{array}{l}0.050 \\
0.066 \\
0.036 \\
0.040 \\
0.024 \\
0.025 \\
0.019 \\
0.019\end{array}$ & $\begin{array}{l}0.099 \\
0.119 \\
0.058 \\
0.063 \\
0.039 \\
0.040 \\
0.037 \\
0.030\end{array}$ & $\begin{array}{l}0.152 \\
0.164 \\
0.090 \\
0.094 \\
0.072 \\
0.069 \\
0.055 \\
0.050\end{array}$ & $\begin{array}{c}0 \cdot 201 \\
0.216 \\
0.142 \\
0.144 \\
0.105 \\
0.088 \\
-\end{array}$ & $\begin{array}{c}0 \cdot 297 \\
0 \cdot 290 \\
0 \cdot 214 \\
0.196 \\
0.162 \\
0.132 \\
-\end{array}$ & $\begin{array}{c}0.364 \\
0.347 \\
0.257 \\
0.241 \\
= \\
= \\
-\end{array}$ & $\begin{array}{c}0.445 \\
0.448 \\
0.320 \\
0.284 \\
= \\
= \\
=\end{array}$ & $\begin{array}{c}0.449 \\
0.458 \\
= \\
= \\
= \\
=\end{array}$ & $\begin{array}{c}0.512 \\
0.477 \\
= \\
= \\
= \\
=\end{array}$ \\
\hline 10 & $\begin{array}{c}\text { Cancer of Pancreas } \\
\text { (C) }\end{array}$ & $\begin{array}{l}1871 \\
1881 \\
1891 \\
1901\end{array}$ & $\begin{array}{c}- \\
0.004 \\
0.002 \\
0.005 \\
0.003 \\
0.004 \\
0.003 \\
*\end{array}$ & $\begin{array}{c}-\overline{-} \\
0.007 \\
0.005 \\
0.009 \\
0.007 \\
0.007 \\
0.005\end{array}$ & $\begin{array}{l}0.015 \\
0.010 \\
0.018 \\
0.012 \\
0.020 \\
0.015 \\
0.021 \\
0.013\end{array}$ & $\begin{array}{l}0.027 \\
0.019 \\
0.043 \\
0.026 \\
0.043 \\
0.029 \\
0.049 \\
0.025\end{array}$ & $\begin{array}{l}0.059 \\
0.043 \\
0.084 \\
0.051 \\
0.087 \\
0.050 \\
0.091 \\
0.054\end{array}$ & $\begin{array}{c}0.120 \\
0.087 \\
0.131 \\
0.093 \\
0.148 \\
0.098 \\
- \\
-\end{array}$ & $\begin{array}{c}0 \cdot 185 \\
0 \cdot 145 \\
0 \cdot 201 \\
0 \cdot 139 \\
0 \cdot 261 \\
0 \cdot 143 \\
-\end{array}$ & $\begin{array}{c}0 \cdot 293 \\
0 \cdot 214 \\
0.333 \\
0.226 \\
= \\
= \\
=\end{array}$ & $\begin{array}{c}0.388 \\
0.270 \\
0.518 \\
0.322 \\
- \\
- \\
-\end{array}$ & $\begin{array}{c}0.574 \\
0.398 \\
= \\
= \\
= \\
=\end{array}$ & $\begin{array}{c}0.736 \\
0.523 \\
= \\
= \\
= \\
=\end{array}$ \\
\hline 11 & $\begin{array}{c}\text { Cancer of Tonguc } \\
\text { (C) }\end{array}$ & $\begin{array}{l}1871 \\
1881 \\
1891 \\
1901\end{array}$ & $\begin{array}{c}- \\
\overline{0} . \overline{002} \\
0.001 \\
0.002 \\
0.001 \\
0.001 \\
0.001 \\
*\end{array}$ & $\begin{array}{c}-\overline{-} \\
0.005 \\
0.002 \\
0.003 \\
0.002 \\
0.001 \\
0.002\end{array}$ & $\begin{array}{l}0.036 \\
0.004 \\
0.018 \\
0.003 \\
0.005 \\
0.002 \\
0.003 \\
0.002\end{array}$ & $\begin{array}{l}0.080 \\
0.009 \\
0.040 \\
0.006 \\
0.013 \\
0.004 \\
0.005 \\
0.004\end{array}$ & $\begin{array}{l}0.142 \\
0.008 \\
0.062 \\
0.008 \\
0.023 \\
0.009 \\
0.009 \\
0.006\end{array}$ & $\begin{array}{c}0.205 \\
0.016 \\
0.088 \\
0.013 \\
0.035 \\
0.009 \\
-\end{array}$ & $\begin{array}{c}0.269 \\
0.023 \\
0.128 \\
0.017 \\
0.046 \\
0.014 \\
-\end{array}$ & $\begin{array}{c}0 \cdot 297 \\
0.027 \\
0 \cdot 140 \\
0.024 \\
= \\
= \\
=\end{array}$ & $\begin{array}{c}0.355 \\
0.039 \\
0.171 \\
0.035 \\
= \\
= \\
=\end{array}$ & $\begin{array}{c}0.343 \\
0.053 \\
= \\
= \\
= \\
=\end{array}$ & $\begin{array}{c}0.339 \\
0.059 \\
= \\
= \\
= \\
=\end{array}$ \\
\hline 12 & $\begin{array}{l}\text { Cancer of Mouth and } \\
\text { Tonsils }\end{array}$ & $\begin{array}{l}1871 \\
1881 \\
1891 \\
1901\end{array}$ & $\begin{array}{c}-\bar{C} \\
0.002 \\
0.001 \\
0.001 \\
0.001 \\
0.002 \\
0.000 \\
*\end{array}$ & $\begin{array}{c}-\overline{-} \\
0.003 \\
0.002 \\
0.004 \\
0.001 \\
0.002 \\
0.002\end{array}$ & $\begin{array}{l}0.015 \\
0.002 \\
0.010 \\
0.002 \\
0.004 \\
0.003 \\
0.002 \\
0.001\end{array}$ & $\begin{array}{l}0.036 \\
0.007 \\
0.026 \\
0.006 \\
0.009 \\
0.002 \\
0.005 \\
0.002\end{array}$ & $\begin{array}{l}0.078 \\
0.008 \\
0.034 \\
0.007 \\
0.013 \\
0.003 \\
0.014 \\
0.005\end{array}$ & $\begin{array}{c}0.137 \\
0.012 \\
0.048 \\
0.008 \\
0.020 \\
0.008 \\
-\end{array}$ & $\begin{array}{c}0.145 \\
0.013 \\
0.064 \\
0.009 \\
0.040 \\
0.013 \\
-\end{array}$ & $\begin{array}{c}0.173 \\
0.019 \\
0.083 \\
0.012 \\
= \\
- \\
-\end{array}$ & $\begin{array}{c}0.178 \\
0.019 \\
0.160 \\
0.024 \\
= \\
= \\
=\end{array}$ & $\begin{array}{c}0.196 \\
0.030 \\
= \\
= \\
= \\
=\end{array}$ & $\begin{array}{c}0.345 \\
0.058 \\
= \\
= \\
= \\
=\end{array}$ \\
\hline 13 & Cancer of Pharynx & $\begin{array}{l}1871 \\
1881 \\
1891 \\
1901\end{array}$ & $\begin{array}{c}- \\
0 . \overline{001} \\
0.001 \\
0.001 \\
0.001 \\
0.001 \\
0.001 \\
*\end{array}$ & $\begin{array}{c}-\overline{-} \\
0.002 \\
0.003 \\
0.002 \\
0.002 \\
0.002 \\
0.002\end{array}$ & $\begin{array}{l}0.007 \\
0.005 \\
0.005 \\
0.006 \\
0.003 \\
0.003 \\
0.006 \\
0.003\end{array}$ & $\begin{array}{l}0.020 \\
0.009 \\
0.014 \\
0.007 \\
0.010 \\
0.007 \\
0.009 \\
0.007\end{array}$ & $\begin{array}{l}0.032 \\
0.012 \\
0.028 \\
0.010 \\
0.018 \\
0.010 \\
0.016 \\
0.019\end{array}$ & $\begin{array}{c}0.059 \\
0.010 \\
0.038 \\
0.016 \\
0.025 \\
0.016 \\
-\end{array}$ & $\begin{array}{c}0.095 \\
0.016 \\
0.062 \\
0.013 \\
0.049 \\
0.030 \\
- \\
-\end{array}$ & $\begin{array}{c}0.124 \\
0.023 \\
0.078 \\
0.024 \\
= \\
= \\
=\end{array}$ & $\begin{array}{c}0.137 \\
0.023 \\
0.124 \\
0.043 \\
= \\
= \\
=\end{array}$ & $\begin{array}{l}0.159 \\
0.030 \\
= \\
= \\
= \\
=\end{array}$ & $\begin{array}{l}0.196 \\
0.042 \\
= \\
= \\
= \\
=\end{array}$ \\
\hline 14 & $\begin{array}{c}\text { Cancer of Larynx } \\
\text { (C) }\end{array}$ & $\begin{array}{l}1871 \\
1881 \\
1891 \\
1901\end{array}$ & $\begin{array}{c}- \\
\overline{0} \cdot \overline{001} \\
0 \cdot 003 \\
0.001 \\
0.002 \\
0.001 \\
0.002 \\
*\end{array}$ & $\begin{array}{c}-\overline{-} \\
0.003 \\
0.006 \\
0.004 \\
0.005 \\
0.003 \\
0.005\end{array}$ & $\begin{array}{l}0.016 \\
0.010 \\
0.015 \\
0.013 \\
0.010 \\
0.009 \\
0.009 \\
0.007\end{array}$ & $\begin{array}{l}0.044 \\
0.023 \\
0.035 \\
0.020 \\
0.024 \\
0.014 \\
0.024 \\
0.012\end{array}$ & $\begin{array}{l}0.097 \\
0.026 \\
0.073 \\
0.029 \\
0.043 \\
0.027 \\
0.036 \\
0.013\end{array}$ & $\begin{array}{l}0.158 \\
0.039 \\
0.117 \\
0.034 \\
0.083 \\
0.027 \\
=\end{array}$ & $\begin{array}{c}0.229 \\
0.037 \\
0.163 \\
0.039 \\
0.116 \\
0.023 \\
-\end{array}$ & $\begin{array}{c}0.295 \\
0.047 \\
0.207 \\
0.039 \\
= \\
= \\
=\end{array}$ & $\begin{array}{c}0.351 \\
0.048 \\
0.248 \\
0.036 \\
= \\
= \\
=\end{array}$ & $\begin{array}{l}0.344 \\
0.062 \\
= \\
= \\
= \\
=\end{array}$ & $\begin{array}{c}0.396 \\
0.044 \\
= \\
= \\
= \\
=\end{array}$ \\
\hline 15 & $\begin{array}{l}\text { Cancer of Oesophagus } \\
\text { (C) }\end{array}$ & $\begin{array}{l}1871 \\
1881 \\
1891 \\
1901\end{array}$ & $\begin{array}{c}- \\
0 . \overline{002} \\
0.005 \\
0.002 \\
0.003 \\
0.002 \\
0.002\end{array}$ & $\begin{array}{c}-\bar{Z} \\
0.005 \\
0.011 \\
0.004 \\
0.008 \\
0.006 \\
0.005\end{array}$ & $\begin{array}{l}0.035 \\
0.025 \\
0.018 \\
0.020 \\
0.012 \\
0.015 \\
0.015 \\
0.010\end{array}$ & $\begin{array}{l}0.091 \\
0.038 \\
0.053 \\
0.030 \\
0.026 \\
0.026 \\
0.027 \\
0.018\end{array}$ & $\begin{array}{l}0.197 \\
0.062 \\
0.107 \\
0.055 \\
0.062 \\
0.038 \\
0.054 \\
0.032\end{array}$ & $\begin{array}{c}0.297 \\
0.072 \\
0.193 \\
0.070 \\
0.114 \\
0.063 \\
=\end{array}$ & $\begin{array}{c}0.457 \\
0.114 \\
0.260 \\
0.099 \\
0.185 \\
0.085 \\
-\end{array}$ & $\begin{array}{c}0.560 \\
0 \cdot 144 \\
0 \cdot 370 \\
0 \cdot 135 \\
= \\
= \\
=\end{array}$ & $\begin{array}{c}0.621 \\
0.168 \\
0.475 \\
0.196 \\
= \\
= \\
=\end{array}$ & $\begin{array}{c}0.789 \\
0.261 \\
= \\
= \\
= \\
=\end{array}$ & $\begin{array}{c}0.857 \\
0.338 \\
= \\
= \\
= \\
=\end{array}$ \\
\hline
\end{tabular}


APPENDIX TABLE I (contin.)

\begin{tabular}{|c|c|c|c|c|c|c|c|c|c|c|c|c|c|}
\hline \multirow{2}{*}{ Fig. } & \multirow{2}{*}{ Cause of Death } & \multirow{2}{*}{$\begin{array}{c}\text { Cohort } \\
\text { born }\end{array}$} & \multicolumn{11}{|c|}{ Age } \\
\hline & & & 30 & 35- & 40 & 45- & 50 & 55 & 60 & 65 & 70 & 75- & 80-84 \\
\hline 16 & $\begin{array}{l}\text { Cancer of Kidneys and } \\
\text { Adrenals }\end{array}$ & $\begin{array}{l}1871 \\
1881 \\
1891 \\
1901\end{array}$ & $\begin{array}{l}\overline{7} \\
0 \cdot 003 \\
0 \cdot 002 \\
0.003 \\
0 \cdot 003 \\
0 \cdot 005 \\
0.003\end{array}$ & $\begin{array}{c}\overline{-} \\
0.005 \\
0.004 \\
0.007 \\
0.003 \\
0.008 \\
0.004\end{array}$ & $\begin{array}{l}0.008 \\
0.007 \\
0.010 \\
0.008 \\
0.015 \\
0.008 \\
0.013 \\
0.008\end{array}$ & $\begin{array}{l}0.015 \\
0.010 \\
0.019 \\
0.011 \\
0.025 \\
0.014 \\
0.029 \\
0.013\end{array}$ & $\begin{array}{l}0.027 \\
0.018 \\
0.035 \\
0.024 \\
0.038 \\
0.020 \\
0.054 \\
0.021\end{array}$ & $\begin{array}{c}0.051 \\
0.027 \\
0.049 \\
0.031 \\
0.069 \\
0.030 \\
=\end{array}$ & $\begin{array}{l}0.073 \\
0.045 \\
0.073 \\
0.039 \\
0.112 \\
0.048 \\
=\end{array}$ & $\begin{array}{c}0.086 \\
0.056 \\
0.106 \\
0.057 \\
= \\
=\end{array}$ & $\begin{array}{l}0.081 \\
0.059 \\
0.147 \\
0.085 \\
= \\
= \\
=\end{array}$ & $\begin{array}{l}0.111 \\
0.085 \\
= \\
= \\
=\end{array}$ & $\begin{array}{l}0.130 \\
0.115 \\
= \\
= \\
= \\
=\end{array}$ \\
\hline 17 & Cancer of Urinary Bladder & $\begin{array}{l}1871 \\
1881 \\
1891 \\
1901\end{array}$ & $\begin{array}{l}\overline{-} \\
0.002 \\
0.001 \\
0.001 \\
0.001 \\
0.002 \\
0.001 \\
.0\end{array}$ & $\begin{array}{c}- \\
0.005 \\
0.004 \\
0.006 \\
0.002 \\
0.005 \\
0.003\end{array}$ & $\begin{array}{l}0.013 \\
0.004 \\
0.012 \\
0.006 \\
0.013 \\
0.006 \\
0.012 \\
0.007\end{array}$ & $\begin{array}{l}0.024 \\
0.010 \\
0.021 \\
0.014 \\
0.034 \\
0.010 \\
0.039 \\
0.014\end{array}$ & $\begin{array}{l}0.048 \\
0.022 \\
0.062 \\
0.018 \\
0.079 \\
0.028 \\
0.088 \\
0.025\end{array}$ & $\begin{array}{c}0.100 \\
0.036 \\
0.114 \\
0.040 \\
0.143 \\
0.041 \\
=\end{array}$ & $\begin{array}{c}0.183 \\
0.059 \\
0.220 \\
0.082 \\
0.272 \\
0.064 \\
=\end{array}$ & $\begin{array}{c}0.285 \\
0.106 \\
0.355 \\
0.130 \\
= \\
=\end{array}$ & $\begin{array}{c}0.443 \\
0.166 \\
0.586 \\
0.167 \\
= \\
= \\
=\end{array}$ & $\begin{array}{l}0.665 \\
0.239 \\
= \\
= \\
= \\
=\end{array}$ & $\begin{array}{l}0.941 \\
0.346 \\
= \\
= \\
=\end{array}$ \\
\hline 18 & $\begin{array}{l}\text { Cancer of Skin (excluding } \\
\text { Scrotum) } \\
\text { (C) }\end{array}$ & $\begin{array}{l}1871 \\
1881 \\
1891 \\
1901\end{array}$ & $\begin{array}{c}\overline{-} \\
0.004 \\
0.002 \\
0.004 \\
0.003 \\
0.004 \\
0.003 \\
\end{array}$ & $\begin{array}{c}\overline{-} \\
0.006 \\
0.004 \\
0.006 \\
0.006 \\
0.004 \\
0.005\end{array}$ & $\begin{array}{l}0.020 \\
0.008 \\
0.009 \\
0.010 \\
0.007 \\
0.006 \\
0.007 \\
0.009\end{array}$ & $\begin{array}{l}0.021 \\
0.013 \\
0.015 \\
0.011 \\
00.016 \\
0.013 \\
0.015 \\
0.011\end{array}$ & $\begin{array}{l}0.030 \\
0.022 \\
0.026 \\
0.018 \\
0.020 \\
0.016 \\
0.020 \\
0.012\end{array}$ & $\begin{array}{c}0.055 \\
0.031 \\
0.041 \\
0.025 \\
0.028 \\
0.021 \\
= \\
=\end{array}$ & $\begin{array}{c}0.075 \\
0.042 \\
0.063 \\
0.032 \\
0.046 \\
0.029 \\
=\end{array}$ & $\begin{array}{c}0.123 \\
0.060 \\
0.100 \\
0.052 \\
= \\
=\end{array}$ & $\begin{array}{c}0.216 \\
0.090 \\
0.133 \\
0.072 \\
= \\
=\end{array}$ & $\begin{array}{l}0.301 \\
0.178 \\
= \\
= \\
=\end{array}$ & $\begin{array}{l}0.477 \\
0.231 \\
= \\
= \\
= \\
=\end{array}$ \\
\hline 19 & $\begin{array}{l}\text { Cancer of Lips } \\
\text { (C) }\end{array}$ & $\begin{array}{l}1871 \\
1881 \\
1891 \\
1901\end{array}$ & $\begin{array}{c}\overline{\bar{c}} \\
0.000 \\
0.000 \\
0.000 \\
0.000 \\
0.000 \\
0.000 \\
00\end{array}$ & $\begin{array}{c}\overline{-} \\
0.001 \\
0.000 \\
0.001 \\
0.000 \\
0.000 \\
0.000\end{array}$ & $\begin{array}{l}0.003 \\
0.000 \\
0.002 \\
0.000 \\
0.002 \\
0.000 \\
0.001 \\
0.000\end{array}$ & $\begin{array}{l}0.007 \\
0.001 \\
0.005 \\
0.001 \\
0.003 \\
0.000 \\
0.002 \\
0.000\end{array}$ & $\begin{array}{l}0.012 \\
0.001 \\
0.010 \\
0.001 \\
0.004 \\
0.000 \\
0.001 \\
0.000\end{array}$ & $\begin{array}{c}0.026 \\
0.001 \\
0.016 \\
0.001 \\
0.006 \\
0.001 \\
=\end{array}$ & $\begin{array}{c}0.040 \\
0.002 \\
0.021 \\
0.002 \\
0.009 \\
0.001 \\
= \\
=\end{array}$ & $\begin{array}{c}0.056 \\
0.004 \\
0.027 \\
0.002 \\
= \\
=\end{array}$ & $\begin{array}{c}0.089 \\
0.004 \\
0.037 \\
0.004 \\
= \\
=\end{array}$ & $\begin{array}{c}0 \cdot 109 \\
0.005 \\
= \\
= \\
=\end{array}$ & $\begin{array}{l}0 \cdot 135 \\
0 \cdot 008 \\
= \\
= \\
= \\
\end{array}$ \\
\hline 20 & $\begin{array}{l}\text { Cancer of Bones (exclud- } \\
\text { ing Jaw) } \\
\text { (C) }\end{array}$ & $\begin{array}{l}1871 \\
1881 \\
1891 \\
1901\end{array}$ & $\begin{array}{c}\overline{-} \\
0 \cdot 009 \\
0 \cdot 006 \\
0 \cdot 009 \\
0.007 \\
0 \cdot 009 \\
0.007 \\
*\end{array}$ & $\begin{array}{l}\overline{ } \\
0 . \overline{0} 11 \\
0.007 \\
0.012 \\
0.009 \\
0.011 \\
0.009\end{array}$ & $\begin{array}{l}0.016 \\
0.009 \\
0.014 \\
0.016 \\
0.013 \\
0.014 \\
0.016 \\
0.013\end{array}$ & $\begin{array}{l}0.023 \\
0.020 \\
0.024 \\
0.020 \\
0.022 \\
0.016 \\
0.020 \\
0.014\end{array}$ & $\begin{array}{l}0.029 \\
0.028 \\
0.039 \\
0.029 \\
0.041 \\
0.028 \\
0.025 \\
0.015\end{array}$ & $\begin{array}{c}0.050 \\
0.038 \\
0.052 \\
0.038 \\
0.051 \\
0.031 \\
=\end{array}$ & $\begin{array}{l}0.063 \\
0.045 \\
0.081 \\
0.048 \\
0.055 \\
0.034 \\
=\end{array}$ & $\begin{array}{c}0.090 \\
0.063 \\
0.079 \\
0.056 \\
= \\
=\end{array}$ & $\begin{array}{c}0.110 \\
0.065 \\
0.082 \\
0.044 \\
= \\
=\end{array}$ & $\begin{array}{l}0 \cdot 129 \\
0 \cdot 105 \\
= \\
= \\
=\end{array}$ & $\begin{array}{l}0.102 \\
0.083 \\
= \\
= \\
= \\
=\end{array}$ \\
\hline 21 & Cancer of Jaw & $\begin{array}{l}1871 \\
1881 \\
1891 \\
1901\end{array}$ & $\begin{array}{c}\bar{z} \\
0.003 \\
0.002 \\
0.002 \\
0.002 \\
0.002 \\
0.002 \\
*\end{array}$ & $\begin{array}{l}- \\
0.007 \\
0.005 \\
0.004 \\
0.003 \\
0.002 \\
0.002\end{array}$ & $\begin{array}{l}0.016 \\
0.009 \\
0.008 \\
0.005 \\
0.007 \\
0.004 \\
0.002 \\
0.002\end{array}$ & $\begin{array}{l}0.033 \\
0.011 \\
0.019 \\
0.009 \\
0.011 \\
0.007 \\
0.004 \\
0.002\end{array}$ & $\begin{array}{l}0.053 \\
0.017 \\
0.028 \\
0.015 \\
0.012 \\
0.007 \\
0.004 \\
0.003\end{array}$ & $\begin{array}{l}0.075 \\
0.026 \\
0.041 \\
0.016 \\
0.012 \\
0.007 \\
=\end{array}$ & $\begin{array}{c}0.081 \\
0.035 \\
0.040 \\
0.011 \\
0.008 \\
0.006 \\
=\end{array}$ & $\begin{array}{c}0.101 \\
0 \cdot 038 \\
0.041 \\
0.011 \\
= \\
=\end{array}$ & $\begin{array}{c}0.102 \\
0.027 \\
0.031 \\
0.013 \\
= \\
=\end{array}$ & $\begin{array}{c}0.090 \\
0.029 \\
= \\
= \\
=\end{array}$ & $\begin{array}{l}0.059 \\
0.018 \\
= \\
= \\
= \\
\end{array}$ \\
\hline 22 & $\begin{array}{c}\text { Cancer of Breast } \\
\text { (C) }\end{array}$ & $\begin{array}{l}1871 \\
1881 \\
1891 \\
1901\end{array}$ & $\begin{array}{c}\overline{-} \\
0.000 \\
0.040 \\
0.000 \\
0.041 \\
0.000 \\
0.048\end{array}$ & $\begin{array}{c}\overline{-} \\
0 \cdot 000 \\
0 \cdot 127 \\
0 \cdot 000 \\
0 \cdot 129 \\
0 \cdot 000 \\
0 \cdot 131\end{array}$ & $\begin{array}{l}0.001 \\
0.259 \\
0.001 \\
0.273 \\
0.001 \\
0.275 \\
0.001 \\
0.269\end{array}$ & $\begin{array}{l}0.001 \\
0.457 \\
0.002 \\
0.460 \\
0.003 \\
0.460 \\
0.002 \\
0.463\end{array}$ & $\begin{array}{l}0.004 \\
0.601 \\
0.005 \\
0.652 \\
0.006 \\
0.620 \\
0.004 \\
0.580\end{array}$ & $\begin{array}{c}0.006 \\
0.778 \\
0.005 \\
0.802 \\
0.007 \\
0.745 \\
=\end{array}$ & $\begin{array}{c}0.012 \\
0.988 \\
0.008 \\
0.926 \\
0.011 \\
0.870 \\
=\end{array}$ & $\begin{array}{c}0.013 \\
1 \cdot 103 \\
0.016 \\
1.064 \\
= \\
=\end{array}$ & $\begin{array}{c}0.023 \\
1 \cdot 271 \\
0.019 \\
1.275 \\
= \\
= \\
=\end{array}$ & $\begin{array}{c}0.027 \\
1.745 \\
= \\
= \\
=\end{array}$ & $\begin{array}{l}0.029 \\
2.101 \\
= \\
= \\
=\end{array}$ \\
\hline 23 & $\begin{array}{l}\text { Cancer of Ovaries and } \\
\text { Fallopian Tubes }\end{array}$ & $\begin{array}{l}1871 \\
1881 \\
1891 \\
1901\end{array}$ & $\begin{array}{l}0 . \overline{012} \\
0.015 \\
0.018 \\
*\end{array}$ & $\begin{array}{l}0 . \overline{021} \\
0.033 \\
0.043\end{array}$ & $\begin{array}{l}0.046 \\
0 \cdot 050 \\
0.072 \\
0.086\end{array}$ & $\begin{array}{l}0.065 \\
0 \cdot 109 \\
0 \cdot 133 \\
0 \cdot 158\end{array}$ & $\begin{array}{l}0.125 \\
0.166 \\
0.201 \\
0.248\end{array}$ & $\begin{array}{l}0 \cdot 161 \\
0 \cdot 221 \\
0 \cdot 266 \\
-\end{array}$ & $\begin{array}{l}0.210 \\
0 \cdot 254 \\
0.291 \\
-\end{array}$ & $\begin{array}{l}0 \cdot 258 \\
0 \cdot 296 \\
=\end{array}$ & $\begin{array}{c}0 \cdot 270 \\
0 \cdot 311 \\
=\end{array}$ & $\begin{array}{l}0 \cdot 293 \\
=\end{array}$ & $\begin{array}{l}0.296 \\
=\end{array}$ \\
\hline 24 & $\begin{array}{l}\text { Cancer of Vulva and } \\
\text { Vagina }\end{array}$ & $\begin{array}{l}1871 \\
1881 \\
1891 \\
1901\end{array}$ & $\begin{array}{l}0 . \overline{002} \\
0.002 \\
0.001\end{array}$ & $\begin{array}{l}0.005 \\
0.005 \\
0.004\end{array}$ & $\begin{array}{l}0.008 \\
0.007 \\
0.006 \\
0.007\end{array}$ & $\begin{array}{l}0.017 \\
0.013 \\
0.011 \\
0.009\end{array}$ & $\begin{array}{l}0.024 \\
0.023 \\
0.020 \\
0.014\end{array}$ & $\begin{array}{l}0.040 \\
0.034 \\
0.022 \\
-\end{array}$ & $\begin{array}{l}0.059 \\
0.052 \\
0.036 \\
-\end{array}$ & $\begin{array}{c}0.087 \\
0.067 \\
=\end{array}$ & $\begin{array}{l}0.126 \\
0.099 \\
=\end{array}$ & $\begin{array}{l}0.138 \\
=\end{array}$ & $\begin{array}{l}0.177 \\
=\end{array}$ \\
\hline
\end{tabular}


APPENDIX TABLE I (contin.)

\begin{tabular}{|c|c|c|c|c|c|c|c|c|c|c|c|c|c|}
\hline \multirow{2}{*}{$\begin{array}{l}\text { Fig. } \\
\text { No. }\end{array}$} & \multirow{2}{*}{ Cause of Death } & \multirow{2}{*}{$\begin{array}{c}\text { Cohort } \\
\text { born }\end{array}$} & \multicolumn{11}{|c|}{ Age } \\
\hline & & & 30 & 35 & 40 & $45-$ & 50 & 55- & 60 & 65 & 70 & 75 & $80-84$ \\
\hline 25 & $\begin{array}{l}\text { Cancer of Uterus (Corpus } \\
\text { and Cervix) } \\
\text { (C) }\end{array}$ & $\begin{array}{l}1871 \\
1881 \\
1891 \\
1901\end{array}$ & $\begin{array}{l}0 . \overline{052} \\
0.054 \\
0.044\end{array}$ & $\begin{array}{l}0 . \overline{146} \\
0 \cdot 145 \\
0.098\end{array}$ & $\begin{array}{l}0 \cdot 321 \\
0 \cdot 270 \\
0 \cdot 233 \\
0 \cdot 170\end{array}$ & $\begin{array}{l}0.477 \\
0.396 \\
0.342 \\
0.242\end{array}$ & $\begin{array}{l}0.609 \\
0.480 \\
0.430 \\
0.303\end{array}$ & $\begin{array}{c}0.619 \\
0.538 \\
0.484 \\
-\end{array}$ & $\begin{array}{c}0.642 \\
0.597 \\
0.488 \\
-\end{array}$ & $\begin{array}{c}0.688 \\
0.614 \\
=\end{array}$ & $\begin{array}{c}0.753 \\
0.578 \\
=\end{array}$ & $\begin{array}{c}0.748 \\
= \\
=\end{array}$ & $\begin{array}{l}0.724 \\
= \\
-\end{array}$ \\
\hline 26 & Cancer of Testes & $\begin{array}{l}1871 \\
1881 \\
1891 \\
1901\end{array}$ & $\begin{array}{l}0 . \overline{008} \\
0.010 \\
0.011\end{array}$ & $\begin{array}{l}0 . \overline{009} \\
0.012 \\
0.015\end{array}$ & $\begin{array}{l}0.008 \\
0.010 \\
0.014 \\
0.011\end{array}$ & $\begin{array}{l}0.009 \\
0.009 \\
0.009 \\
0.012\end{array}$ & $\begin{array}{l}0.005 \\
0.012 \\
0.010 \\
0.008\end{array}$ & $\begin{array}{c}0.006 \\
0.009 \\
0.009 \\
-\end{array}$ & $\begin{array}{c}0.009 \\
0.010 \\
0.011 \\
-\end{array}$ & $\begin{array}{c}0.017 \\
0.011 \\
=\end{array}$ & $\begin{array}{c}0.020 \\
0.014 \\
= \\
-\end{array}$ & $\begin{array}{c}0.019 \\
= \\
=\end{array}$ & $\begin{array}{l}0.020 \\
\text { 二 }\end{array}$ \\
\hline 27 & $\begin{array}{l}\text { Cancer of Penis and } \\
\text { Scrotum }\end{array}$ & $\begin{array}{l}1871 \\
1881 \\
1891 \\
1901\end{array}$ & $\begin{array}{l}0 . \overline{002} \\
0.001 \\
0.001\end{array}$ & $\begin{array}{l}0 . \overline{003} \\
0.002 \\
0.002\end{array}$ & $\begin{array}{l}0.007 \\
0.007 \\
0.004 \\
0.003\end{array}$ & $\begin{array}{l}0.011 \\
0.010 \\
0.005 \\
0.005\end{array}$ & $\begin{array}{l}0.021 \\
0.016 \\
0.010 \\
0.006\end{array}$ & $\begin{array}{c}0.028 \\
0.018 \\
0.010 \\
-\end{array}$ & $\begin{array}{c}0.044 \\
0.033 \\
0.017 \\
-\end{array}$ & $\begin{array}{c}0.055 \\
0.026 \\
= \\
-\end{array}$ & $\begin{array}{c}0.080 \\
0.041 \\
=\end{array}$ & $\begin{array}{c}0.086 \\
= \\
=\end{array}$ & $\begin{array}{c}0.094 \\
=\end{array}$ \\
\hline 28 & $\begin{array}{c}\text { Cancer of Prostate } \\
\text { (C) }\end{array}$ & $\begin{array}{l}1871 \\
1881 \\
1891 \\
1901\end{array}$ & $\begin{array}{l}0 . \overline{001} \\
0.001 \\
0.001\end{array}$ & $\begin{array}{l}0 . \overline{001} \\
0.002 \\
0.002\end{array}$ & $\begin{array}{l}0.002 \\
0.003 \\
0.003 \\
0.004\end{array}$ & $\begin{array}{l}0.008 \\
0.010 \\
0.011 \\
0.013\end{array}$ & $\begin{array}{l}0.035 \\
0.042 \\
0.039 \\
0.033\end{array}$ & $\begin{array}{c}0.099 \\
0.117 \\
0.120 \\
-\end{array}$ & $\begin{array}{c}0.278 \\
0.296 \\
0.248 \\
-\end{array}$ & $\begin{array}{c}0.616 \\
0.657 \\
=\end{array}$ & $\begin{array}{c}1 \cdot 142 \\
1 \cdot 304 \\
=\end{array}$ & $\begin{array}{c}1.963 \\
=\end{array}$ & $\begin{array}{c}2 \cdot 830 \\
= \\
=\end{array}$ \\
\hline 29 & $\begin{array}{l}\text { Cancer at All Other Sites } \\
\text { (C) }\end{array}$ & $\begin{array}{l}1871 \\
1881 \\
1891 \\
1901\end{array}$ & $\begin{array}{c}- \\
0.028 \\
0.028 \\
0.023 \\
0.021 \\
0.021 \\
0.020 \\
\end{array}$ & $\begin{array}{c}\bar{z} \\
0.033 \\
0.029 \\
0.038 \\
0.029 \\
0.044 \\
0.022\end{array}$ & $\begin{array}{l}0.083 \\
0.064 \\
0.061 \\
0.051 \\
0.061 \\
0.047 \\
0.053 \\
0.045\end{array}$ & $\begin{array}{l}0.117 \\
0.090 \\
0.098 \\
0.070 \\
0.095 \\
0.075 \\
0.100 \\
0.087\end{array}$ & $\begin{array}{l}0.184 \\
0.125 \\
0.168 \\
0.127 \\
0.134 \\
0.098 \\
0.171 \\
0.131\end{array}$ & $\begin{array}{l}0.226 \\
0.141 \\
0.219 \\
0.155 \\
0.222 \\
0.146 \\
=\end{array}$ & $\begin{array}{c}0.362 \\
0.262 \\
0.292 \\
0.166 \\
0.376 \\
0.277 \\
= \\
=\end{array}$ & $\begin{array}{c}0.447 \\
0.306 \\
0.418 \\
0.260 \\
= \\
=\end{array}$ & $\begin{array}{c}0.552 \\
0.331 \\
0.514 \\
0.495 \\
= \\
=\end{array}$ & $\begin{array}{l}0.665 \\
0.341 \\
= \\
= \\
=\end{array}$ & $\begin{array}{c}0.954 \\
0.781 \\
= \\
= \\
= \\
=\end{array}$ \\
\hline 30 & $\begin{array}{l}\text { Benign Tumours and } \\
\text { Tumours of Undeter- } \\
\text { mined Nature }\end{array}$ & $\begin{array}{l}1871 \\
1881 \\
1891 \\
1901\end{array}$ & $\begin{array}{c}\overline{ } \\
\overline{0.026} \\
0.042 \\
0.033 \\
0.043 \\
0.033 \\
0.046\end{array}$ & $\begin{array}{c}\overline{-} \\
0.038 \\
0.072 \\
0.051 \\
0.077 \\
0.044 \\
0.069\end{array}$ & $\begin{array}{l}0.041 \\
0.096 \\
0.060 \\
0.122 \\
0.069 \\
0.110 \\
0.053 \\
0.098\end{array}$ & $\begin{array}{l}0.057 \\
0.132 \\
0.085 \\
0.165 \\
0.076 \\
0.121 \\
0.077 \\
0.089\end{array}$ & $\begin{array}{l}0.096 \\
0.147 \\
0.111 \\
0.150 \\
0.102 \\
0.117 \\
0.120 \\
0.057\end{array}$ & $\begin{array}{c}0 \cdot 128 \\
0 \cdot 167 \\
0 \cdot 115 \\
0 \cdot 109 \\
0 \cdot 127 \\
0 \cdot 097 \\
=\end{array}$ & $\begin{array}{l}0.150 \\
0.147 \\
0.130 \\
0.104 \\
0.136 \\
0.086 \\
=\end{array}$ & $\begin{array}{c}0.174 \\
0.083 \\
0.105 \\
0.095 \\
= \\
=\end{array}$ & $\begin{array}{c}0.128 \\
0.122 \\
0.126 \\
0.142 \\
= \\
=\end{array}$ & $\begin{array}{c}0.132 \\
0.136 \\
= \\
= \\
= \\
=\end{array}$ & $\begin{array}{c}0.194 \\
0.155 \\
= \\
= \\
=\end{array}$ \\
\hline 31 & $\begin{array}{l}\text { Leukaemia (All Types) } \\
\text { (C) }\end{array}$ & $\begin{array}{l}1871 \\
1881 \\
1891 \\
1901\end{array}$ & $\begin{array}{l}\overline{7} \\
0.009 \\
0.008 \\
0.009 \\
0.009 \\
0.014 \\
0.011\end{array}$ & $\begin{array}{c}\overline{-} \\
0.009 \\
0.011 \\
0.012 \\
0.013 \\
0.019 \\
0.017\end{array}$ & $\begin{array}{l}0.012 \\
0.017 \\
0.014 \\
0.011 \\
0.019 \\
0.016 \\
0.022 \\
0.021\end{array}$ & $\begin{array}{l}0.017 \\
0.014 \\
0.021 \\
0.019 \\
0.027 \\
0.025 \\
0.043 \\
0.035\end{array}$ & $\begin{array}{l}0.020 \\
0.021 \\
0.027 \\
0.026 \\
0.041 \\
0.034 \\
0.054 \\
0.050\end{array}$ & $\begin{array}{c}0.031 \\
0.025 \\
0.049 \\
0.040 \\
0.075 \\
0.059 \\
=\end{array}$ & $\begin{array}{l}0.042 \\
0.039 \\
0.080 \\
0.061 \\
0.132 \\
0.098 \\
=\end{array}$ & $\begin{array}{l}0.079 \\
0.0557 \\
0.112 \\
0.087 \\
= \\
=\end{array}$ & $\begin{array}{l}0.074 \\
0.059 \\
0.170 \\
0.137 \\
= \\
=\end{array}$ & $\begin{array}{l}0.142 \\
0.078 \\
= \\
= \\
=\end{array}$ & $\begin{array}{c}0.187 \\
0.130 \\
= \\
= \\
=\end{array}$ \\
\hline 32 & $\begin{array}{l}\text { Hodgkin's Disease } \\
\text { (C) }\end{array}$ & $\begin{array}{l}1871 \\
1881 \\
1891 \\
1901\end{array}$ & $\begin{array}{c}\overline{7} \\
0.007 \\
0.005 \\
0.011 \\
0.007 \\
0.017 \\
0.011\end{array}$ & $\begin{array}{c}\overline{-} \\
0.011 \\
0.005 \\
0.016 \\
0.008 \\
0.017 \\
0.013\end{array}$ & $\begin{array}{l}0.009 \\
0.005 \\
0.013 \\
0.005 \\
0.018 \\
0.010 \\
0.020 \\
0.008\end{array}$ & $\begin{array}{l}0.013 \\
0.006 \\
0.016 \\
0.007 \\
0.019 \\
0.010 \\
0.027 \\
0.013\end{array}$ & $\begin{array}{l}0.020 \\
0.011 \\
0.027 \\
0.012 \\
0.026 \\
0.016 \\
0.035 \\
0.014\end{array}$ & $\begin{array}{l}0.028 \\
0.015 \\
0.030 \\
0.015 \\
0.039 \\
0.016 \\
=\end{array}$ & $\begin{array}{c}0.033 \\
0.019 \\
0.040 \\
0.020 \\
0.046 \\
0.027 \\
= \\
-\end{array}$ & $\begin{array}{l}0.036 \\
0.023 \\
0.042 \\
0.023 \\
= \\
=\end{array}$ & $\begin{array}{l}0.038 \\
0.016 \\
0.047 \\
0.025 \\
= \\
=\end{array}$ & $\begin{array}{c}0.044 \\
0.024 \\
= \\
= \\
=\end{array}$ & $\begin{array}{c}0.031 \\
0.026 \\
= \\
= \\
=\end{array}$ \\
\hline
\end{tabular}


APPENDIX TABLE II

PROPORTIONATE CHANGES IN DEATH RATES AT AGES 50-54, 60-64, AND 70-74. THESE ARE THE AGES ATTAINED BY THE 1901, 1891, AND 1881 COHORTS RESPECTIVELY IN THE QUINQUENNIUM 1951-55

The death rates at each of these ages are expressed as a percentage of the death rates of the 1871 cohort at these ages.

\begin{tabular}{|c|c|c|c|c|c|c|c|c|}
\hline \multirow{2}{*}{$\begin{array}{l}\text { Fig- } \\
\text { ure } \\
\text { No. }\end{array}$} & \multirow[t]{2}{*}{$\begin{array}{c}\text { Cause of } \\
\text { Death }\end{array}$} & \multirow{2}{*}{$\begin{array}{l}\text { Co- } \\
\text { hort } \\
\text { Born }\end{array}$} & \multicolumn{3}{|c|}{$\begin{array}{c}\text { Males } \\
\text { Age }\end{array}$} & \multicolumn{3}{|c|}{ Females } \\
\hline & & & $70-$ & $60-$ & 50- & 70 & $60-$ & 50- \\
\hline 2 & All & $\begin{array}{l}1881 \\
1891 \\
1901\end{array}$ & $\begin{array}{c}106 \cdot 0 \\
二\end{array}$ & $\begin{array}{l}98 \cdot 1 \\
99 \cdot 2 \\
-\end{array}$ & $\begin{array}{l}98 \cdot 0 \\
88 \cdot 3 \\
78 \cdot 6\end{array}$ & $\underline{92 \cdot 3}$ & $\begin{array}{l}81 \cdot 6 \\
71 \cdot 3 \\
-\end{array}$ & $\begin{array}{l}90.4 \\
73.4 \\
58.5\end{array}$ \\
\hline- & $\begin{array}{l}\text { All Neo- } \\
\text { plasms }\end{array}$ & $\begin{array}{l}1881 \\
1891 \\
1901\end{array}$ & $\begin{array}{c}107 \cdot 1 \\
-\end{array}$ & $\begin{array}{r}99.5 \\
113.5 \\
-\end{array}$ & $\begin{array}{r}97 \cdot 5 \\
101 \cdot 5 \\
124 \cdot 2\end{array}$ & $\begin{array}{l}93 \cdot 7 \\
=\end{array}$ & $\begin{array}{l}92 \cdot 7 \\
85 \cdot 7 \\
-\end{array}$ & $\begin{array}{l}94 \cdot 7 \\
89 \cdot 8 \\
81 \cdot 0\end{array}$ \\
\hline 3 & $\begin{array}{l}\text { Cancer at } \\
\text { All Sites }\end{array}$ & $\begin{array}{l}1881 \\
1891 \\
1901\end{array}$ & $\begin{array}{c}106 \cdot 3 \\
-\end{array}$ & $\begin{array}{r}99 \cdot 1 \\
112 \cdot 5 \\
-\end{array}$ & $\begin{array}{r}96 \cdot 0 \\
100 \cdot 1 \\
122 \cdot 4\end{array}$ & $\begin{array}{l}92 \cdot 2 \\
=\end{array}$ & $\begin{array}{l}92.9 \\
85.0 \\
-\end{array}$ & $\begin{array}{l}94.0 \\
89.6 \\
81.9\end{array}$ \\
\hline 4 & $\begin{array}{l}\text { Cancer at } \\
\text { All Sites } \\
\text { except } \\
\text { Lungs }\end{array}$ & $\begin{array}{l}1881 \\
1891 \\
1901\end{array}$ & $\begin{array}{l}92 \cdot 8 \\
二\end{array}$ & $\begin{array}{l}87 \cdot 0 \\
75 \cdot 2 \\
-\end{array}$ & $\begin{array}{l}87 \cdot 0 \\
74 \cdot 9 \\
68 \cdot 4\end{array}$ & $\begin{array}{l}90 \cdot 0 \\
=\end{array}$ & $\begin{array}{l}91 \cdot 5 \\
81 \cdot 1 \\
-\end{array}$ & $\begin{array}{l}92 \cdot 8 \\
86 \cdot 9 \\
77 \cdot 6\end{array}$ \\
\hline 5 & $\begin{array}{l}\text { Cancer of } \\
\text { Lungs }\end{array}$ & $\begin{array}{l}1881 \\
1891 \\
1901\end{array}$ & $\begin{array}{c}331 \cdot 7 \\
-\end{array}$ & $\begin{array}{c}286 \cdot 4 \\
689 \cdot 2 \\
-\end{array}$ & $\begin{array}{r}387 \cdot 9 \\
913 \cdot 6 \\
1865 \cdot 1\end{array}$ & $\begin{array}{c}166 \cdot 7 \\
=\end{array}$ & $\begin{array}{c}147 \cdot 5 \\
241 \cdot 5 \\
-\end{array}$ & $\begin{array}{l}211 \cdot 5 \\
361 \cdot 5 \\
519 \cdot 2\end{array}$ \\
\hline 6 & $\begin{array}{l}\text { Cancer of } \\
\text { Stomach }\end{array}$ & $\begin{array}{l}1881 \\
1891 \\
1901\end{array}$ & $\begin{array}{c}101 \cdot 1 \\
-\end{array}$ & $\begin{array}{l}96 \cdot 8 \\
94 \cdot 1 \\
-\end{array}$ & $\begin{array}{r}105 \cdot 6 \\
100 \cdot 2 \\
92 \cdot 8\end{array}$ & $\begin{array}{l}85 \cdot 6 \\
=\end{array}$ & $\begin{array}{l}87 \cdot 1 \\
63 \cdot 7 \\
-\end{array}$ & $\begin{array}{l}91 \cdot 5 \\
74 \cdot 3 \\
60 \cdot 2\end{array}$ \\
\hline 7 & $\begin{array}{l}\text { Cancer of } \\
\text { Intestines }\end{array}$ & $\begin{array}{l}1881 \\
1891 \\
1901\end{array}$ & $\begin{array}{l}81 \cdot 5 \\
-\end{array}$ & $\begin{array}{c}106 \cdot 3 \\
72 \cdot 1 \\
-\end{array}$ & $\begin{array}{l}99 \cdot 5 \\
98 \cdot 5 \\
79 \cdot 4\end{array}$ & $\begin{array}{l}74 \cdot 6 \\
-\end{array}$ & $\begin{array}{c}102 \cdot 2 \\
78 \cdot 9 \\
-\end{array}$ & $\begin{array}{l}88.9 \\
92.9 \\
73.8\end{array}$ \\
\hline 8 & $\begin{array}{l}\text { Cancer of } \\
\text { Rectum }\end{array}$ & $\begin{array}{l}1881 \\
1891 \\
1901\end{array}$ & $\begin{array}{l}77 \cdot 3 \\
-\end{array}$ & $\begin{array}{l}91 \cdot 8 \\
63 \cdot 0 \\
-\end{array}$ & $\begin{array}{l}93 \cdot 5 \\
81 \cdot 3 \\
62 \cdot 5\end{array}$ & $\begin{array}{l}80.4 \\
-\end{array}$ & $\begin{array}{l}93 \cdot 0 \\
77 \cdot 6 \\
-\end{array}$ & $\begin{array}{l}81 \cdot 5 \\
90.4 \\
74 \cdot 1\end{array}$ \\
\hline 9 & $\begin{array}{l}\text { Cancer of } \\
\text { Liver and } \\
\text { Gall- } \\
\text { Bladder }\end{array}$ & $\begin{array}{l}1881 \\
1891 \\
1901\end{array}$ & $\begin{array}{l}71 \cdot 9 \\
-\end{array}$ & $\begin{array}{l}72 \cdot 1 \\
54 \cdot 5 \\
-\end{array}$ & $\begin{array}{l}59 \cdot 2 \\
47 \cdot 4 \\
36 \cdot 2\end{array}$ & $\frac{63 \cdot 4}{二}$ & $\begin{array}{l}67 \cdot 6 \\
45 \cdot 5 \\
-\end{array}$ & $\begin{array}{l}57 \cdot 3 \\
42 \cdot 1 \\
30 \cdot 5\end{array}$ \\
\hline 10 & $\begin{array}{l}\text { Cancer of } \\
\text { Pancreas }\end{array}$ & $\begin{array}{l}1881 \\
1891 \\
1901\end{array}$ & $\begin{array}{c}133 \cdot 5 \\
-\end{array}$ & $\begin{array}{c}108 \cdot 6 \\
141 \cdot 1 \\
-\end{array}$ & $\begin{array}{l}142 \cdot 4 \\
147.5 \\
154 \cdot 2\end{array}$ & $\begin{array}{c}119 \cdot 3 \\
-\end{array}$ & $\begin{array}{l}95 \cdot 8 \\
98 \cdot 6 \\
-\end{array}$ & $\begin{array}{l}118 \cdot 6 \\
116 \cdot 3 \\
125 \cdot 6\end{array}$ \\
\hline 11 & $\begin{array}{l}\text { Cancer of } \\
\text { Tongue }\end{array}$ & $\begin{array}{l}1881 \\
1891 \\
1901\end{array}$ & $\begin{array}{l}48 \cdot 1 \\
-\end{array}$ & $\begin{array}{l}47 \cdot 6 \\
17 \cdot 1 \\
-\end{array}$ & $\begin{array}{r}43 \cdot 7 \\
16 \cdot 2 \\
6 \cdot 3\end{array}$ & $\begin{array}{l}89 \cdot 7 \\
=\end{array}$ & $\begin{array}{c}73.9 \\
60.9 \\
-\end{array}$ & $\begin{array}{r}100 \cdot 0 \\
112 \cdot 5 \\
75 \cdot 0\end{array}$ \\
\hline 12 & $\begin{array}{l}\text { Cancer of } \\
\text { Mouth } \\
\text { and Tonsils }\end{array}$ & $\begin{array}{l}1881 \\
1891 \\
1901\end{array}$ & $\begin{array}{l}89 \cdot 9 \\
-\end{array}$ & $\begin{array}{l}44 \cdot 1 \\
27 \cdot 6 \\
-\end{array}$ & $\begin{array}{l}43 \cdot 6 \\
16 \cdot 7 \\
17 \cdot 9\end{array}$ & $\begin{array}{c}126 \cdot 3 \\
-\end{array}$ & $\begin{array}{c}69 \cdot 2 \\
100 \cdot 0 \\
-\end{array}$ & $\begin{array}{l}87 \cdot 5 \\
37 \cdot 5 \\
62 \cdot 5\end{array}$ \\
\hline 13 & $\begin{array}{l}\text { Cancer of } \\
\text { Pharynx }\end{array}$ & $\begin{array}{l}1881 \\
1891 \\
1901\end{array}$ & $\begin{array}{l}90 \cdot 5 \\
=\end{array}$ & $\begin{array}{l}65 \cdot 3 \\
51 \cdot 6 \\
-\end{array}$ & $\begin{array}{l}87 \cdot 5 \\
56 \cdot 3 \\
50 \cdot 0\end{array}$ & $\begin{array}{c}187 \cdot 0 \\
=\end{array}$ & $\begin{array}{c}81 \cdot 3 \\
187 \cdot 5 \\
-\end{array}$ & $\begin{array}{r}83 \cdot 3 \\
83 \cdot 3 \\
158 \cdot 3\end{array}$ \\
\hline 14 & $\begin{array}{l}\text { Cancer of } \\
\text { Larynx }\end{array}$ & $\begin{array}{l}1881 \\
1891 \\
1901\end{array}$ & $\begin{array}{l}70 \cdot 7 \\
-\end{array}$ & $\begin{array}{l}71 \cdot 2 \\
50.7 \\
-\end{array}$ & $\begin{array}{l}75 \cdot 3 \\
44 \cdot 3 \\
37 \cdot 1\end{array}$ & ב5.0 & $\begin{array}{c}105 \cdot 4 \\
62 \cdot 2 \\
-\end{array}$ & $\begin{array}{r}111.5 \\
103.9 \\
50.0\end{array}$ \\
\hline 15 & $\begin{array}{l}\text { Cancer of } \\
\text { Oeso- } \\
\text { phagus }\end{array}$ & $\begin{array}{l}1881 \\
1891 \\
1901 \\
\end{array}$ & = & $\begin{array}{l}56 \cdot 9 \\
40 \cdot 5 \\
-\end{array}$ & $\begin{array}{l}54 \cdot 3 \\
31 \cdot 5 \\
27 \cdot 4\end{array}$ & $\begin{array}{c}116 \cdot 7 \\
-\end{array}$ & $\begin{array}{l}86 \cdot 8 \\
74 \cdot 6 \\
-\end{array}$ & $\begin{array}{l}88 \cdot 7 \\
61 \cdot 3 \\
51 \cdot 6\end{array}$ \\
\hline 16 & $\begin{array}{l}\text { Cancer of } \\
\text { Kidneys } \\
\text { and } \\
\text { Adrenals }\end{array}$ & $\begin{array}{l}1881 \\
1891 \\
1901\end{array}$ & $\begin{array}{c}181 \cdot 5 \\
=\end{array}$ & $\begin{array}{c}100.0 \\
153.4 \\
-\end{array}$ & $\begin{array}{l}129.6 \\
140.7 \\
200.0\end{array}$ & $\begin{array}{c}144 \cdot 1 \\
=\end{array}$ & $\begin{array}{r}86 \cdot 7 \\
106 \cdot 7 \\
-\end{array}$ & $\begin{array}{l}133 \cdot 3 \\
111 \cdot 1 \\
116 \cdot 7\end{array}$ \\
\hline 17 & $\begin{array}{l}\text { Cancer of } \\
\text { Urinary } \\
\text { Bladder }\end{array}$ & $\begin{array}{l}1881 \\
1891 \\
1901\end{array}$ & $\begin{array}{c}132 \cdot 3 \\
=\end{array}$ & $\begin{array}{c}120 \cdot 2 \\
148 \cdot 6 \\
-\end{array}$ & $\begin{array}{l}129 \cdot 2 \\
164 \cdot 6 \\
183 \cdot 3\end{array}$ & $\begin{array}{c}100 \cdot 6 \\
=\end{array}$ & $\begin{array}{c}139 \cdot 0 \\
108 \cdot 5 \\
-\end{array}$ & $\begin{array}{r}81 \cdot 8 \\
127 \cdot 3 \\
113 \cdot 6\end{array}$ \\
\hline
\end{tabular}

\begin{tabular}{|c|c|c|c|c|c|c|c|c|}
\hline \multirow{2}{*}{$\begin{array}{l}\text { Fig- } \\
\text { ure } \\
\text { No. }\end{array}$} & \multirow[t]{2}{*}{$\begin{array}{l}\text { Cause of } \\
\text { Death }\end{array}$} & \multirow{2}{*}{$\begin{array}{l}\text { Co- } \\
\text { hort } \\
\text { Born }\end{array}$} & \multicolumn{3}{|c|}{$\begin{array}{c}\text { Males } \\
\text { Age }\end{array}$} & \multicolumn{3}{|c|}{$\begin{array}{c}\text { Females } \\
\text { Age }\end{array}$} \\
\hline & & & 70 & 60 & 50 & 70 & 60 & 50 \\
\hline 18 & $\begin{array}{c}\text { Cancer of } \\
\text { Skin (ex- } \\
\text { cluding } \\
\text { Scrotum) }\end{array}$ & $\begin{array}{l}1881 \\
1891 \\
1901\end{array}$ & $\begin{array}{l}61 \cdot 6 \\
二\end{array}$ & $\begin{array}{l}84 \cdot 0 \\
61 \cdot 3 \\
-\end{array}$ & $\begin{array}{l}86 \cdot 7 \\
66 \cdot 7 \\
66 \cdot 7\end{array}$ & $\begin{array}{l}80 \cdot 0 \\
=\end{array}$ & $\begin{array}{l}76 \cdot 2 \\
69.1 \\
-\end{array}$ & $\begin{array}{l}81 \cdot 8 \\
72.7 \\
54 \cdot 5\end{array}$ \\
\hline 19 & $\begin{array}{l}\text { Cancer of } \\
\text { Lips }\end{array}$ & $\begin{array}{l}1881 \\
1891 \\
1901\end{array}$ & ב1.6 & $\begin{array}{l}52 \cdot 5 \\
22 \cdot 5 \\
-\end{array}$ & $\begin{array}{r}83 \cdot 3 \\
33 \cdot 3 \\
8 \cdot 3\end{array}$ & $\begin{array}{c}100 \cdot 0 \\
=\end{array}$ & $\begin{array}{c}100 \cdot 0 \\
50 \cdot 0 \\
-\end{array}$ & $\begin{array}{r}100 \cdot 0 \\
0.0 \\
0.0\end{array}$ \\
\hline 20 & $\begin{array}{l}\text { Cancer of } \\
\text { Bones } \\
\text { (exclud- } \\
\text { ing Jaw) }\end{array}$ & \begin{tabular}{|l|}
1881 \\
1891 \\
1901
\end{tabular} & $\frac{74 \cdot 5}{=}$ & $\begin{array}{c}128 \cdot 6 \\
87 \cdot 3 \\
-\end{array}$ & $\begin{array}{r}134 \cdot 5 \\
141 \cdot 4 \\
86 \cdot 2\end{array}$ & $\begin{array}{l}67 \cdot 7 \\
二\end{array}$ & $\begin{array}{c}106 \cdot 7 \\
75 \cdot 6 \\
-\end{array}$ & $\begin{array}{r}103 \cdot 6 \\
100 \cdot 0 \\
53 \cdot 6\end{array}$ \\
\hline 21 & $\begin{array}{l}\text { Cancer of } \\
\text { Jaw }\end{array}$ & $\begin{array}{l}1881 \\
1891 \\
1901\end{array}$ & 三 & $\begin{array}{c}49 \cdot 4 \\
9 \cdot 9 \\
-\end{array}$ & $\begin{array}{r}52 \cdot 8 \\
22 \cdot 6 \\
7 \cdot 5\end{array}$ & $\begin{array}{l}48 \cdot 2 \\
=\end{array}$ & $\begin{array}{l}31 \cdot 4 \\
17 \cdot 1 \\
-\end{array}$ & $\begin{array}{l}88 \cdot 2 \\
41 \cdot 2 \\
17 \cdot 7\end{array}$ \\
\hline 22 & $\begin{array}{l}\text { Cancer of } \\
\text { Breast }\end{array}$ & $\begin{array}{l}1881 \\
1891 \\
1901\end{array}$ & $\begin{array}{l}82 \cdot 6 \\
=\end{array}$ & $\begin{array}{l}66 \cdot 7 \\
91 \cdot 7 \\
-\end{array}$ & $\begin{array}{l}125.0 \\
150 \cdot 0 \\
100 \cdot 0\end{array}$ & $\begin{array}{c}100 \cdot 3 \\
-\end{array}$ & $\begin{array}{l}93: 7 \\
88 \cdot 1 \\
-\end{array}$ & $\begin{array}{r}108 \cdot 5 \\
103 \cdot 2 \\
96 \cdot 5\end{array}$ \\
\hline 23 & $\begin{array}{l}\text { Cancer of } \\
\text { Ovaries } \\
\text { and Fall- } \\
\text { opian } \\
\text { Tubes }\end{array}$ & \begin{tabular}{|l|}
1881 \\
1891 \\
1901
\end{tabular} & $=$ & 二 & 二 & $\begin{array}{c}115 \cdot 2 \\
-\end{array}$ & $\begin{array}{c}121 \cdot 0 \\
138 \cdot 6 \\
-\end{array}$ & $\begin{array}{l}132 \cdot 8 \\
160 \cdot 8 \\
198 \cdot 4\end{array}$ \\
\hline 24 & $\begin{array}{l}\text { Cancer of } \\
\text { Vulva } \\
\text { and } \\
\text { Vagina }\end{array}$ & \begin{tabular}{|l|}
1881 \\
1891 \\
1901
\end{tabular} & 二 & 二 & 二 & $\begin{array}{l}78 \cdot 6 \\
=\end{array}$ & $\begin{array}{l}88 \cdot 1 \\
61 \cdot 0 \\
-\end{array}$ & $\begin{array}{l}95 \cdot 8 \\
83 \cdot 3 \\
58 \cdot 3\end{array}$ \\
\hline 25 & $\begin{array}{l}\text { Cancer of } \\
\text { Uterus } \\
\text { (Corpus } \\
\text { and } \\
\text { Cervix) }\end{array}$ & $\begin{array}{l}1881 \\
1891 \\
1901\end{array}$ & 二 & 三 & $\bar{z}$ & $\begin{array}{l}76 \cdot 8 \\
=\end{array}$ & $\begin{array}{l}93.0 \\
76.0 \\
-\end{array}$ & $\begin{array}{l}78.8 \\
70.6 \\
49.8\end{array}$ \\
\hline 26 & $\begin{array}{l}\text { Cancer of } \\
\text { Testes }\end{array}$ & $\begin{array}{l}1881 \\
1891 \\
1901\end{array}$ & $\begin{array}{l}70 \cdot 0 \\
=\end{array}$ & $\begin{array}{c}111 \cdot 1 \\
122 \cdot 2 \\
-\end{array}$ & $\begin{array}{l}240.0 \\
200 \cdot 0 \\
160 \cdot 0\end{array}$ & $=$ & 二 & $=$ \\
\hline 27 & $\begin{array}{l}\text { Cancer of } \\
\text { Penis and } \\
\text { Scrotum }\end{array}$ & $\begin{array}{l}1881 \\
1891 \\
1901\end{array}$ & $\begin{array}{l}51 \cdot 3 \\
=\end{array}$ & $\begin{array}{l}75.0 \\
38.6 \\
-\end{array}$ & $\begin{array}{l}76 \cdot 2 \\
47 \cdot 6 \\
28 \cdot 6\end{array}$ & $\overline{-}$ & $\bar{z}$ & $=$ \\
\hline 28 & $\begin{array}{l}\text { Cancer of } \\
\text { Prostate }\end{array}$ & $\begin{array}{l}1881 \\
1891 \\
1901\end{array}$ & $\begin{array}{c}114 \cdot 2 \\
-\end{array}$ & $\begin{array}{c}106 \cdot 5 \\
89 \cdot 2 \\
-\end{array}$ & $\begin{array}{r}120.0 \\
111.4 \\
94.3\end{array}$ & 二 & 二 & 二 \\
\hline 29 & $\begin{array}{l}\text { Cancer of } \\
\text { All Other } \\
\text { Sites }\end{array}$ & $\begin{array}{l}1881 \\
1891 \\
1901\end{array}$ & $\begin{array}{l}92 \cdot 3 \\
=\end{array}$ & $\begin{array}{c}77 \cdot 6 \\
100 \cdot 8 \\
-\end{array}$ & $\begin{array}{l}91 \cdot 3 \\
72 \cdot 8 \\
92 \cdot 9\end{array}$ & $\begin{array}{l}66 \cdot 9 \\
=\end{array}$ & $\begin{array}{c}63 \cdot 4 \\
105 \cdot 7 \\
-\end{array}$ & $\begin{array}{r}132 \cdot 8 \\
78.4 \\
104.8\end{array}$ \\
\hline 30 & $\begin{array}{l}\text { Benign } \\
\text { Tumours } \\
\text { and } \\
\text { Tumours } \\
\text { of Unde- } \\
\text { termined } \\
\text { Nature }\end{array}$ & $\begin{array}{l}1881 \\
1891 \\
1901\end{array}$ & $\begin{array}{l}98 \cdot 4 \\
=\end{array}$ & $\begin{array}{l}86.7 \\
90 \cdot 7 \\
-\end{array}$ & $\begin{array}{l}115 \cdot 6 \\
106 \cdot 3 \\
125 \cdot 0\end{array}$ & $\begin{array}{l}116 \cdot 4 \\
-\end{array}$ & $\begin{array}{l}70 \cdot 8 \\
58 \cdot 5 \\
-\end{array}$ & $\begin{array}{r}102.0 \\
79.6 \\
38.8\end{array}$ \\
\hline 31 & $\begin{array}{l}\text { Leukaemia } \\
\text { (All } \\
\text { Types) }\end{array}$ & \begin{tabular}{|l|}
1881 \\
1891 \\
1901
\end{tabular} & $\begin{array}{c}135 \cdot 1 \\
=\end{array}$ & $\begin{array}{c}190 \cdot 5 \\
314 \cdot 3 \\
-\end{array}$ & $\begin{array}{l}135.0 \\
205.0 \\
270.0\end{array}$ & $\begin{array}{c}232 \cdot 2 \\
二\end{array}$ & $\begin{array}{c}156 \cdot 4 \\
251 \cdot 3 \\
-\end{array}$ & $\begin{array}{l}123 \cdot 8 \\
161 \cdot 9 \\
238 \cdot 1\end{array}$ \\
\hline 32 & $\begin{array}{c}\text { Hodgkin's } \\
\text { Disease }\end{array}$ & $\begin{array}{l}1881 \\
1891 \\
1901\end{array}$ & $\begin{array}{c}123 \cdot 7 \\
-\end{array}$ & $\begin{array}{c}121 \cdot 2 \\
118 \cdot 2 \\
-\end{array}$ & $\begin{array}{l}135 \cdot 0 \\
130 \cdot 0 \\
175 \cdot 0\end{array}$ & ${ }^{156 \cdot 3}$ & $\begin{array}{c}105 \cdot 3 \\
142 \cdot 1 \\
-\end{array}$ & $\begin{array}{l}109 \cdot 1 \\
145 \cdot 5 \\
127 \cdot 3\end{array}$ \\
\hline
\end{tabular}

